\title{
Euroscepticism, Europhobia and Eurocriticism
}

The Radical Parties of the Right and Left

vis-à-vis the European Union

Cesáreo Rodríguez-Aguilera de Prat

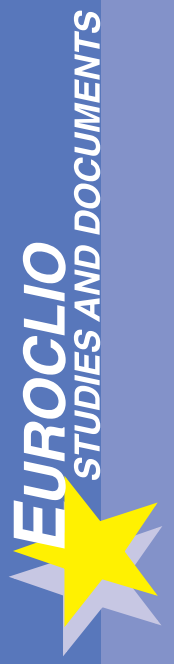


Euroscepticism has become a generic catch-all term that is not always useful in capturing the nuances of the different types of political opposition to the current process of European integration. This book analyses in detail the electoral manifestos and programmes presented by twenty-two parties during the European Parliamentary elections in 2009. The research indicates that radical right-wing parties usually have Europhobic impulses - their rejection being not only of methods, but also of principles. In contrast, radical left-wing parties are, in theory, favourable to European integration, but dispute the direction currently imposed by the EU authorities.

Cesáreo Rodríguez-Aguilera de Prat is Professor of Political Science at the University of Barcelona. He is a Doctor of Law and holds a degree in Contemporary History. His principal research interests are in comparative politics and, more specifically, European comparative politics. Within this field, his main focus is political parties. He has published numerous books and articles on these subjects and has worked as a visiting researcher in research centres and universities in Rome, Turin, Milan, Florence, Paris, Lyon, London, Edinburgh, Brussels and Mannheim.

\section{P.I.E. Peter Lang}

Brussels 




\title{
EUROSCEPTICISM, EUROPHOBIA AND EUROCRITICISM
}

\author{
THE RADICAL PARTIES \\ OF THE RIGHT AND LEFT \\ VIS-Ä-VIS THE EUROPEAN UNION
}

\author{
P.I.E. Peter Lang
}

Bruxelles · Bern • Berlin · Frankfurt am Main · New York · Oxford · Wien 
EUROCLIO is a scientific and editorial project, a network of research institutions and researchers, and an ideas forum. EUROCLIO as an editorial project consists of two aspects: the first concerns studies and documents, the second concerns tools. Both are aimed at making the results of research more accessible, and also at opening up paths through the history of European construction/integration/unification.

The EUROCLIO series meets a dual objective:

- to provide reference tools for research,

- to provide a platform for this research in terms of the publication of results.

The series thus consists of two sub-series that satisfy these requirements: the STUDIES AND DOCUMENTS series and the REFERENCES series. These two series are aimed at general libraries and/or university history departments, teachers and researchers, and in certain cases, specific professional circles.

The STUDIES AND DOCUMENTS series consists of monographs, collections of articles, conference proceedings, and collections of texts with notes for teaching purposes.

The REFERENCES series consists of bibliographies, guides and other tools. It thus contributes to the creation of a database making up a "Permanent catalogue of sources and bibliographies on European construction".

Edited by

Éric BussIÈRE, Université de Paris-Sorbonne (France), Michel DumOulin, Louvain-la-Neuve (Belgique), \& Antonio VARSORI, Universitá degli Studi di Padova (Italia) 


\title{
EUROSCEPTICISM, EUROPHOBIA AND EUROCRITICISM
}

\author{
THE RADICAL PARTIES \\ OF THE RIGHT AND LEFT \\ VIS-Ä-VIS THE EUROPEAN UNION
}

Cesáreo RODRÍGUEZ-AGUILERA DE PRAT

Euroclio No. 75 


\section{Bibliographic Information published by the Deutsche Nationalbibliothek}

The Deutsche Nationalbibliothek lists this publication in the Deutsche Nationalbibliografie; detailed bibliographic data is available in the internet at http://dnb.d-nb.de.

Library of Congress Cataloging-in-Publication Data A CIP catalog record for this book has been applied for at the Library of Congress.

An electronic version of this book is freely available, thanks to the support of libraries working with Knowledge Unlatched. KU is a collaborative initiative designed to make high quality books Open Access for the public good.

More information about the initiative and links to the Open Access version can be found at www.knowledgeunlatched.org

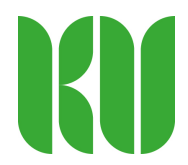

This book was originally published in Spanish by Huygens Editorial, Barcelona, 2012.

Translated to English by John Marten Barnard.

$\mathrm{D} / 2013 / 5678 / 22$

ISSN 0944-2294 • ISBN 978-2-87574-041-0 (Print)

E-ISBN 978-3-0352-6347-3 (E-PDF) • DOI 10.3726/978-3-0352-6347-3

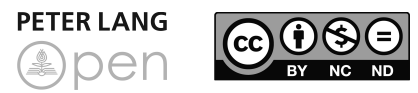

Open Access: This work is licensed under a Creative Commons Attribution NonCommercial NoDerivatives 4.0 unported license. To view a copy of this license, visit https://creativecommons.org/licenses/by-nc-nd/4.0/

This publication has been peer reviewed.

(C) Cesáreo Rodríguez-Aguilera de Prat, 2013

Peter Lang S.A.

International Academic Publishers

Brussels

www.peterlang.com 


\section{Table of Contents}

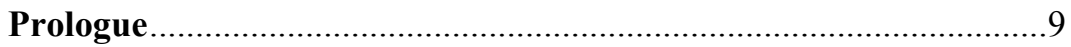

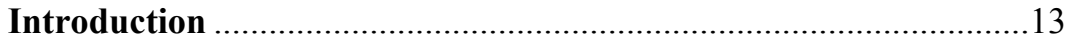

CHAPTER I.

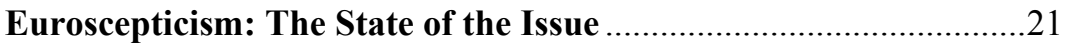

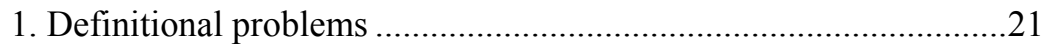

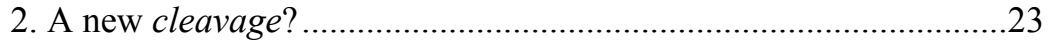

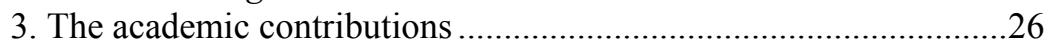

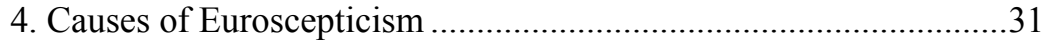

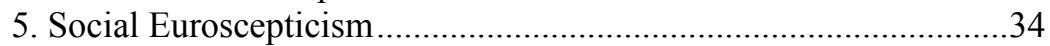

6. Political parties and Euroscepticism ................................................38

7. Ideology and strategy of the radical parties ....................................42

CHAPITRE II.

Background of Parties and their Impact on the 2009 Elections ......49

1. Traditional positions of the parties...................................................49

2. The elections to the European Parliament of 2009 .......................... 70

\section{CHAPITRE III.}

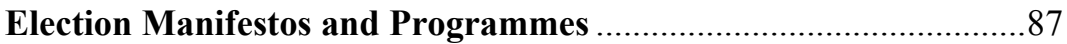

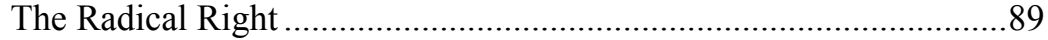

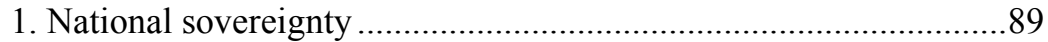

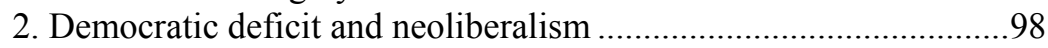

3. The balance of radical right parties ................................................ 103

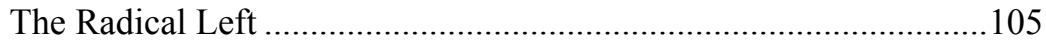

1. The rejection of neoliberal Europe...................................................105

2. The democratic deficit and national sovereignty .........................112

3. The balance of radical left parties ..................................................121

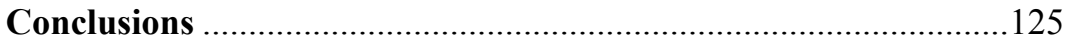

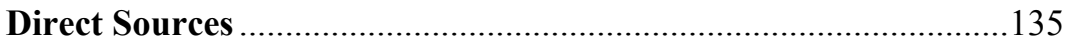

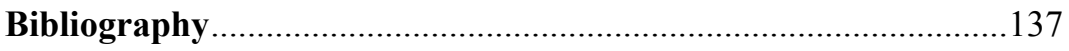

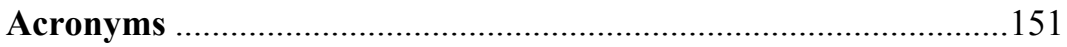





\section{Prologue}

It is a pleasure and honour to preface this book by Cesareo Rodríguez-Aguilera which you are now reading. Professor RodríguezAguilera, Professor of Political Science at Barcelona University, is a first class reference in the study of comparative politics in our country and this book does nothing but confirm this. This work makes an extremely significant contribution to our understanding of the phenomenon called "Euroscepticism" for at least three important reasons.

It does this, firstly, at a critical time for European integration, when the process of integration is going through one of its deepest crises, a crisis, no doubt, with such existential overtones that its survival is in question. It is well known, what was at first was a peripheral shadow in the system, British euroscepticism in the early 1990s, introduced and encouraged by Margaret Thatcher in the UK, ended up spreading to continental Europe. The Maastricht Treaty, with the victory of "no" in Denmark and the narrow victory of the "yes" in France marked a turning point in European integration. Although the EU believed in extricating itself from that first encounter between elites and electorates, the failed referenda in France and the Netherlands in 2005 not only threw the draft European Constitution overboard but, as noted by Professor RodríguezAguilera, European integration suffered a fracture (a cleavage) that since then has run transversely across European policy. The so-called "permissive consensus" by which the construction of Europe was governed during its first fifty years of history was swept from the stage, leaving the European Union to face a very dangerous spiral. It is increasingly difficult for the EU to legitimise itself through effectiveness, as "losers" or "victims" have appeared that call into question the official narrative presented by the EU as a process where everyone always wins. Nor can it completely legitimatise itself with its procedures because ultimately, democracy continues to reside at the national level and neither the public nor the politicians have wanted or have known how to democratise the EU (hence the poor results of the elections to the European Parliament and the paradoxical emergence of eurosceptical parties within the European Parliament itself). Nor, in the final instance, can it legitimise itself through identity, because precisely European integration has not only failed to create the support for identity it needs to survive, but, as this book shows, is perceived by some as a threat, not as a guarantee of these identities. So, Euroscepticism is here to stay - we 
must live with it, it becomes essential to understand it better, it is what this book shows us and which, at the same time, constitutes its second substantial contribution.

This second contribution comes from the fact that both the term and the phenomenon of Euroscepticism are, despite their validity and current visibility, complex realities, hard to handle, difficult to capture and explain. What better claim for the task of social scientist and the utility of political science than the commitment Professor Rodríguez-Aguilera offers us here in observing reality, stopping the clock, reviewing, analysing problems, breaking down complexity, understanding the relevant variables that explain a problem, developing concepts that account for the observed and building explanations that account for that reality. This is a rigorous, well structured, intensive yet extensive piece of work, whose ambition is to cover the entire scope of Euroscepticism, from right to left, in all its rich and varied hues. Euroscepticism is a polysemous term, almost a cliché or catch-all concept under which are grouped, without much rhyme or rigour, in a superficial analysis phenomena that seem alike, but which reveal themselves to be different when examined in more depth. Here the work of Professor RodríguezAguilera seems like that of an entomologist, who patiently dissects the 22 objects of study (in this case, eurosceptical parties) to offer a taxonomy that allows us to understand what we mean when we speak about Euroscepticism. It does this, moreover, despite the difficulty of obtaining the data underpinning his study because, as he surprisedly points out, parties pay so little attention to their manifestos, that are supposedly their contract with voters; that they do not even bother to save them, send them to the citizens who request them or deposit them in the library of the European Parliament.

The third reason why the contribution of this book strikes me as very relevant relates to the specifically Spanish context in which it is published. Spain is a country with a long tradition of European thought. For historical reasons that are well known to readers (Francoism and the transition to democracy), national and European interests have merged in such a way that it has generally been impossible to separate and distinguish between them. From Spain, the criticism of the alleged "democratic deficit" of the EU has always been misunderstood and mismatched, partly with good reason, because certainly our country was almost certainly more democratic, in some ways less democratic, merely because of being a member of the EU. This structural inability to understand the EU as a threat to identity, prosperity and democracy is what led to Spain, of all the countries of southern Europe, being the only one where the consensus on accession was total. While in Portugal or Greece communist parties were always critical of European integration, 
which for them already felt like a product of commercial and financial capitalism, that is, an advance of what later would be called "globalisation", in Spain there was not only unanimity, but unanimism, i.e. assent to Europe became the unquestioned ideology. Not surprisingly, and as proof, the Spanish United Left party (Izquierda Unida) broke apart in 1991-1992 over the decision on whether to vote in favour or abstain in the parliamentary vote on the Maastricht Treaty, leaving a leading group of leaders, the PCE and the coalition at that time, standing alone. From the sidelines, it was not without its logic that a Communist Party would vote against a monetary union such as that established in Maastricht - it would also happen with regard to the European Constitution, where again the radical Spanish left would take a critical stance, Spanish Euroesceptics never took such as position. As Professor Rodríguez-Aguilera rightly asserts, these facts fully justify the need to design categories that help us understand not only the phenomenon of Euroscepticism but its nuances and in many cases, the enormous differences between parties and attitudes that, out of laziness or a need for simplification, are usually grouped under the same conceptual umbrella.

Therein lies ultimately the last and most significant merit of this book. To the timely, analytical and contextual relevance of his research, the relevance of his results must be added. The exhaustive review of the existing literature that Professor Rodríguez-Aguilera carries out is helpful, though also extremely demoralising at first sight. Eurocritics, Europhobes, Eurorrealists, Europragmatics, gradualists, rejectors, revisionists, minimalists, reformers, maximalist Euroenthusiasts, Eurooptimists, Europessimists, "hard stance", "soft stance". Having overcome the initial instinct to throw in the towel, Professor RodríguezAguilera gets down to work and using the scalpel of the political scientist, gives us the keys to reconstruct and understand the material. For this he analyses the different dimensions and demands on which these parties pronounce their Euroscepticism: left-right, more or less integration, sovereignty, identity, immigration, globalisation.

His conclusions are clear and far reaching. Firstly in taxonomic terms, his findings are robust while elegant and leave us with a much more accurate route map than we had when we started reading. As he indicates, we can even see the horizon, at least in analytic or academic terms, where we could dispense with the term "Eurosceptic" having then found substantially higher analytical alternatives.

Second, in substantive terms or content, his conclusions allow us to separate right-wing Euroscepticism very precisely, clearly more directly anti-European and focused predominantly on immigration (i.e., 
identity), from that of the left, which maintains an integrative predisposition, but is openly critical of the economic design and orientation (of neoliberal persuasion) of the European project. They clearly share, with different nuances, democratic and sovereigntist concerns, but by finalising substantially different understandings of the meaning and purpose both of sovereignty and democracy, this rhetorical mechanism structured around the concepts of sovereignty and democratic deficit is not solid enough to force a common stance.

Beyond the differences and similarities between them, this distinction between "Europhobes" on the radical right and "positive Eurosceptics" on the radical left is very useful not only in itself but because it allows us to understand how this fracture is configured in Europe when we add the two remaining categories: on the one hand, the "Europhiles" parties represented by the parties of center-right and center-left, supporting European integration today which are generally in line with both the concept of integration and its main results and secondly, the "negative Eurosceptics" or conservative and agrarian parties, that reject the principle of integration but live with its results in a pragmatic way. So, with the author as a guide and with rigour and elegance, readers can immerse themselves in the forest of complexity that the phenomenon of Euroscepticism represents, coming out the other side with a much clearer picture than at the outset. It is for this reason, returning to the beginning of this prologue, that we must thank Professor RodríguezAguilera and congratulate his work in giving us a much needed contribution to the study of Euroscepticism.

José Ignacio Torreblanca

Professor of Political Science of UNED

Member of the European Council on Foreign Relations 


\section{Introduction}

The initial idea for this book came about due to a certain personal dissatisfaction that made me see a systematic categorisation of all the parties that criticise the current EU as "Eurosceptic", with no differences and no regard to their ideology. The term is often used as a catch-all concept not only in the media, but also in academic forums (in this case, with nuances) and this led me to investigate the issue in depth, especially bearing in mind that my main object of scientific interest is precisely political parties in their European projection. In analysing the types of criticism of the radical right and left in the EU today, apart from some objective coincidences, I quickly discovered the different proposals of each group (to reject further integration in the first case and advocate another type of integration in the second, always with some exceptions) and that is what prompted me to start this research three years ago, now presented here in completed form.

The first chapter is not intended to provide new types or unpublished empirical contributions, but to review and organise the vast material available today with regard to the issue. The objective is to provide the main descriptive and analytical elements of the eurosceptical phenomenon in its various dimensions in a systematic way, both conceptual and empirical. In this sense, this overview addresses the problems of a multi-purpose term that semantically includes two possible dissimilar attitudes: complete rejection or specific reservation.

This book analyses the more significant theoretical and empirical contributions made by qualified specialists in the study of Euroscepticism. The following outlines the root causes of the same, both in its social and partisan dimension: more specifically it looks at the main instrumental socio-economic theories, the focus on political legitimacy and linkage to national identity. Since this research focuses on parties, we especially look in depth at this area with regard to the appraisals and attitudes the groups of left and right have had.

At the outset of the second chapter, we analyse the recent historical background of the parties under research to highlight the main items of criticism of the EU, both deducible from their programme documents and their political action. It reviews the main arguments of both ideological groups of parties and their internal variations in the three principal selected critical dimensions: national sovereignty / democracy 
deficit / neoliberalism (higher to lower in the case of the radical right and reverse for that of the radical left). Following on from this, there is a specific presentation of the criticisms these parties make in these areas, with occasional collateral reference to other similar formations not included in this research. I should point out that, in this section of the second chapter, the parties are usually grouped by some kind of affinity (on the radical right: classic extreme/postmodern populist; on the radical left: orthodox communist/postcommunist). The characteristics of the EP elections of 2009 are then set out, given that the election manifestos analysed correspond exclusively to this election and a cursory study of the national context of the campaign and the results of this type of party in the countries selected. In this case, the analysis of election results is done according to the alphabetical order of each country.

The third and final chapter deals with the comparative and transversal analysis of the election manifestos of political parties selected - which are the most representative of both ideological groups - in the three important dimensions indicated and the exposition of the different ways for right and left, given the different intensity that they both attribute to the above factors, have been organised. Therefore the ideological and programmatic centrality of the doctrine of national sovereignty in every one of the radical right parties selected is brought into focus. In this sense, it highlights the clear rejection of the possible federalisation of EU policy, and denial in assuming a multicultural society, hence the xenophobia against non-EU immigration or exclusion of Turkey as a possible member of the collective. On the other hand, the main factor of EU criticism for the radical left focuses on the objection to its neoliberal socioeconomic policies exclusively favouring big business and detrimental to workers and people in general. The last dimension considered is the EU's "democratic deficit" where the objective coincidence of criticism of both ideological groups of parties is high. This chapter does not follow the alphabetical order of countries or parties for the exposition of these parts (political/economic/cultural) of their respective manifestos, but of the electoral and parliamentary strength of each party in their respective state or territory (in the case of subnational parties), from highest to lowest. For operational reasons only the parties EFD and GUE/NGL integrated into EP eurogroups have been considered, together with some outstanding members of the radical right who are in the EP as "unregistered" entities. So well known eurosceptical parties of the conservative right (ERC) or a few of the green left (present in the EFA) are not included in this research.

Of the 27 current EU states, I have selected 17 of the 22 theoretically possible for study (in the remaining five, radical parties of the right or left of the two researched eurogroups did not achieve representation). I 
had to finally renounce five of which some had indeed achieved representation to the EP because it was completely impossible to obtain their manifestos, despite repeated requests on varied occasions on a very personal basis, but otherwise, their absence is not that important since these concern (almost exclusively) very small parties that achieved a minimal presence. So in the seventeen countries finally chosen the picture is as follows: radical right parties only achieved representation in a total of eleven, radical left parties in only nine and both ideological groups in only three.

Table $\mathbf{1}^{1}$

\begin{tabular}{|l|c|c|}
\hline Country & Radical Right & Radical Left \\
\hline Germany & - & DL \\
\hline Austria & FPÖ & - \\
\hline Belgium & VB & - \\
\hline Bulgaria & NSA & - \\
\hline Czech Republic & - & KSČM \\
\hline Cyprus & - & AKEL \\
\hline Denmark & DF & - \\
\hline Spain & - & IU \\
\hline France & FN & FG \\
\hline Greece & LAOS & KKE / SYRIZA \\
\hline Holland & PVV & - \\
\hline Hungary & JMM & - \\
\hline Italy & LN & - \\
\hline Portugal & - & BE / CDU-PCP \\
\hline United Kingdom & UKIP & SF \\
\hline Romania & PRM & VP \\
\hline Sweden & - & \\
\hline
\end{tabular}

I would like to point out that it is not in any way the objective of this research to concern myself with defining what a "radical" party is: I assume the elaborate and consolidated conceptualisations of specialists such as Mudde, Ignazi and Perrineau for the radical right and Backes and Moreau, Dunphy, De Waele and Seiler with regards to the radical left. Although, in general, I analysed only the specific programmes that the 22 selected parties presented for the EP elections of 2009, in some cases I had to resort to a complimentary documentation: this is the case of LAOS that produced two separate texts on its proposed policy on this issue and of the $\mathrm{VB}$, given that the European and regional elections

See the list of acronyms at the end of the book. 
coincided in Flanders and their European positions were reflected in two different texts.

Academic literature justifying recourse to the study of parties' electoral manifestos is already abundant and I personally had the opportunity to study this matter thoroughly in my book Political Parties and European Integration, ICPS, Barcelona, 2008 (English version by PIE Peter Lang, Brussels, 2009), it is however worth reiterating that these are official documents, representative of the whole party and also public. In the chosen manifestos of 2009 several common elements were found: 1) overwhelming dominance of national issues, 2) absence of real transnational coordination with homologues from other countries and 3 ) few concrete commitments and numerous general statements (see Braun, 2010; Sigalas, 2010).

The use of computer programmes in the analysis of these texts (such as "Atlas-ti" or the PIREDU of the Manifesto Group Research of the Mann'heimer Zentrum für Europäische Sozialforschung / MZES) were rejected for various reasons: 1) for the non-coincidence of items of the same with the ones I have used, 2) because the coding these systems use do not always coincide, 3 ) for the complexity derived from so many different languages (not all can be processed and to translate all the programmes into English would imply an extraordinary increase in costing for the project) and 4) mainly because these techniques, in my view, do not contribute anything especially relevant to the interpretation, beyond providing some quantitative indicators that are often insignificant. In sum, these forms of text analysis, though having produced some interesting results (in particular those of the Comparative Manifesto Research Group led by Budge) have received numerous profound criticisms for having a rather low reliability (in this regard, it is of interest to compare the positions of specialists such as Benoit, Garry, Laver, Martin and Vanberg). Finally, I would like to mention that I do not cite specific pages of manifestos because the translations have changed their format (sometimes considerably, the case of illustrated texts) and therefore the number of pages is not the same and do not match the original.

The collection all 22 electoral manifestos has been an extraordinarily difficult and lengthy task, the whole process requiring frequent and repeated contacts of various kinds and nearly six months' work because none were present on the party websites (September 2010 to February 2011). To begin with, I sent emails to all the party headquarters, but the result could not have been be more disappointing: of the 22 parties, only six answered and four of these could not provide any manifesto at all (only the LN and IU sent theirs back to me). The DF, the FPÖ and the 
FN limited themselves to sending me a prerecorded bureaucratic response that referred to their respective web pages which, as I have explained, no longer contained the election manifestos of 2009. For its part, the Danish Folkebevaegelsen mod EU party clarified that no manifesto had been presented as they had lent their support to an independant candidate.

With this option exhausted, I chose to speak directly to each and every one of the MEPs of the 22 parties being researched. The initial result was even more disappointing because, in the first instance, none deigned to answer me. It took a new batch of emails, spaced over time to start having some results: in the second instance, a representative of the Bulgarian NSA party announced that he would send me their programme "soon", something that never happened despite me sending him two reminders of his promise. Only after the third round of emails I received the manifestos of the BE, the CDU-PCP, the VP and the DF.

In summary, neither the parties nor MEPs In general worked (which is still somewhat incomprehensible from the standpoint of public relations) for the compilation phase of the texts, so it was more practical in the end to go to academic colleagues. Although those I now mention did not manage to obtain the documents I requested, I know they made great efforts in this and so would now like to offer my gratitude: William Genieys (University of Montpellier), Pierre Bon (University of Pau et Pais de l'Adour) Nonna Maier (CEVIPOF), Pascal Perrineau (CEVIPOF), David Mc Crone (University of Edinburgh), Lieven De Winter (University of Leuven), Blanca Vilà (Universitat Autònoma de Barcelona) and Suzana Tavares (University of Coimbra). However, Montserrat Baras (UAB), Pere Joan Plaza Universidad Carlos III), Josep Ma Reniu (Universitat de Barcelona) and, especially, Ignasi Pérez (IES Abroad Barcelona/University of Chicago) were absolutely decisive with their contacts and help. Montserrat Baras gave me the contacts of Eva Poptcheva (she obtained the NSA and JMM manifestos), Patricia Correa (who, in turn, contacted Eva Finkova who, thanks to her colleague Ladislav Mrklas at the University of Prague, was able to get the KSČM programme, and finally, that of the FN, surprisingly the most difficult to obtain). Joan Pere Plaza obtained the LAOS and the PRM manifestos and Josep Ma Reniu obtained the programme of the SF and VB. At the same time, Ignasi Pérez, through Kalispera Thanos, obtained the manifestos of the KKE, SYRIZA and AKEL and directly that of the FG, the PVV and UKIP. In contrast, I received no response from the MZES (where I had occasion to conduct research in May 2008), a centre specialised specifically in the study of European election manifestos because, despite my repeated emails, this time I received no institutional help whatsoever from this centre. However, a colleague of the same - 
currently on secondment at the University of Vienna - was very helpful and I obtained the programmes for the DL and FPÖ: I am therefore very grateful to Wolfgang Müller.

Let me also express my heartfelt appreciation to Juan Crespo and Lorenzo Mannelli, both in the service of the EP in Brussels, for having provided me all the addresses for the euro-deputies and direct support given to me in the seat of that institution in June 2011 where I was able to collect more materials useful to conclude this research. In this regard, I extend special thanks to the library that the MEP Raul Romeva gave me access, as well as the efficient efforts of Pilar d'Orey. In any case, it is still somewhat surprising that the Library of the European Parliament does not have the electoral manifestos of the parties present in the institution: it is true that these are not official documents of the same, but it would be very easy to request that MEPs to deposit a copy of their programs in the centre, which would be an extraordinary help for the task of researchers. Finally, I must point out that, in order to improve agility, I always asked for the manifestos in their respective original languages as I already knew that it would be difficult to have available versions translated into English. This means that I had to order several translations, in many cases minority languages, which increased expense and delayed the whole process. As a speaker of Castilian, English, French, Italian and Portuguese, I had no problems with the manifestos written in these languages, in fact, I found to my surprise that two parties with other languages had sent me their texts in English (AKEL and KKE). I want to thank the German translations from German (DL FPÖ) by Raul Hernandez, from Bulgarian (NSA) by Tsarimir Alexandrov, from Czech (KSČM) by Lenka Skalosova, from Danish (DF) by Boersting Mette, from Greek (LAOS, SYRIZA) by Stavrinidou Eleni, from Dutch (PVV, VB) by Caspar Visser, from Hungarian (JMM) by Kristine Farkas, from Romanian (MRP) by Teica Tatiana and from Swedish (VP) by Agnes Von Anoint.

Finally, I would also like to mention other people who, in one way or another, also provided assistance in this long and complicated process: Òscar Barbera (University of Valencia), Astrid Barrio (University of Valencia), Juan Rodriguez (University of Valencia), Esther Martin (University of Barcelona), Ana Sanchez (University of Barcelona), Montserrat Morante (University of Barcelona) and Ruth Ferrero (Complutense University). I want to pay special tribute to Mariano Torcal (Pompeu Fabra University) since he very kindly allowed me to consult the manuscript of the book co-edited with Joan Font on elections to the European Parliament in 2009 - prior to publication. I can not conclude without mentioning that this study is linked to the Grup de Recerca sobre Elits $i$ Partits (Research Group on Parties and Elites) 
(GREP.SGR 2009-1290) and to the project coordinated by Montserrat Baras "The effects of decentralisation on political parties: human base,

organisation and alliances. Spain in Comparative Perspective" through which I would not have received financial support for the translations of some election manifestos.

Barcelona, November 2011. 



\section{CHAPTER I}

\section{Euroscepticism: The State of the Issue}

\section{Definitional problems}

The term Eurosceptic appeared in the British press in the mid-1980s to qualify the reservations and criticisms that the Premier Margaret Thatcher had of the European Community. Since then its usage has been synonymic for anti-common market and, more precisely, equivalent to all the intense, direct criticism of the process of European integration. This was reinforced after Thatcher's famous speech at the College of Europe in Bruges (22 September 1988), in full opposition of an alleged "centralisation" of Brussels, the "all embracing nature" of EU bureaucracy and the risk of moving towards a European super-state ${ }^{1}$. Although Eurosceptiscism appeared as a distinctively British phenomenon, it became generalised - in varying degrees - in other community members and this has helped to reinforce the fortunes of the term, especially since it has become a permanent structural datum of the European political landscape. It has therefore overcome de facto the classic thesis of British exceptionalism with regard to the EU from the moment that the attitudes of reservation and/or rejection were significantly manifested in the vast majority of states.

Although the term Eurosceptic has a journalistic origin, not an academic one, European policy specialists have eagerly taken to providing it with a theoretical and empirical operating status. This expression, as well as other diverse terms such as Europhobia, Eurocyinism or Europessimism are - at the outset - media labels that only very imperfectly identify ideological values and/or strategies of political elites and where appropriate, of public opinion. All were journalistic indicators rather than genuine, formal concepts of political

The Oxford English Dictionary defines a Eurosceptic as "a person who is not enthusiastic about increasing the powers of the European Union". The dictionary cites an article in The Times, June 1986 as the first to use the term, although Spiering detected an earlier reference, in November 1985, in the same newspaper in referring to an "anti-common market" position. Vid. Harmsen, Spiering, 2004, p. 15-16; Harmsen, 2005, p. 280; Hooghe, Marks, 2007, p. 120; Sczerbiak, Taggart, 2008, II b, p. 261; Leconte, 2010, p. 3 and 12. 
theory, among other factors because we are not dealing with perfectly defined and closed categories. However, the progressive accumulation of a broad background of academic research has continued to refine the concept. Euroscepticism is often used synonymously to define some kind of opposition, as a practical response to the development of the EU: "expressing the idea of a contingent or qualified opposition (...) the process of European integration". . One of the greater conceptual and operational difficulties is to draw the boundary which permits certain types of criticism of the EU by Euroesceptics, but not by others. This means that Euroscepticism implies a continuum that ranges from serious doubts to clear rejections.

Besides the question of gradations, the motivations are not always the same given that - sometimes - economic ones predominate (if the expected material benefits do not materialise or are not enough), political ones at other times (fear of loss of national sovereignty, mistrust in the EU institutions for their opacity). In short, at the outset it seems quite clear that anyone who is against the EMU could be described as eurosceptical, but not the one which - for example - only objects to the PPC. Now we are becoming more precise, it should be noted that the term has more congruence applied to those with a strict view of European intergovernmental cooperation and a rejection of the supranational delegation of sovereign State responsibilities ${ }^{3}$.

In the mass media and even in some academic literature, the term Euroscepticism is used as a catch-all, multi-purpose, hybrid, ambiguous and generic term as it includes different attitudes to the EU. Indeed, sometimes it is used as a synonym for any kind of opposition to the EU, at other times as a reserve against certain relevant EU policies. In fact, separate variants need to be clarified as the principled opposition to the current EU can not be grouped together (without forgetting that the ideological perspectives can be very different in this respect) or the criticism of certain EU decisions, important as they are. Consequently, the use of the term Euroscepticism can mean both outright rejection and permanent doubts about the direction the current EU is taking and this is what makes the concept something rather vague and all-encompassing, requiring an effort of conceptual clarification and analytical, empirical operability ${ }^{4}$.

2 Taggart, 1998, p. 366; Tierski, 2001, p. 3 and 305; Rovny, 2004, p. 31; Krouwel, Abts, 2007, p. 254-255 and 268.

3 Hooghe, Marks, 2007, p. 120; Leconte, 2010, p. 6 and 8.

4 Both the Dictionary of the Royal Spanish Academy of Language and that of Maria Moliner include two different semantic meanings in the term "Scepticism": first, doubts and reservations, and other negation and opposition. On its application to the 
In view of this, it seems clear that to pigeonhole any opposition to the current EU with the convenient term of Euroscepticism is not very illuminating because of its lack of nuance. Ultranationalist Europhobia and criticism of the current EU for being insufficiently supranational are not comparable, for example. We can neither assimilate the advocation of the abandonment and/or dismantling of the EU nor demand a lot more integration than already exists. Naturally the "central block" parties that support the ongoing process practically without reservation (the three main ideological groups of the EP: conservative, socialist and liberal) are primarily interested in denouncing all opposition as eurosceptical, whether this is ideological or for whatever goals they have, which creates a confusing amalgamation of the different types of criticism of European integration. In fact, it is not very clarifying to mix negative opposition (mostly on the radical right) with positive (the majority of which is on the radical left), but if any background criticism to EU policies involves these being typecast as eurosceptical, then the term loses conceptual value for academic analysis. On the one hand, not all Euroscepticism always implies a negative attitude, and other, more differentiation is needed to develop more sophisticated analytical typologies ${ }^{5}$.

\section{A new cleavage?}

Euroscepticism is not just a phenomenon of certain elites, some mass media or voters who protest: it is a more complex phenomenon that interacts with all these elements in certain contexts. From being initially a marginal phenomenon, it has grown steadily since the 1990s and has become an element of undoubted impact on the process of European integration. The political and social boom of Euroscepticism is related to many factors: among others, a weak feeling of European community, popular distrust of the political representatives of the establishment and the economic crisis reinforcing the tendency towards protectionist measures. The disaffection of significant social sectors, the demagoguery of some clever populist politicians and the increasing difficulty of the pro-EU elite in convincing public opinion of their conduct explain for example - the defeats of various national governments on referenda held on European issues ${ }^{6}$.

EU: Harmsen, Spiering, 2004, p. 33; Lubbers, Scheepers, 2005, p. 229; Neumayer, 2008, p. 136; Sczerbiak, Taggart, 2008, Ia, p. 7 and II b, p. 240 and 253; De Vries, Edwards, 2009, p. 10.

5 Taggart, 1998, p. 366. Krouwel, Abts, 2007, p. 268; Neumayer, 2008, p. 155.

6 Eichenberg, Dalton, 2007, p. 140; Hooghe, Marks, 2007, p. 119; Krouwel, Abts, 2007, p. 252-253; Wessels, 2007, p. 288 y 290-291. Leconte, 2010, p. 2-3, 9 and 10. 
It is a somewhat debatable question as to whether European integration is a new cleavage that - in principle - sets the losers of globalisation against the winners, though this dichotomy presents some relevant exceptions (the United Kingdom as a country is not a "loser" in the EU, however, it is largely eurosceptical). If European integration were an integral cleavage, it should have a strong internal projection in domestic politics, but this is rarely the case because the competition between national parties in each state ignores, to a greater extent, the eurosceptical issue. In a restricted sense it has been indicated that criticism of European integration has a strategic reach and so would not become a true cleavage, but in an extensive sense it could considered as such as it affects both the confrontation of national sovereignty versus supranationality and the division right/left. Therefore, European integration itself can be considered broadly as a cleavage because it focuses on a redefinition of all those being found in the foreign policy of some states and reflects the emergence of a new dimension in political competition. However, it is true that the European issue is always instrumental and dependent on the domestic agenda, given that community affairs - in general - have little direct relevance to national political life ${ }^{7}$.

From the mid-1950s to the late 1980s Euroscepticism was clearly marginal, initiating the change of social and political perception from the SEA and, above all, the TEU, which ended the era of "permissive consensus" in the construction of Europe. However, it remains somewhat schematic to say that before the 1990s there was an almost total acceptance of any integrational advance and today a systematic opposition as the picture is more nuanced. For example, in the 1950s is true that $70 \%$ of Western European public opinion was in favour of European unification and only $10-15 \%$ against, but that half a century later, the percentages have changed relatively little so that $60-65 \%$ continues to support integration while the $15-20 \%$ opposes it, this without overlooking the different responses to economic integration (widely shared) and political integration (significantly lower) ${ }^{8}$. In any case, it is true that the intense debate on the EU Treaty showed a clear symptom of a gap between pro-integrationist elites and public opinion for the first time, both for economic reasons (negative evaluations of the cost-benefit calculation) and identity (very weak feelings for the European community and strong national roots) as well as political

7 Setter, 2002, p. 7-9; Sczerbiak, Taggart, 2008, Ia, p. 2; Steenberger, Scott, 2008, p. 165-195; Fuchs, Magni-Berton, Roger, 2009, p. 12-13, 15 y 20; Leconte, 2010, p. 37.

8 Gabel, 1998a, p. 112. The figures in Leconte, 2010, p. 44-45 and 162-165. 
criticism (the "democratic deficit" of the EU). This was because the EU Treaty implied a reconceptualisation of European integration and increased the powers of EU institutions, two elements not easily accepted by large sectors of national public opinion. With this, it was found that the greater European integrative process, the greater the rejection and the sources of friction - the advance of the process generated an increasing amount of discontent, sometimes channelled by some parties ${ }^{9}$.

The complex and contradictory process of European integration shows that the main contrast in this respect is in the continuum that ranges from sovereign nationalists to supranationalist Federalists and the analytical key lies in discriminating the different types of opposition that reflect reservations or hostility, both by sectors of the political elite and public opinion. From here, it is noted that Euroscepticism - in all its forms - is a transversal ideological phenomenon that crosses the left/right axis and is clearly present even within parties themselves. This means that although in most cases Euroscepticism is often associated with groups that cling to the myth of national sovereignty and are unwilling to cede more power (or even recover some or even all already ceded) to the EU, at other times formations that - in fact - are not antiintegracionist in principle, but understand an alternative construction of Europe, are tagged with this label, criticising the current process underway in considering it insufficient ${ }^{10}$.

The uncertainty of the European project is reflected in differing models used for understanding integration, one more supranational (linked historically to the Franco-German alliance), one more statist and economic (led by the British, followed by Scandinavian countries and several CEEC) and the mismatch of objectives, causing contradictions, setbacks and eventual paralysis. Economic crises and difficulties the EU has in addressing them, political conflicts and the nationalist tendency to withdrawal contributed to the rise of Euroscepticism as a general phenomenon of protest that affects several dimensions, some magnified by the radical right (national identity) and others by the radical left (the unequal elements of the market economy). This means that opposition to the EU takes different forms and also affects distinct elements, in such a way that variations are produced: 1) direct opposition to any kind of integration, 2) opposition to the current level achieved, considering it

9 Taggart, 1998, p. 364; Sitter, 2002, p. 5; Harmsen, Spiering, 2004, p. 17 and 25; Mc Laren, 2004, p. 895; Eichenberg, Dalton, 2007, p. 129 and 131; Hooghe, 2007, p. 5. Fuchs et al., 2008; De Vries, Edwards, 2009, p. 5-6; Trenz, Wilde, 2009, p. 1-2; Leconte, 2010, p. 167.

10 Taggart, 1998, p. 363; Sitter, 2002, p. 10; Sczerbiak, Taggart, 2008, I a, p. 9. 
excessive and 3) opposition to the current level, considering insufficient. To refine further: "All who oppose the EU are, in short, sceptics, but not all sceptics are opponents" - some groups raise objections to everything, while others raise objections to only some aspects of European integration $^{11}$.

\section{The academic contributions}

To measure attitudes (pro-integration / reservations / anti-integration) scholars have used various sources: party manifestos, statements from party leaders, votes of their representatives in the EP and opinion polls (the series of existing Euro-barometers are very abundant), among others. These are all being used in an attempt to combine both ideological and strategic variables, without overlooking some specific difficulties: at the theoretical level, the more internal complexity and variety of the types, the greater the difficulty verifying them operationally and at the empirical level, what has been relevant is the overcoming of the initial approach focused almost monothematically on questions formulated in terms of the parameter cost/benefit (the instrumental approach), to address other very relevant dimensions (the identity and the quality of democracy). So there are many factors under discussion: the impact of economic integration and the scope of community public policy, in politics, the strategic direction of the process and the performance of institutions and actors, in identity factors - the idea itself of the European community and the stage achieved. This all has obvious projection on the specific study of Euroscepticism that should evaluate not only its "magnitude" (quantitative criterion) but also its "motivation" (qualitative criterion) ${ }^{12}$.

The academic literature on Euroscepticism is already rich and of quality, although no "school" that imposes its views has emerged. Some contributions have focused on public opinion (Lubbers/Scheepers), others on the party elites (Kopeck, Mudde, Sczerbiak, Taggart) and some on the conceptual dimension (Flood, Tierski). The proliferation of non-coinciding concepts and classifications has generated significant scientific debate that has refined the theoretical level whilst perfecting empirical methods of evaluation and treatment of the data. All of this with the understanding that there are still problems in operationalising

11 Quoted from Taggart, 1998, p. 366; Eichenberg, Dalton, 2007, p. 139; Hooghe, Marks, 2007, p. 125; Fuchs, Magni-Berton, Roger, 2009, p. 21; Leconte, 2010, p. 7. 169 and 172.

12 Rovny, 2004, p. 38; Lubbers, Scheepers, 2005, p. 224; Krouwel, Abts, 2007, p. $255-$ 256 and 270; Wessels, 2007, p. 287-306; Neumayer, 2008, p. 137; Sczerbiak, Taggart, II a, p. 5 and II b, p. 239; Fuchs, Magni-Berton, Roger, 2009, p. 16; Kufer, 2009 , p. 40. 
some types whose explanatory power can be relative and this explains why the academic results have not produced a unanimous interpretation of the eurosceptical phenomenon.

It was Flood who provided the most comprehensive theoretical framework that includes six major categories with internal subcategories to cover the full potential range of positions relative to European integration. Although his contribution presents not insignificant difficulties in empirical application, it is relevant for its exhaustive conceptual character:

1) rejectionist:

1.1) as opposed to EU membership

1.2) opposition to participate in some of its basic policies

2) revisionist:

2.1) return to the state basic policies transferred

2.2) do so only with some very specific policies

3) minimalist:

3.1) accepted as the maximum current status quo for the entire community structure

3.2) only for some areas

4) gradualist:

4.1) supporting a greater integration for the whole

4.2) only for some areas

5) reformist: in favour of greater European commitment and a gradual increase in integration;

6) maximalist:

6.1) for maximum integration of the entire structure of the EU,

6.2) for certain areas ${ }^{13}$.

In this sense the Kopecky and Mudde scheme is more practical, which groups the four main variants from two dimensions, the attitude towards the principle of integration and to specific Community policies.

13 Flood, 2002. Based on this and other contributions, Perez provides a more simplified (and operative) table: 1) Europromotors (the "central block" of the political formations in favour of the current EU), 2) Euroesceptics (in this case, distinguishing between minimalist and revisionist) that propose a halt to the integration process and in some cases, a return of powers to the states, but not to dismantle the EU and intergovernmental economic cooperation, 3) Eurorepublicanists (they are - in his opinion - the critics of the current EU advocating a much more ambitious alternative), 4) or anti-Europeans who defend the Europhobes' abandonment and/or dismantling of the current EU. Perez, 2008, p. 92-94 and 115-117. 
With the integrationist principle, firstly, the divide between Europhiles (Euroenthusiasts) and Europhobes is clear, with an initial lack of nuance, that of the "agnostics" (Europragmatics). In practice in the Community the division includes Euro-optimists and Europessimists: the former believe that the current process of integration is right because there is really no other possibility (this does not stop them disagreeing with one or another specific EU policy) and the latter, who believe, in contrast, that the EU is not moving in the right direction in accordance with its historical premises. Both authors distinguish, therefore, parties that to a greater or lesser extent diffusely oppose the principle of integration (i.e. to cede sovereignty to supranational authorities) and those who specifically oppose either the extension of the ceded part or specific Community policies. From this point, the variants are grouped in four positions: 1) Euroenthusiasts (Europhiles and Euro-optimists), 2) Eurosceptics (Europhiles and Europessimists), 3) Eurorejectionists (Europhobes and Europessimists) and 4) Europragmatics (Europhobes and Euro-optimists). The first group supports the principle of integration and the way this is being done (the procedure), the second group are not against the principle, but are contrary to the procedure, considering it "excessive", the third opposes both the principle and the procedure and the fourth does not share the principle but accepts the acceptance of the procedure as inevitable.

Table 1

\begin{tabular}{|l|l|c|c|}
\cline { 3 - 4 } \multicolumn{2}{c|}{} & \multicolumn{2}{|c|}{ SUPPORT FOR THE PRINCIPLE } \\
\cline { 3 - 4 } \multicolumn{2}{c|}{$\begin{array}{l}\text { SUPPORT FOR } \\
\text { THE PROCEDURE }\end{array}$} & Europhiles & Europhobes \\
\cline { 3 - 4 } & Europessimists & Euro-enthusiasts & Europragmatics \\
\hline
\end{tabular}

Source: Kopecky, Mudde, 2002, p. 303.

The category of "Euroenthusiasts" may be too inclusive and generic as it does not quite capture the different types of acceptance of the EU, an area in which there is a high level of transversalism even within a group of parties, given - occasional - conflicting national interests. It is true that the parties of the center-right and center-left often coincide in both the principle and the current integrative procedure of the Community, but - for example - the differences between the French Gaullists and the Belgian Christian Democrats or between the British Labour Party and German Social Democracy on both dimensions are known. Kopecky and Mudde are aware of the fact and, consequently, distinguish within the Europhile field between integrationist and strictly economic policies. A nuance clear in theory, but in a particular concrete case this may cause some perplexity: in the second sense, Thatcher was 
not eurosceptical and at the outset went far beyond being europhobic and it must be remembered that this British leader has always been uniquely regarded as the quintessential example of Euroscepticism. Meanwhile, in the europhobic field, nuances between the most radical sectors, totally hostile to any European supranational decision making entity and the less radical sectors that can accept some form of intergovernmental economic cooperation, can be found ${ }^{14}$.

Sczerbiack and Taggart have directed the first major systematic study comparing eurosceptical phenomenon in various EU countries with notable empirical results and theoretical contributions of interest open to further discussion. These authors have chosen a dichotomous classification ("hard" and "soft" Euroscepticism) which - despite its inevitable reductionist schematic - has the advantage of being applicable for operational purposes. This is a manageable dual definition that though having received some criticism and is open to modification, has borne empirical fruit. What these authors call hard Euroscepticism implies opposition to the EU, with key principles and/or policy: parties and sectors that fall into this category or demand their countries leave the EU or their policy proposals are so contradictory and antagonistic with the Community that there is no chance of their fitting in. From this perspective (in fact, Europhobia), the EU must be rejected, either because it violates national sovereignty and would serve to obscure "globalisationist" interests (radical right) or it is used as a tool of "big capital" to impose neoliberalism (radical left). Consequently, the EU is perceived as an anti-national matrix, techno-bureaucratic, elitist, undemocratic and unpopular: empirical research has shown that this type of scepticism is much less common than the other. Meanwhile, soft Euroscepticism implies that it does not object to the principle of integration itself, but only certain Community policies, that, in the opinion of the groups that occupy this space, are harmful to the "national interest". The soft Eurosceptics can accept the benefits of mutually beneficial cooperation between States, but reject the transformation of this into a European supranational political authority. Therefore, soft Euroscepticism implies an instrumental view of the EU and a limited view on the extent of integration, hence the opposition to the EU is not direct or of principle, but partial and sectorial ${ }^{15}$.

14 Kopecky, Mudde, 2002, p. 300-302. Sczerbiak and Taggart, whose simplified scheme has been academically successful. It does, however, have the rare intellectual honesty to recognise that Kopecky and Mudde's looks a lot better than theirs, op. cit., 2008, II b, p. 247.

15 Sczerbiak, Taggart, 2008, I a, p. 8 and 11-12 (in these two pages the table of countries and parties with their eurosceptical variants are included); Tiersky, 2001, p. 3-4; Lubbers, Scheepers, 2005, p. 227 and 232. 
This dual classification has some problems especially in the case of those parties who have substantial ambiguities of both the principle and of the community policies. In this sense, the generic category of Euroscepticism is excessively wide in ranging from parties and groups who reject the membership of their countries to the EU to others who strongly oppose only some of its policies. This soft classification runs the risk of being so vague that almost any disagreement with EU policies could fit in it - the concept then needs to be fully refined. There are also complicated cases such as those parties who are against the principle of integration, but do not advocate leaving the EU. This, in principle, seems illogical, however, it is relatively common in certain CEE countries where there are anti-EU parties that do not advertise the fact because their countries need EU funds and they are not aware that no alternative exists. Another example of a difficult fit are those parties who distrust the current process of integration, not for going too far, but for precisely the opposite (the "Eurocritics" of the radical left who refuse to be labelled as eurosceptical $)^{16}$.

Sczerbiak and Taggart recognise that it is not easy to unequivocally define the concept of Euroscepticism given the notable differences in context of each case and so admit the inherent difficulties when it comes to coining a general pattern applicable in all countries. At the same time, they assume that from an empirical stance the distinction hard/soft is not always easy and so, for example, both authors admit they have included in the soft category parties that are essentially pro-integrationist, which forces us to clarify the scope of the term. Indeed, although a party may have some serious reservations about some EU policies, it should not be classified as eurosceptical for this reason alone, as the key is to verify if it is in favour of the principle of integration. If a party is in favour of this and in general, of the direction the community is taking, although it may disagree with a specific policy - even one of importance - (these specialists mentioned none other than the CFSP) it can not be defined as eurosceptical. The pertinent question that arises is: where can the line be drawn on what sovereignty a party is willing to cede to determine whether or not it is eurosceptical? The answer is not easy as the question is not so much quantitative (a party may object only to many "secondary" EU policies), but qualitative (a party may object only to few "fundamental" EU policies). Of course, this raises a new question: regarding community policy - what is a secondary and what is fundamental? To determine which EU policies are "peripheral" and what others are "core" is something arbitrary and subjective. It is true there may be some very clear, specific examples: if a party opposes the EMU

16 Sczerbiak, Taggart, 2008, I a, p. 8; Kopecky, Mudde, 2002, p. 300. 
as a block it is eurosceptical (or, where appropriate, eurocritical), but not if it only opposes the CSF, for example. Taggart and Sczerbiak admit that it is debatable to determine which policies are or are not central and in this sense they have sustained the CFSP policy is not central: for current practical purposes it is true (because of its low real density and in part for its strict intergovernmental character), but to oppose its limited deployment is a deeply anti-integrationist policy and therefore it seems clear that objectively it is not a secondary question ${ }^{17}$.

Both authors admit that their binary categories are not necessarily exclusive and that some parties may have elements of both, since their programme policies on European integration are not always made abundantly clear, making their classification difficult. More particularly, Sczerbiak and Taggart recognise the problem of conceptualising parties that not only do not oppose integration, but also criticise existing processes as inadequate (radical left) as eurosceptical. This ideological group of parties - in the main pro-integrationist in principle - is often severe in judging the existing process, which - in practice - tends to produce retardant objective effects on the construction of Europe which so far has advanced with the slow and contradictory functionalist method. In this case, it poses a problem of form and substance: in theory they are very integrationist parties but, in fact, they are not, since they do not facilitate the small concrete steps of the "central block" at all, always disqualifying the same as "insufficient". In any case, from a conceptual point of view, it seems right to distinguish this type of opposition of the majority on the radical right because in criticising the current state of integration as being insufficient and, above all, the direction that governments are taking, it should not be automatically categorised with the block of Eurorejectors (what is relevant in this regard is to consider most radical left-wing parties as eurocritical). Still, Sczerbiak and Taggart were right to point out that the more types there are, the more difficult it is to operationalise and to categorise them in parties. With this, the scale hard/soft should be interpreted as a continuum, not as two stagnant compartments ${ }^{18}$.

\section{Causes of Euroscepticism}

There are many different factors driving the rise of the phenomenon (economic, political, cultural) and these manifest themselves with variable intensity depending on countries and formations. The expansion of European integration in primarily political and not only in economic

\footnotetext{
Sczerbiak, Taggart, 2008, I b, p. 361 and II b, p. 249-250.

18 Sczerbiak, Taggart, 2008, II b, p. 246 and 252; Rovny, 2004, p. 45.
} 
areas has generated more and more resistance in significant sectors of national public opinion. In as much as the latter has been broadly accepted, the former much less so, which, incidentally, has contradicted the strategic expectations of neofunctionnalists. So, Euroscepticism - as a reactive phenomenon - indicates a negative perception of the increase in community integration, the EU institutions and the assessment of its performance. In the approaches to the study of the causes of Euroscepticism, the utilitarian perspective has focused on calculating cost/profit (increasingly unbalanced in favour of the former, which would generate many losers), the political theories of "democratic deficit" of the EU (suspicion of supposedly incomprehensible and distant Community institutions) and the cultural issue in the area of identity (weak feelings towards Europe versus strong of national roots). In short, what is rejected or on what issues are there reservations?: 1) the loss of national sovereignty, 2) the indefinite expansion of the EU, 3) the expansion of responsibilities, 4) the imbalance of power between the EU and States in favour of the latter in certain areas, 5) the imbalance between the Community institutions themselves generating opacity and 6) specific community policies. In addition, the open and unfinished character of the EU (a possible final format has never been outlined) and its permanent process of readaptation contributes to favour the rise of Euroscepticism $^{19}$.

This phenomenon is a consequence of the perceptions of some elites and citizen groups on their primary preferences: if public opinion is not satisfied with domestic policies and believe that further European integration may change this, they will be pro-European and, inversely, consider that when Community policies are less desirable than or are more harmful than national policies, they will be eurosceptical. Thus, opposition to European integration is more an explicit rejection of and/or concerns about the EU's ability to effectively ensure tangible benefits, on the feasibility of a genuine European democratic governance and the risks to national identity. There are then fears for the future of the welfare state (increasingly challenged at all levels), the loss of popular control and democratic quality (the Eurosceptics believe that from the point of view of regulatory legitimacy the EU is much poorer than nation states) and for a supposed project forcing homogenising integration, impossible by definition in a Europe as heterogeneous as the mosaic of peoples that it is. Euroscepticism reflects hostility toward global governance in all its dimensions, something viewed negatively in

19 Eichenberg, Dalton, 2007, p. 132-133; Hooghe, Marks, 2007, p. 119; Dubé, MagniBerton, 2009, 2009, p. 77; Siegers, 2009, p. 116. 
the civic perception of the lack of accountability of EU institutions and the delegative nature of these $\mathrm{e}^{20}$.

The removal of economic barriers in the EU has altered the balance between capital and labour in domestic markets and increased competetion for jobs. In particular, less skilled workers tend to feel prejudiced and consequently, their support for the EU is low. In addition, in some cases, institutional and decisional complexities of the EU contribute to increased distrust and suspicion regarding the limited effectiveness of Community authorities. Add to this the uncertainties caused by the Euro and rising renationalistic trends in various European governments, both of which have contributed to the development of Euroscepticism ${ }^{21}$.

In studies of European integration there was initially an overwhelming predominance of views focusing on elites and only since the 1990s has in-depth research on public opinion been developed. This means that, on one hand, we must distinguish between Euroscepticism in parties and citizens, and on the other, the wide range of possible attitudes (by area), both of which reflect the multidimensional nature of support or not for European integration ${ }^{22}$. Hix has thoroughly systematized the complex relationships between parties, interest groups and voters formulating the following theses: 1) voters and parties of the radical left and right tend to be more eurosceptical than voters and parties of the "central block", 2) individuals and groups who support the government parties tend to be less eurosceptical, 3) when the "domestic" policy is to the left or right of the European average, voters of left or right wing parties tend to be eurosceptical, 4) voters and parties in majority democratic systems tend to be more eurosceptical than in systems of consensual democracy, with some exceptions, 5) left wing electors and parties were more eurosceptical in the 1970s, 1980s and 2000-2010 and right wing electors and parties in the 1990s, 6) voters, parties and interest groups of the large States tend to be more eurosceptical than those of small states, however, there are exceptions ${ }^{23}$.

20 Carey, 2002, p. 388; Hooghe, Marks, 2007, p. 122; Siegers, 2009, p. 115-118; Leconte, 2010, p. 247 and 256.

21 Gabel, 1998b, p. 940; Wessels, 2007, p. 295 and 296 and following on; Leconte, 2010, p. 24, 30, 35 and 39; Lubbers, Scheepers, 2010, p. 791.

22 Eichenberg, Dalton, 2007, p. 142; Krouwel, Abts, 2007, p. 256 and 261 (includes a scale to operationlise degrees); Wessels, 2007, p. 304; Hooghe, Marks, 2008, p. 6.

23 Hix, 2007, p. 136-140 


\section{Social Euroscepticism}

It is a debated question to clarify whether the EU strengthens or weakens civil society and in this sense, civic images and perceptions of the meaning attributed to "Europe" are relevant to the study of social Euroscepticism. With regard to interest groups, the distancing of the churches, union unrest, criticism of the majority of the "new social movements" and even fundamentalist sectors (in a neoliberal sense) of the business confederations against "excessive" EU regulatory zeal is perceptible (for different reasons in each case). The mass media deserve a special mention as they have had much to do with the phenomenon of Euroscepticism, since in some cases (the UK especially) they have set the European agenda of the national "political class" and have contributed massively to exacerbate hostility towards the EU. Naturally, the media landscape is plural, but the eurosceptical media is powerful and influential in several countries. However, neither the opposite case can not be ignored: in some countries the majority of the media has ended up backing the EU and this, paradoxically, has resulted in emphasising Euroscepticism in some cases (Scandinavian countries). There is one type of media (fundamentally British) that seems to have "specialised" in Euroscepticism (the sensationalist tabloids), although not necessarily has all of this always been eurosceptical. In this area, the absence of a true European "public sphere" and the absolute predominance of national frameworks is noted ${ }^{24}$.

When analysing the dimensions of Euroscepticism it is essential to set out from the classic distinction of eastonian origin between diffuse generic support and what is specific to the system, in this case, the European. In general, research has found a notable lack of diffuse support (typical of states) for the EU and a higher incidence of specific support according to areas, sectors and circumstances. With this, the distinction between the two separate types of support has been, in turn, criticised for being "fuzzy" - given that civic assessments of the EU and European integration are more complex and dynamic than those of this binary mode ${ }^{25}$. Additionally, it is useful to clarify what is supported or rejected and - in this sense - it is useful to consider the triple meaning of the policy that the English language captures more subtlety: polity (structures), politics (processes) and policy (results); that is, the EU institutions, European politicians and public policy in the EU. This set includes assessments of politician's responsibility, institutional

\footnotetext{
24

Leconte, 2010, p. 191, 203-204 and 211-212; Kufer, 2009, p. 37.

25 Gabel, 1998a, p. 27; Sánchez-Cuenca, 2000, p. 147-171; Krouwel, Abts, 2007, p. 255; Leconte, 2010, p. 250.
} 
accountability and the legitimacy resulting from the system, dimensions on which various gradations are given.

Eurosceptical sectors of public opinion believe that the EU is normatively invasive, does not function democratically and distorts the principle of subsidiarity through the continuous expansion of Community competence. In addition, many citizens do not agree with the fact that the EU ceaselessly accumulates powers and this is what provides a potential basis for eurosceptical parties. While generally acknowledging that some policies do require supranational cooperation (environment, the fight against organised crime), in others it categorically rejects any community "intrusion" (education, culture, including health policies). Nearly half of Europeans are eurosceptical regarding cultural policies, more than half on the issue of immigration and asylum and third on foreign policy ${ }^{26}$.

The membership of a State to the EU has different consequences for its citizens (winners/losers) and this makes their interests align or conflict with this. Statistical analyses provide significant evidence of the variation of support/rejection to integration in terms of different dimensions ${ }^{27}$.

Table 2: Types and Dimensions of Support/Rejection of the EU

\begin{tabular}{|l|l|}
\hline \multicolumn{1}{|c|}{ Types } & \multicolumn{1}{c|}{ Dimensions } \\
\hline $\begin{array}{l}\text { Support / } \\
\text { reject on principle }\end{array}$ & $\begin{array}{l}\text { Economy: high regulation v low regulation policy: } \\
\text { supranational integration v intergovernmentalism }\end{array}$ \\
\hline $\begin{array}{l}\text { Support / } \\
\text { general rejection }\end{array}$ & $\begin{array}{l}\text { Support/opposition to the EU as a whole support/rejection } \\
\text { of the EU as a "regime" }\end{array}$ \\
\hline $\begin{array}{l}\text { Support / } \\
\text { reasoned rejection }\end{array}$ & $\begin{array}{l}\text { Effectiveness Legitimacy instrumental rules expressive } \\
\text { Identity }\end{array}$ \\
\hline
\end{tabular}

Source: Fuchs, Magni-Berton, Roger, 2009, p. 23. Personal adaptation.

Indeed, there are three major analytical criteria to gauge the overall phenomenon of Euroscepticism: 1) effective evaluation (in instrumental/ utilitarian terms), 2) cognitive assessment (from the rational/normative standpoint) and 3) emotional evaluation (in terms of identity). The first has a clear economic dimension and focuses on the cost/profit correlation, the second proceeds from a judgement of political legitimacy on the problems of European governance in relation to the national government, the third is linked to the intensity of the feelings of national/

26 Lubbers, Scheepers, 2005, p. 226 and 238; Krouwel, Abts, 2007, p. 258; Wessels, 2007, p. 292.

27 Gabel, 1998a, p. 71; Gabel, 1998b, p. 937; Wessels, 2007, p. 300-301 (cf. table with percentages). 
european belonging and loyalty ${ }^{28}$. From the outset, utilitarian approaches focused on the market predominate, following this there was a focus on directly political implications and finally, studies in identity developed remarkably. In fact, there is no single explanatory factor, although the intensity of one or other according to country, social sectors and the moment may vary and this is because the popular support/rejection of European integration is not fixed but variable and multifaceted ${ }^{29}$. The empirical analyses confirms the differences in support for European integration according to levels of vocational training (less educated, less support), something only relativised by the factor of identity that is interclassist. Beyond the material interest of the participatory effectiveness, in the long-term, identification with Europe would be the key driver for strengthening the process of European integration ${ }^{30}$.

Since diffuse support for the EU is weak and the enthusiasm for the same is low, what is essential continues to be the utilitarian criterion. In this sense, the key indicator for assessing the cost/benefit is the net fiscal transfers to the EU budget: whenever a country contributes more than it receives, it is paving the way - in principle - for Euroscepticism. Developed European states with a good system of social protection are those in which the phenomenon manifests itself more clearly. This has started to become increasingly visible since the Euro was launched as the economic convergence policy has provoked increasing social costs that negatively affect a large sector of public opinion in those countries, increasing demands for policies of renationalisation. These social concerns for the costs of progress in European integration would seem to indicate that most Eurosceptics would be the losers of the same. As a consequence, if the acceptance of the EU rests mainly on the material benefits expected and on proper and effective management, but the two separate elements fail, then rejection and reservations toward the same grow so exponentially that the heterogeneous group of malcontents can then lean toward clearly eurosceptical parties to "punish" pro-EU politicians. Moreover, neoliberal policies in expansion since the 1990s make the EU less attractive to broad sectors of society, who witness the cutting of welfare state benefits ${ }^{31}$. In summary, the economic interests of citizens

2828 Gabel, 1998a, p. 9-10, 11-12 and 20; Van der Eijk, Franklin, 2004, p. 32-50; Hix, 2007, p. 133; Hooghe, Marks, 2007, p. 124; Krouwel, Abts, 2007, p. 253; De Vries, Edwards, 2009, p. 7; Leconte, 2010, p. 251; Lubbers, Scheepers, 2010, p. 810 (p. 793 includes references to several Eurobarometers).

30 Gabel, 1998a, p. 114; Gabel, 1998b, p. 949 and 951; Wessels, 2007, p. 298-299.

31 Lewis, 2002, pp 166-168; Sitter, 2002, p. 12; Lubbers, Scheepers, 2005, p. 224; Manners, 2006, p. 77; Sczerbiak, Taggart, 2008, II a, p. 22 and 24; Siegers, 2009, p. 117 and 120-121; Leconte, 2010, p. 47-48, 173, 175 and 177. 
and their impact on their attitude towards the EU has been analysed under both microeconomic and macroeconomic criteria, i.e., both from the constant liberalisation of markets and from the personal evaluation of performance of the national economy in the context of the EU.

The cognitive evaluation links not only determined values of political legitimacy (participation, accountability) but also the judgement of the pros and cons of the relationship between national governments and EU authorities, as well as their respective performance. Empirical studies have shown that the direct effects of cognitive appraisal are not as high as expected and that, therefore, this dimension only relatively determines positive or negative attitudes towards the EU. From this latter point of view, Eurosceptics who focus on values reject the "interventions" (real or perceived) of the EU that have to do with their system of beliefs regarding social order (on matters such as divorce, abortion, minority rights, the balance between freedom and security and others). Many citizens believe the EU is being "invasive" in these areas and thus, for example, the expansion of Community competence in areas such as immigration or criminal law is not always accepted ${ }^{32}$.

The factor of identity initially received little attention in studies of Euroscepticism, but when it became evident that the ethnoterritorial dimension was very relevant to significant sectors of the public, it gained considerable attention in research on the matter. There are now numerous studies that apply the Moreno question to the (self) identification of citizens: the compatibility European/national is sometimes accepted, but not always and invariably to a greater or lesser extent. In principle, exacerbated nationalism is a clear obstacle to the process of European integration and in this sense, many citizens reject the notion of "European citizenship" or European symbols, so that this feeling has ended up having a strongly negative impact on the evaluation of the EU. Although the compatibility among identities is manifest (albeit unbalanced, given the generally derived and complementary character attributed to European identity), many citizens reject this. All things considered, a strong national identity is not necessarily incompatible with support for European integration, even for instrumental reasons ${ }^{33}$. In any case, polls show a weak sense of European identity, or even of European citizenship, given that Europeans are heavily linked to their national identities, a really significant factor in explaining the reservations towards the EU. For some citizens "Europe" is a pipe dream and its people have nothing in common, although others do recognise the

\footnotetext{
Mößner, 2009, p. 172; Leconte, 2010, p. 57 and 59.

33 Carey, 2002, p. 407; Fuchs, Guinaudeau, Schubert, 2009, p. 91 and 96; Leconte, 2010, p. 50-52, 54, 90, 97 and 110-111; Lubbers, Scheepers, 2010, p. 787.
} 
existence of common cultural ties and shared values; without which a single political identity could not be mechanically deduced. Given the strong predominance of national identity and non-existent practice of an effective European identity, it is understandable that the EU is perceived by some as a threat to their own community. In addition, there are citizens of European states that are deeply suspicious of citizens from other member States and in this sense, Euroscepticism is presented as a manifestation of nationalist withdrawal ${ }^{34}$. On the one hand, the nationstate (or, where appropriate, sub-national community) is the primary framework of belonging and loyalty for the great majority of citizens and on the other, EU enlargement to the CEEC in 2004 or the candidacy of Turkey have increased civil unrest regarding national identity and a clear retreat from the multicultural society, a trend that could only be reversed if emotional Europeanism is developed ${ }^{35}$.

\section{Political parties and Euroscepticism}

Ordinarily, attitudes pro or anti-EU are often highly connected with the political system itself: as citizens are poorly informed about European politics, it is common for their views on the EU to be strongly influenced by national politics. In principle, the countries benefitting from EU funds tend to be less eurosceptical than net contributors. When a country is admitted also has some influence: in Spain the unanimity of the "political class" and the receipt of funds were important keys for the consolidation of democracy (which explains the high civic Europeanism), while in the CEECs tough internal economic reconversion and neoliberal direction which the community took did not help to make the EU popular. In any case, the traditional argument that the founding members would be so associated with the EC that they would not be largely eurosceptical almost by definition, has been greatly downplayed after the referendums in France and Holland in 2005. This means that the phenomenon of opposition to the EU is not reserved for traditionally reticent States, but is also found in countries that have always been supporters of the integration process. From all this, real different national realities exist: 1) States with limited response in which the principle of integration is not rejected and criticisms focus on the peripheries of the party system, 2) States with an open response in which criticism does not affect only small extreme radical parties, but

\footnotetext{
34 Carey, 2002, p. 388, 390 and 392; Leconte, 2010, p. 61-62. 65, 180,181, 184 and 186.

35 Gabel, 1998a, p. 122; Carey, 2002, p. 397 and 403; Mc Laren, 2004, p. 899-901; Hooghe, 2007, p. 7; Hooghe, Marks, 2007, p. 123; Wessels, 2007, p. 304; Hanley, 2008, p. 197; Leconte, 2010, p. 182-183.
} 
also important ruling parties in government and 3) States with constrained response where there are serious reservations about the process, but accepting its inevitability (the case of the CEEC) ${ }^{36}$.

The eurosceptical phenomenon manifests itself with more force and clarity in the developed nations: in the strongly redistributive States (e.g., Sweden), less wealthy citizens are likely to quickly adopt Euroscepticism and in States with a lower redistributive level (e.g. the UK) the richest citizens may also lean toward this position. The former group fear the cutting of social benefits and the latter do not want to be permanent net contributors to EU. A different analysis must be undertaken with the CEECs: with these countries after 1989, the idea of the "return to Europe" was strongly imposed and for that reason virtually no significant political movement to oppose integration into the EU emerged, as both elites and society knew there was no alternative. However, the serious difficulties during their transitions (especially economic) and disappointment at a social level after admission to the EU (obviously quick, positive, large scale effects are not possible) have favoured the emergence and development of eurosceptical political movements. In the CEE there is a predominance of widespread acceptance of the principle of integration, hence the dominant Euroscepticism there is clearly soft as reservations and criticisms are constrained by the objective need to be "eurorrealist". In other words, perhaps the EU has not given everything expected of it, but almost everyone knows that the CEECs have no choice and that explains their pragmatic acceptance of it. It is not always easy to distinguish in the CEE who really opposes the principle (formally very few parties) and who opposes the trajectories (in this case there are several examples), while it seems an increasing degree of Euroscepticism is evident in some of the newly independent States (the Baltic countries) than in those States with a long history, with the occasional hybrid case. The truth is that the continuing process of Europeanisation of political parties in the CEE and their integration into transnational federations will increasingly assimilate those of Western Europe: given this, there are highly integrationist parties and others much less $\mathrm{so}^{37}$.

Institutional structures also have their influence on the acceptance/ rejection of the EU (decentralisation, proportional representation, multiparty formations): the States that meet the above characteristics seem to

\footnotetext{
36 Krouwel, Abts, 2007, p. 264; Sczerbiak, Taggart, 2008, Ib, p. 349; Leconte, 2010, p. 69-70. 73 and 76; Lubbers, Scheepers, 2010, p. 790-791.

37 Kopecky, Mudde, 2002, p. 298; Taggart, Sczerbiak, 2004, p. 3 and 8; Neumayer, 2008, p. 136; Sczerbiak, Taggart, 2008, II a, p. 15-16 and 18, II b, p. 246; Ladrech, 2010, p. 140-143.
} 
have adapted better to the EU, although the empirical evidence is less. The type of welfare state can also tilt public opinion in favour or against the EU as well as the functioning and performance of political institutions themselves (the quality of national democracy) and that - in theory - the worse the quality of national democracy, the greater the support for European integration, something not always verified. The newly independent States are more reluctant to formally cede national sovereignty (the Baltics, for example), but states with a very long historical tradition can be quite contrary to the supranational community (the United Kingdom, Scandinavia). In turn, institutional, regulatory and decisional constraints of the EU can cause contrary reactions in some countries and tensions with certain governments ${ }^{38}$.

National and European election processes show elements of confrontation variables in European issues and in this sense, the role of political parties can be very decisive. Firstly, there is less Euroscepticism in each national arena if the parties overwhelmingly favour integration (not without exceptions), although these do not always adequately assess the balance between the pros and cons of moving forward with this. In this context, the issue of extending the $\mathrm{EU}$ or not is of little use in determining whether a party is eurosceptical or not because, although the British conservatives are very supportive of indefinite extensions to block any federalist scenario, the French postgaullistas - always very nationalistic - prefer to deepen integration sooner rather than later ${ }^{39}$. Fort he rest, the absence of a genuine European party system favours the rise of eurosceptical tendencies.

In the construction of Europe it is evident that genuinely federalist parties are very few and very weak and that the key lies in the majority "central block" parties. In this area there has been a change in perception as the center-right, which had been the main driver of the European Community, has considerably weakened its historical supranational projects, while the center-left, which had serious initial reservations, has now become the main champion of the current process. Bearing this in mind, it can not be ignored that the issue of integration has been very divisive internally in some parties and that in some ideological groups conflictive issues have emerged: for conservatives the degree of acceptable supranationality, for the Christian Democrats the question of formalising "Christian roots" (this is something that, in general, divides Catholics and Protestants, the former being more confessional, the latter more secular), for liberals the tolerable level of regulation or for

\footnotetext{
38 Leconte, 2010, p. 79-80, 82-83, 86, 137 and 143.

39 Gable, 1998a, p. 115; Fuchs, Magni-Berton, Roger, 2009, p. 18; Lubbers, Scheepers, 2010, p. 811-812.
} 
socialdemocrats the minimum non-negotiable reach of social protection. This means with all of them there are perceived swings of opinion: the Christian Democrats - who had been "Euroenthusiasts" - have slowed their earlier impulses for political integration, the Liberals, who had zealously defended the common market now oppose the increase of its regulations, the Social Democrats - who criticised the original EEC for its social insensitivity - now see that the only hope of preserving the welfare state lies with the EU, regional nationalists - initially opposed to a union of states - believe that the EU offers them a chance to try to realise the autodeterminist principle ${ }^{40}$.

The success of European integration during the 1960s and 1970s strengthened the pro-integrationist vision of the political elites of the "central block", the reservations of the more radical right and left wing formations being marginal at that time. However, since the 1990s, tensions and the strength of parties critical of the EU have increased. In this regard, the eurosceptical phenomenon is far more typical of the parties of structural opposition (in terms of Panebianco): since European integration is managed by governments, it is almost "natural" that critics are parties in permanent opposition, something which - in some cases has emerged as an useful electoral strategy once the time of lenient social consensus towards EU institutions finished.

In principle, the more distant the likelihood of being the ruling party, the easier it is to appeal to Euroscepticism as a distinctive element of protest against governing political elites ${ }^{41}$. This does not preclude eurosceptical parties from the possibility of accessing government, however, in this case, they moderate their criticism from this position and postpone some of their less compatible objectives with the UE ${ }^{42}$. In practice there are indeed elements that mitigate many eurosceptical options as parties are, in fact, office-seeking rather than goal-seeking, hence the search for positions of responsibility prevail in these cases. In fact, some traditionally eurosceptical parties thoroughly deradicalise their previous anti-EU bias when acceding to government (the greens, for example) and neither is the impact of their integration into transnational party federations negligible, the same that tend to reproduce reservations and/or opposition to European integration.

40 Hooghe, Marks, 2008, p. 19; Fuchs, Magni-Berton, Roger, 2009, p. 19; Leconte, 2010, p. 101-102, 114-115, 121, 124 and 125-126.

41 Taggart, 1998, p. 382; Sitter, 2002, p. 5, 11, 14 and 24; Harmsen, Spiering, 2004, p. 32 .

42 Taggart, 1998, p. 383; Tierski, 2001, p. 5; Sitter, 2002, p. 12 and 20; Taggart, Sczerbiak, 2004, p. 21; Leconte, 2010, p. 15-16. 


\section{Ideology and strategy of the radical parties}

Generically the radical parties of the right and left wing are the most likely to take a eurosceptical stance, but grouping them all together in an undifferentiated way can lead to misinterpretation, so it is therefore useful to distinguish three positions: parties that advocate leaving the $\mathrm{EU}$, parties that advocate cutting its powers and parties that plan to expand the same. The first group are explicitly anti-integrationist, the second group do not reject the principle of integration, but consider that the current EU is forcing the integration of some incompatible elements (for these groups the EU is too inclusive), the third group does not reject the principle (the opposite is the case), but believe that the EU is moving too slowly (for them it is too exclusive). To be more precise: the opposition to any kind of integration (negative rejection) are actually Europhobes, whilst being against the current EU does not necessarily imply being anti-integrationist as there are parties that aspire to a different type of integration (positive rejection). The latter should be classified as eurocritical as they repudiate the current process as insufficient: they are anti-integrationist, but do not believe the EU will move more clearly and decisively in a supranational direction.

When analysing the positions of the renowned eurosceptical parties, we must distinguish between those who support a minimum of intergovernmental economic cooperation (the most) and those who even reject such a possibility (the least). In any case, various eurosceptical parties believe that the EU has gone too far, advocating in turn the renationalisation of some ceded policies and others (few) proposing an exit. Opposition to the current process of European integration focuses mainly on two dimensions: cultural-identity and socio-economic, without forgetting a third related to the "democratic deficit" of the EU. The radical right especially criticises the European Union for threatening national sovereignty and ethnic identity and the radical left for neoliberal policies only benefitting big business. Additionally, community institutional opacity and the non-participatory and delegative character is establishing uncontrollable supranational political power ${ }^{43}$.

In any case, the electoral support for radical parties is limited, as is their parliamentary representation. If support for these parties increases, it would suggest that popular support for integration is decreasing, and yet the results of the analyses show that the growth of opposition to the

Tierski, 2001, p. 1-2; Lewis, 2002, p. 151-153 and 157; Taggart, Sczerbiak, 2004, p. 5; Hanley, 2008, p. 192; Hooghe, Marks, 2008, p. 21; Sczerbiak, Taggart, 2008, IIa, p. 2-3 and II b, p. 255; De Vries, Edwards, 2009, p. 8-9; Lubbers, Scheepers, 2010, p. 791. 
establishment has more complex effects. For example, the rise of the radical parties can cause the growth of support for integration from citizens who do not support them. Therefore, it should be clear that radical opposition parties represent electoral minorities and can paradoxically contribute to building support for integration among those who do not vote for them ${ }^{44}$. Better put: it is known that the radical right is generally more eurosceptical than the radical left as ethnic ultranationalism is more difficult to integrate than socio-economic demands. Just as the radical right is not only opposed to the current direction of the EU, but has serious reservations about the principle of integration, the radical left does not usually pose the latter question but focuses on the methods the community uses ${ }^{45}$.

EP elections tend to favour eurosceptical parties because they are perceived as "second class" in which there appears to be nothing really important at stake. These are election-consultations operating in a mode of "second round" or "primaries" in many countries, usually offering a classic opportunity to "punish" the government of the day and are non operative as a strategic vote (which favours small, new and radical parties). Even if you add together the Eurosceptics of the central parties and the percentage increases to about one third, the strength of radical groups is much lower and also their degree of cohesion in the EP is weak. The members of the EP tagged with the label of Euroscepticism fall under four ideal types: 1) anti-EU (rejecting both the project and EU policies), 2) minimalist (can accept the project, but disagree with the majority of its policies), 3) reformist (offering moderate criticism both of the project and its policies) and 4) resigned (rejecting the project in theory, but accepting policies in the main) ${ }^{46}$.

\footnotetext{
44 Gabel, 1998a, p. 87; Leconte, 2010, p. 15.

45 Manners, 2006, p. 79-81; Benedetto, Quaglia, 2007, p. 482-487; Lubbers, Scheepers, 2007, p. 71-92; Hanley, 2008, p. 148, 179 and 186; Lubbers, Scheepers, 2010, p. 790.

46 Overall Eurosceptics in the EU average 32\%, with internal scales (14\% inflexible, $9 \%$ critics, $9 \%$ indifferent), with significant contrasts by country: $46 \%$ in the United Kingdom (29\% irreducible), but only $10 \%$ in Luxembourg (only $2 \%$ unyielding): Wessels, 2007, p. 300. Holmes, 2002, p. 1; Sczerbiak, Taggart, 2008, II, p. 19; Leconte, 2010, p. 128-131.
} 
Figure 1

Moderate

Resigned

$$
\begin{gathered}
\text { Radical rejection } \\
\text { of European } \\
\text { integration }
\end{gathered}
$$

criticism of actual EU

\begin{tabular}{cc} 
Resigned & $\begin{array}{c}\text { Radical rejection } \\
\text { of European } \\
\text { integration }\end{array}$ \\
Reformist & $\begin{array}{c}\text { Anti-EU } \\
\text { Radical rejection } \\
\text { of actual EU } \\
\text { Minimalist }\end{array}$ \\
& $\begin{array}{c}\text { Moderate } \\
\text { criticism of } \\
\text { European } \\
\text { integration }\end{array}$ \\
\hline
\end{tabular}

Source: Costa, Brack, 2009, p. 257.

In general, the success of eurosceptical parties has much to do with national conditions of political competition and although European integration per se does not restructure the party system, its influence is perceptible ("Europeanisation") in the same. In this way, Euroscepticism contributes to increased electoral volatility and in its case, to further fragmentation of the party system ${ }^{47}$. In the competition between left and right the use of Euroscepticism may sometimes work electorally when European issues are divisive (at the heart of elites and public opinion) being then of political benefit. Euroscepticism, then, is a reactive symptom of certain types of parties and a usable element according to their ideology and actions. However, there are very few monothematically eurosceptical parties, that is, who turn this orientation into the exclusive and defining base of their policy. There is another factor that helps explain why some parties turn to Euroscepticism: the growing weakness of the classical forms of political representation. As traditional parties are unable to offer new forms of really refreshing organisation and proposals, opposition to the EU can function as an opportunity for some to criticise the conventional mechanisms of participation ${ }^{48}$.

The different degrees of hard and soft in ideology and strategy allow the classification of various party groups into four generic Eurosceptic categories, parties motivated: 1) by hard ideologies (ultra-nationalists, orthodox communists), 2) by hard strategies (populist), 3) by soft ideologies (agricultural, postcommunist) and 4) by soft strategies (conservative). Combining the two dimensions can create another typology: 1) single-issue parties whose raison d'être is direct opposition

\footnotetext{
47 Harmsen, 2005, p. 285; Fuchs, Magni-Berton, Roger, 2009, p. 13; Leconte, 2010, p. 117 and 120. 
to the EU (UKIP, the list of Philippe de Villiers in France), 2) populist protest parties using Euroscepticism as one more element of their ideology and strategy against the establishment (DF, LN, the old list of Pim Fortuyn in Holland), a movement radicalising the most extreme parties (FNVB) in their closed defence of national sovereignty and even some classic Communist Parties (KKE, PCP, KSČM), 3) central government parties that are somewhat critical of some community policies (the left wing of the French Socialist Party or Swedish Social Democracy) or - more broadly - most of them (the British Tories are archetypal in this respect and some CEE right wing parties such as the Czech ODS and the Polish PiS have joined them ${ }^{49}$.

Beyond the classic right/left division (basically socio-economic) other conceptualisations of identity and attitudinal elements have developed. In this way, Hooghe and Marks classify parties in relation to the eurosceptical phenomenon into two broad categories: 1) green / alternative / libertarian (gal) and 2) traditionalism / authority / nationalism (tan). "Gal" type parties are more integrationist than type "tan", but this dichotomy is very sketchy because sometimes "gal" / "tan" trends coexist in one party. There are "tan" parties that, for economic reasons, could be considered more integrationist (the French Gaullists) and others, type "tan" that are much more reticent (the Nordic Green Left) due to their opposition to neo-liberalism. In the CEEC a link is often given between left and "tan" and right and "gal", the contrary to what happens in Western Europe ${ }^{50}$.

A singular specific mention must be made on the subject of nationalist parties at a sub-state level (ethnoregionalists in international academic terminology) given that the European integration process provokes contradictory reactions in them. To begin with, most of them are favourable - in principle - to European integration with two sets of considerations: 1) against more Europe, less state, in which they are included and 2) only in the EU does it seem feasible to try to articulate more or less sovereigntist joint projects given that within these small States are viable. In territories where the issue of identity is politically mobilising, this type of party often opts for an instrumental Europeanism of a classical nature as it aims to reproduce the intergovernmental model of the nation state on a smaller scale. In some developed areas, regional political movements expressing reservations and even rejection of redistributive EU policies have emerged. A kind of increasingly

49 Taggart, 1998, p. 368-369 (includes a complete list of parties on pages 370-371, but this is now outdated); Sitter, 2002, p. 10; Rovny, 2004, p. 46; Harmsen, 2005, p. 281284 (provides a typology of five variants).

50

Hooghe, Marks, 2008 p. 16-19. 
unsupportive welfare chauvinism is being expressed within them, ranging from the radical right of the $\mathrm{VB}$ or the $\mathrm{LN}$ to more moderate conservative formations such as the Bavarian CSU. Therefore, in some rich regions there is the emergence of populist movements that reflect the "solidarity fatigue" of territories that, as such, do not receive EU structural funds because they are above the EU average and this may incline them towards a growing Euroscepticism ${ }^{51}$.

Party Euroscepticism has two facets, one ideological, the other strategic and that while in some the first is more influential and others the second, both elements are interrelated. In the first instance, parties of the "central block" are more pro-EU than radical parties, and in the second, the parties of government are much less eurosceptical (if they are, they have to moderate this when in power) than the permanent opposition. Over time, the centre right has become less integrationist, while the opposite has occurred with the center left, for their part, the opposition of the radical right and left tend to diverge in both the dimensions that they reject (supranationality and neoliberalism respectively) and the finalist perspective (less/more EU). In general, Euroscepticism is a conscious strategy of some parties that is also often linked to certain ideological conceptions and so the two dimensions do not exclude each other but have to be complementary ${ }^{52}$.

Although Euroscepticism is a cross-ideological phenomenon (neofascist, neo-populist, conservative, ethnoregionalist, confessional religious, agrarian, radical left) there is empirical evidence that there are doctrines that predispose to the same (the exclusive type of nationalist ideology) but others, however, much less (internationalist solidarity ideologies). For some analysts of the phenomenon, the ideological dimension is the most important factor to explain, above the strategic dynamics (Taggart, Kopecky and Mudde, Hooghe), while for others, although it provides a clue, it is not always is the most relevant (Rovny, Neumayer, Fuchs). From the latter the point of view is held that for practical purposes Euroscepticism is not an ideology in itself (except in very exceptional anti-EU single issue parties, such as the British UKIP), while contrastingly the strategic use of it is much more common. Ideologies are undoubtedly important, but are not sufficient for explaining the adoption of eurosceptical strategies in themselves: the right/left wing scale is insufficient to determine whether a party is

51 Haesly, 2001, p. 81; Karolewski, 2007, p. 23 and 31; Karolewski, Suszyki, 2007, p. 187 and 191; Hooghe, 2007, p. 9; Hoppe, 2007, p. 67.

52 Kopecky, Mudde, 2002, p. 319; Rovny, 2004, p. 34; Neumayer, 2008, p. 136 and 141; De Vries, Edwards, 2009, p. 11; Trenz, Wilde, 2009, p. 7; Leconte, 2010, p. $107-109$. 
eurosceptical or not as they exist in both spectra and this is what is required to combine the ideological and strategic explanation. In fact, the parties that use Euroscepticism as an element of political contestation and electoral competition are the result of a strategic choice determined by national conditions that encourage such mobilisation. From the start, it is more likely that hard eurosceptical parties will be so because of ideology and the soft parties because of strategy, although in the end - the most important factor is the distance or proximity to government: the farther from it, the more likely the use of this issue and therefore the phenomenon is recurrent in protest parties. In other words, the position in the national party system gives key clues and as a consequence, it seems that the practically permanent opposition parties may be more prone to Euroscepticism ${ }^{53}$.

Taggart, 1998, p. 376-378; Sitter, 2002, p. 23 and 24; Rovny, 2004, p. 34 and 36-37; Krouwel, Abts, 2007, p. 263; Sczerbiak, Taggart, 2008, I a, p. 9-11, II b, p. 255 and 257; Fuchs, Magni-Berton, Roger, 2009, p. 9 and 14; Roger, 2009, p. 276. 



\section{CHAPTER II}

\section{Background of Parties and their Impact on the 2009 Elections}

\section{Traditional positions of the parties}

\subsection{Are the radical right and left comparable?}

As has been noted by various analysts, from the TEU of 1992 positions challenging the process of European integration have continually increased, which has ended the previous situation of permissive tacit consensus held by citizens. This worked without any significant problems between 1957 and the SEA in 1987, the text which marked the beginning of separation. On the one hand, there appears an increasing Europeanisation of protests against the current EU, and on the other, a radicalisation towards the ends of the political spectrum on this issue. Although deeper motivations of the radical right and left are not the same, the fact is that in both persuasions, the rejection of the community establishment is politically and electorally profitable. In any case, the highest level of challenge comes from the radical right - who are benefiting most today from the impasse of the EU, although the radical left have, in turn, an average effect not as insignificant as is often assumed in comparison to it. The appearance of substantial political forces contrary to the "Community method" reflects the crystallisation of a new cleavage in the European political scene ${ }^{1}$. In the sixth Legislature of the EP (2004-2009), these were the percentages of rejection of the current process of European integration in the eurogroups that included the largest number of opponents: 1) Independence and Democracy (radical right), $92.3 \%$ of its MEPs, and 2) GUE/NGL, 79.1\%; if - in addition - the Union for Europe of the Nations is considered (conservative right), in this Eurogroup, the percentage was $47.7 \%{ }^{2}$.

Poirer, 2007, p. 42 and 53; Heine, 2009, p. 164; Van Eijk, Franklin, 1996; Lacroix, Coman, 2007; Balme, Chabanet, 2008; Neumayer, Roger, Zalewski, 2008; Mc Donnell, Newell, 2011, p. 443.

2 Brack, 2009, p. 187. The UEN should be included more in the field of the conservative right rather than in the radical right (notwithstanding certain reactionary 
A proper distinction is not always made between the rejection of the current process of European integration and the negation of any form of supranational linkage. Consequently, it is not academically relevant to amalgamate any criticism of the EU, however radical it may be, with the opposition to the very idea of European integration. It is therefore essential to distinguish the different types of opposition to the EU as the most radical is opposed to the very principle of integration itself, while another may just challenge the existing operating and institutional framework. This means there is one type of "antisystem" opposition to the EU (rejecting all it represents in substance and form) and another that essentially refers to its policies. The first is a global opposition, of principles, which fully affects the project of European integration; the second - in contrast - affects its functional dimension. Structural opposition is very small in the EU (even among the radical right), while the functional opposition large in these political areas ${ }^{3}$. Indeed, direct rejection of the EU is defended only by a minority of radical parties that represent an irresponsible opposition in sartorian terms. By contrast, the critical judgment of the institutions and policies is the norm with the majority of the radical right and almost all of the radical left. In any case, criticism of aspects of European integration has a negative variant, typical of populist eurosceptical parties (the vast majority of the radical right) and a positive one, common in progressive groups (not without some exceptions in this field). In the latter case, the radical left tends to focus their criticism on the current ongoing process and on its leading actors, not on the idea of integration per se. While anti-European impulses are more common with the radical right (for their usual ethnic nationalism), with the radical left they are much less frequent (because of their theoretical doctrinal internationalism), criticising this EU and asserting that they want "another" Europe 4 .

The process of European construction affects the traditional bases of the nation state and this favours the exacerbation of narcissistic nationalism in significant sectors of public opinion, which, in part, are captured by radical organisations. On the one hand, the absence of a governing majority and an opposition in the European Parliament merely reinforces those who challenge the EU, and on the other, the complexity

impulses of some of its members) for its composition and programmes. The UEN has been partially replaced in the seventh Legislature (since 2009) by European Conservatives and Reformists that group, among others, the British Tories (formerly "observers" in the PPE/DE) and the Polish and Czech conservatives of the PiS and ODS respectively.

3 Mair, 2007, p. 3-4, 10 and 12; Brack, 2009, p. 185; Heine, 2009, p. 9-10.

4 Crespy, Petithomme, 2009, p. 26 (Introduction) and p. 336 (Conclusions); Heine, 2009, p. 11 and 149. 
of the distribution of competences (to know "who does what") and the usual institutional opacity of the Community have increased feelings of uncertainty and questions about the future. In addition, the technocratic language of the community elites and tough economic targets that subordinate social rights favour radical parties. The construction of the EU counts minimally on citizens, is top-down and elitist, working through barely transparent or controllable consociative agreements.

In this way, the radical parties of the right and left gather part of the social discontent generated by some negative consequences of the current process of European integration and are able to mobilise - for different reasons - part of the anti-EU civic sentiment ${ }^{5}$. Euroscepticism (and, often, Europhobia) is one of the reasons for the electoral success of the radical right who present globalisation and Europeanisation as two sides of same denationalising coin. The radical left also rallies concerns about the uncertainties of the current process and particularly as economic integration (from the EU Treaty of Maastricht) and police cooperation (Schengen) advance, the hostility of this political spectre increases against the Community establishment. In both cases, the fact of not being parties in government (with some very few exceptions), the tendency to accentuate criticism of the EU is greater ${ }^{6}$.

In addition to these reasons, other factors also contribute to explain the greater or lesser degrees of rejection/criticism of the EU in various EU countries. The degree of public support for European integration is, for example, relevant: in France this has ranged between 50\% and 70\% depending on the period in question (which leaves ample room for potential challenge), whereas in Italy and Spain it has fluctuated between $60 \%-80 \%$ in the first case and $70 \%-80 \%$ in the second (with much less room for manoeuvre for the anti-EU opposition) ${ }^{7}$. The institutional system and the national party system also affect this dimension and do or do not accentuate opposition to the EU: for example, if the electoral system encourages partnerships, it is more likely to attenuate eurosceptical impulses. Finally, strong, long term partisan bureaucratic leadership explains the persistence of more or less favourable attitudes to integration (the radical right have contrasted the anti-Europeanism of Le Pen and the possibilism of Haider, in the radical left the Euroscepticism of Cunhal and strong support for integration of Carrillo).

Brack, 2009, p. 182; De Vries, Edwards, 2009, p. 6.

6 Cosseron, 2007, p. 136; Frölich-Steffen, Rensmann, 2007, p. 124; Heine, 2009, p. 161-162.

7 Benedetto, Quaglia, 2007, p. 487-488. 
The interrelationship between the radical right and the left in the European system of parties is a complex issue because although a strong ideological antagonism exists (with occasional agreement in certain cases), to some extent all compete for a relatively similar popular electorate $^{8}$. So in theory there is no relationship as they are at odds ("particularism" of the right versus "universalism" of the left), but both reject the "system" (from different perspectives) and dispute similar electoral margins (the discontent, the losers). Indeed, it is still striking the not insignificant space where an objective coincidence is produced: anti-system, anti-globalisation, anti-US, against the "powerful", for national sovereignty (with degrees, differences and nuances), in favour of those marginalised by the community establishment and all with a vision - at times - politicist (politics in "command", politics must decide everything) ${ }^{9}$.

However, notable differences are also evident: 1) those on the right are nativist and ethnocentric, xenophobic and obsessed with "security", favourable (with overtones according to parties) to the market economy, elitist and hierarchical (with an instrumental/functional concept of democracy) and conservative and conformist in the social order, 2) the left are internationalist/cosmopolitan (with conditions in some cases), favourable to open multicultural societies, advocates of strong public intervention in the market (for the sake of solid Welfare States), supportive of base democracy, being equitable and showing solidarity in the social order. Perhaps one of the most contradictory elements (for the radical left) is that of national sovereignty: their rejection of any ethnic concept of the same being evident, there are many example of parties of this type strongly advocating "national interests" against Brussels. In this case, such a policy is defended with the argument that the EU is an agent of capitalist globalisation, harmful to people in general and workers in particular and also with political workings of poor democratic quality. Although the radical left believes in principle that the nationstate is an anachronism destined to disappear in the process of global

\footnotetext{
Backes, Moreau, 2008 (Conclusions), p. 601; Brack, 2009, p. 189; Hooghe, Marks, Wilson, 2002, p. 965-989.

9 Chirumbolo, Mayer, De Witte, 2006, p. 255-258 and 266-267. An interesting recent study emphasises the nationalism of the radical right and left as the main axis of challenge to the EU from both spectra. Although the authors recognise the differences between the exclusive ethnic nationalism of the first and the civic linked to popular classes of the second, they affirm that it is the principal common element that explains Euroscepticism in both ideological groups of parties. Although true that the Orthodox CPs are now in effect, nationalist, it is much less evident in the case of several postcommunist parties and the New Left: Halikiopoulou, Nanou, Vasilopoulou, 2012, p. 1-2, 5 and 29.
} 
transformation, its conception of European politics remains essentially national. In rejecting the EU, the radical left objectively coincided with the extreme europhobic right, fanatical defender of the Nation-State ${ }^{10}$.

Even in the economic area differences are not always as great because significant sectors of the radical right criticise neoliberalism for harming "ordinary people". In this sense, the two spectra are benefiting from the erosion of social democracy and from the serious decline of its traditional hegemony with the classic working class ${ }^{11}$. Some authors have coined the expression gaucho-lepenisme (left wing "LePenism") to highlight the populist use of denunciation of the "powerful" in the ambit of the working class. Indeed, radical right and left compete - sometimes intensively - for an electorate affected by economic globalisation: the radical right benefits from the vote of the "chauvinists" of the Welfare State itself and the radical left from the discontent and protest of the losers. Therefore, the two spectra capture sectors of an electorate disenchanted with traditional establishment parties $^{12}$.

In short, the radical left is theoretically in favour of supranational integration, but rejects the economic values of the model existing in the EU, while the radical right rejects the whole idea of a Europe superior to nation-states. While the radical left focuses its criticism on the EU neoliberalism that is mining the Welfare State, the radical right emphasises national sovereignty and ethnic identity. The radical left benefits from popular fears of the loss and decline of social rights and the radical right exploits feelings of insecurity regarding extra-community immigration from abroad and the uncertainty and opacity of the decision taking mechanisms of Brussels. These strategies tend to favour a general process of withdrawal, mistrust and fear that "infects" the moderate centre right much more given that the radical left reject the issue of xenophobia outright. This does not mean that a sector of social democracy is partially sensitive to extremist pressures in these issues

10 In the French debate on the occasion of the referendum of 2005 , virtually all radical left formations were united in their rejection of the CTEU (the "nonists") in contrast to minority theses of well known advanced activists and intellectuals, such as CohnBendit or Negri, who favoured the text - aware of its limitations - as a first step to overcoming the anachronistic nation-state. Cosseron, 2007, p. 135 and 218; Crespy, 2008, p. 589-603.

11 Backes, Moreau, 2008 (Conclusions), p. 603; Van der Brug, Fennema, 2010, p. 61; De Vries, Edwards, 2009, p. 19-22.

12 Backes, Moreau, 2008 (Conclusions), p. 603-604. On the crisis of traditional social democracy: Lavelle, 2008, p. 7-45. The term gaucho-lepenisme left wing "left wing LePenism" is from P. Perrineau. 
(the traditional support of the Left in general for the model of a multicultural society has fallen) $)^{13}$.

\subsection{The arguments of the radical right}

The radical right's negative valuation of the EU is nearly unanimous, while there are varying degrees of rejection and even challenge (leave it, eliminate it, reduce it to just a forum for intergovernmental cooperation without supranational concessions). In any case, right wing party coincidence in opposition to every advance in integration is also complete, hence their systematic rejection of any treaty reform moving in that direction ${ }^{14}$.

The radical right is against the current EU supposedly because it would lead to a super-European federal state, but, - from this point on national positions are not always coincident. Some parties of this spectrum (fewer in number) propose to abandon or even eliminate it, but others suggest reforming it thoroughly to "slim it down" and remove powers that should then be renationalised. In this sense, most radical right-wing parties could support some form of loose economic cooperation between sovereign states that would create a large European free trade area. To choose any of the three strategies mentioned (opt out, liquidate, reformulate) depends on if, in defending the "national interest" it is more beneficial (at the end of the day, for each party) to choose one of these, on the understanding that all are against increasing the supranationality of the current EU, especially politically. In this way, some radical right-wing parties are more flexible than others in relation to the EU either because they need funds from the same and/or because their voters are not totally hostile to $\mathrm{it}^{15}$. Consequently, there are gradations from lesser to greater opposition, largely correlated to varying degrees of authoritarianism in every party this ideological family: 1) Europragmatics. The PRM, for example, was highly critical of the EU, but, - for instrumental reasons - it has softened its position because it expects material benefits (funds) from the same, 2) Eurosceptics. Not openly advocating leaving the EU or liquidating it, but rejecting almost

13 Brack, 2009, p. 188; De Vries, Edwards, 2009, p. 6 and 9; Van Spanje, 2010, p. 569 and 579. The effect of the thesis of the radical right in the moderate right: Raniolo, 2000, p. 261-266; Brustier, Huelin, 2011, p. 240-246.

Mudde, 2007, p. 159. On the general typologies of the radical right, beyond their specific positions on the EU, see: Various, 1998; Ignazi, 2000, p. 35-57 and id., 2003; Schain, Zolberg, Hossay, 2002; Betz 2002; Betz, 2004; Carter, 2005, p. 50 et seq. netjes, Edwards, 2005; Williams, 2006; Ivarsflaton, 2008, p. 3-23.

Mudde, 2007, p. 165-166 and 182; Hanley, 2008, p. 198-199; Vasilopoulou, 2009, p. 4. 
all policies regarded as "intrusive" (VB, LN), 3) Eurorejectors. For these the EU would be an intolerable and grave threat to national sovereignty and they would advise abandoning, even liquidating it (UKIP, BNP) ${ }^{16}$.

The radical right politically exploits some of the negative consequences of globalisation and European integration, hence their hostility towards the EU is connected with this its discourse and populist strategy (against the establishment, against the elites, against party politics, against immigrants and so on). The truth is that one of the main paradoxes of such parties is that their electoral successes force them to act within an institution - the EP - which they doctrinally reject ${ }^{17}$. For the radical right the EU is an instrument of leftist strategy to negate the values of the "silent majority" and, beyond that, "the idea of the EU is in many ways similar to the ideology of Communism" for their alleged "denationalisatory" and even "totalising" pretensions ${ }^{18}$. From this point of view, the radical right affirms that the EU would lead irreversibly to the European federal super-state, centralising, hyper-regulatory and a deadly threat to national sovereignty. Indeed, for these parties the EU has already established intrusive supranational body, with an intolerable expansive interventionalism which is mining nation states, national economies and cultures ${ }^{19}$.

The radical right, in its absolutism of the idea of nation, condemns Europeanisation as a process attacking the ethnic identities and sovereignty of peoples. Consequently, the EU contradicts the basic nature of each country in being an artificial device. The EU also favours the crystallisation of a multicultural society, which would mean the end of the native cultures of Europe. For a Hungarian radical rightist, the increasing integration of the EU would lead to "cosmopolitan homogenisation" and would convert European nations into simple provinces to serve the "powerful" 20 . In line with its traditional conspiratorial view of the world, for the radical right Europeanisation is nothing more than a further manifestation of globalisation led by the United States and international financial corporations, which is why the EU becomes an instrument at the service of supranational power elites. Consequently, the radical right rejects the Eurocrats in Brussels and all the "political

\footnotetext{
Mudde, 2007, p. 162-164; Vasilopoulou, 2009, p. 18.

Simón, 2007, p. 14; Brack, 2009, p. 179-180.

18 The quotation is from a radical right-wing Czech, in Mudde, 2007, p. 160; Poirer, 2007, p. 44-45.

19 Mudde, 2007, p. 159; Hanley, 2008, p. 192; Hanley, 2008b.

20 The affirmation is from Csurka, in Mudde, 2007, p. 193-194; Klandermans, Mayer (Conclusions), 2006, p. 271; Poirer, 2007, p. 57-58; Hanley, 2008, p. 197; Gibson, 2002; Vasilopoulou, 2009, p. 8.
} 
class" of the establishment. These parties reject the "Europe of merchants", one of whose alleged denationalising strategies is a permissiveness to non-EU immigration which is only in the selfish interests of "stateless bankers" 21 .

Although the radical right is in favour of market economy, it expresses this with close minded nationalist mentality and is therefore critical of the EU for affecting the competitiveness of national economies with its invasive and hyper-regulatory policies of supranational character. Consequently, the radical right criticises cross border EU neoliberalism and calls for, in all cases, a Welfare chauvinism against the same ${ }^{22}$.

In general, a large sector of the radical right advocates the renationalisation of the policies ceded to the community and the strengthening of "red lines" with more exclusions that impede the continued expansion of the competences of the EU. The list is extensive and covers all areas, not only supranational (which are rejected), but even many of an intergovernmental kind. What the radical right is clear about is its opposition to any federal scenario for the EU: "We reject any kind of European community state" ${ }^{\prime 2}$. The radical right only supports greater European intergovernmental cooperation in the face of the pressure from the United States and the "threat" $[\mathrm{sic}]$ from the Muslim world ${ }^{24}$. These parties have embodied (mostly) their principal objectives with respect to the "Vienna Declaration of parties and patriotic movements in Europe", 2005, which proclaim: 1) the acceptance, at the most, of a European confederation of sovereign and independent states, 2) the total rejection of the creation of a European super state, 3) the rejection of eventually incorporating countries from outside Europe (Turkey) into the EU, 4) cooperation against terrorism, Islamic fundamentalism and imperialism (of the United States), 5) the paralysis of migratory movements, 6) the support for policies encouraging increased birth rates and family development in the interests of ethnic homogeneity of European nations, 7) the rejection of globalisation and 8) justice for European ethnic communities ${ }^{25}$.

21 Le Pen's thesis, in Poirer, 2007, p. 57; Van der Brug, Fennema, Tillie, 2000, p. $77-$ 102; Klandermans, Mayer (Conclusions), 2006, p. 274; Mudde, 2007, p. 185.

22 Carchi, 2002, p. 272; Poirer (Conclusiones, en Delwit, Poirer), 2007, p. 311; Simón, 2007, p. 14; Mudde, 2007, p. 186.

23 The quote is from a German neo-nazi, Deckert (NPD), in Simón, 2007, p. 272; Mudde, 2007, p. 168; Hanley, 2008, p. 190.

24 Ibid., p. 171.

25 Ibid., p. 180-181. 
In short, the radical right rejects supranationalism and clings to an ethnic/territorial communitarianism, nativist and essentialist in character and this is what explains the firm defence of the nation state or, in the case of regionalist parties with this group ideology, of the community (in the case of VB or LN, for example). These parties offer malcontents and the losers from European integration a different identity (of an ethnically exclusive type) and those responsible for the main problems (the elites of the establishment and Brussels) ${ }^{26}$. Yet, despite his hypernationalism, the radical right supports a certain idea of Europe (neither pluralistic nor liberal, i.e. unenlightened) because it assumes the thesis, completely respectful to national sovereignty, of the "Europe of nations" (with certain Gaullists resonances). This formulation presents gradations according to national parties: 1) Europe of the nations, without going into detail (UKIP), 2) Ethnic European ("white" and "Christian") against multiculturalism and the continued influx of nonEU immigrants (VB, LN) and 3) imperial Europe (this is now a minority thesis, only defended by small, rather irrelevant extremist groups $)^{27}$.

After 1945 the radical right manifested a rejection of the dual hegemony that the United States and the USSR (who had colonised, divided and subordinated the continent that had been a former world power) had over the whole of Europe, albeit with a resounding nonsymmetric difference given its traditional anti-communism. The truth is that the radical right claims a certain "differentiation" of Europe in the world, hence its references to the mythical nature of this place as an ethnic community and as the mother of all civilized nations. There is, therefore, a certain myth about Europe existing with the contemporary radical right that has its origins in the classic fascisms that aspired to a "new European order." These parties admit a certain global cultural paneuropean reference linked to the idea of "Western Christian civilization", whose main practical effect is xenophobic and - today - especially Islamophobic. Indeed, the current emphasis of the radical right on "Christian roots" (all things considered, it is surprising that some parties in this ideological group have reservations about orthodox Christianity, such as the BNP) is explained by the net rejection of Islam. This has a double projection: internally - directed against Muslim immigrants residing in the EU (these would be "inintegratable" and potentially dangerous) and the externally - against the candidacy of Turkey. According to the radical right, this country should be totally excluded under any circumstances, not only for not being "European", but even

\footnotetext{
26 Poirer, 2007, p. 42; Rodríguez Jiménez, 2008, p. 343-344.

27 Tarchi, 2002, p. 273; Minkenberg, 2000, p. 170-188; Simón, 2007, p. 249-250; Liang, 2007.
} 
more accurately for being "anti-European" (historically the Ottoman Empire came about to oppose Europe and today there are radical islamist elements that could endanger the West). The least important is that these theories are weak or inconsistent because the key is to tune into the fears of a significant section of European voters ${ }^{28}$.

Given the structural ultranationalism of the radical right its significant difficulties for coordination at a European level can not be a surprise. Initially, the radical right had quite clear leadership from the FN and the MSI, but successive EU enlargements and the transformation of Italian neo-fascists into a non-extreme conservative party (AN) diluted such prominence. Despite several attempts to create a single parliamentary group in the EP this has never come about, hence the fragmentation of this sector. In the 2004-2009 Legislature one part of the radical right was in the Independence and Democracy Eurogroup and the other part not signed up. The ephemeral Eurogroup Identity, Tradition and Sovereignty created in 2007 barely lasted a year and, apart from that, the creation of this Eurogroup did not mean the incorporation of Independence and Democracy. In the Legislature inaugurated in 2009 the Eurogroup changed its name (with some changes in the participating parties) and it is the one that groups more parties of the radical right (the EFD) others being among those not signed up. In short, the radical right is against creating Europarties as have other European ideological groups because, in its opinion, it would only serve the thesis of pro-European Federalists. Therefore, only for instrumental and operational reasons various parties in this sector have agreed to converge in the $\mathrm{EFD}^{29}$.

\subsection{Specific parties of the radical right}

There are several EU countries with radical right parties whose election results exceed $10 \%$ of votes: France, Belgium, Italy, Denmark, Austria, Hungary, Romania and Bulgaria ${ }^{30}$.

First, within the Western European countries, Le Pen, the principal leader of the FN, said that the EU is "similar to the Soviet Union, cosmopolitan, detached from its Christian roots and swamped by Islam"31. The FN is therefore hostile to the European integration process because, in his opinion, it would have very negative consequences for France. The FN is opposed to any deal that limits national sovereignty,

28

29

30

31

Simón, 2007, p. 251, 255, 259 and 267; Mudde, 2007, p. 167 and 170-171.

Mudde, 2007, p. 172-179; Hanley, 2008, p. 179, 187 and 196.

Norris, 2009, p. 81. Although referring only to the EU-15, see the list of both right and left wing parties in de Vries, Edwards, 2009, p. 12; Kitschelt, McGann, 1995; Blaise, Moreau, 2004; Harrison, 2005a, p. 288; Hainsworth, 2008.

Mudde, 2007, p. 161. 
for example, the Schengen system. Subsequently, the French radical right has accepted the free movement of people, but only of Europeans in the strict sense to avoid loopholes for illegal immigration. Meanwhile, freedom of movement of capital represents an attack on national financial interests. In summary, for the FN Community institutions are not any more than an instrument in the service of secretive bureaucratic lobbies, hence in the face of such an artificial, anti-national and antipopular device, you should fight for another alternative, for the "Europe of homelands" ${ }^{32}$. At the end of the day, the FN is opposed to increasing European integration for cultural, political and economic reasons: among the first, for its rejection of immigration, its closed nationalism and xenophobia, among the second for its direct criticism that the Community institutions already weaken the nation-state, among the third, for its critique of worldwide neoliberalism (in its jargon) that limits national sovereignty ${ }^{33}$. For his part, Mégret (who split from the FN with very little electoral success) said the EU would aim to copy the United States, since its increasing integration would increasingly degenerate into a federal super-state, a policy which - basically - is nothing more than the strategy of the American empire, with which the EU would be its "Trojan horse" on the continent.

For the FPÖ, Europe is a community assigned to history, hence their reservations regarding Austria's integration into the EU. Additionally, for this party, the EU has an ungovernable negative supranational political vocation for the interests of the country itself - it also favours the model of a multi-cultural society that affects Austrian "spiritual values". The populist radicalisation of the FPÖ's discourse is what has led it to become increasingly critical of the current EU, although the party could accept a loose European confederation submitted to the principle of national subsidiarity, accepting that the common market, collective security and the defence of certain principles could justify its existence ${ }^{34}$.

Unlike the French radical right, its German namesake has not achieved national representation (among other factors, because of its fragmentation in - at least - three options), one of whose parties that evidently emerged in the 1990s (the Republikaner) defining the Maastricht Treaty as a "Versailles without arms", though it has never openly advocated leaving the $\mathrm{EU}^{35}$.

32 Fotia, 1995, p. 176-177; Simmons, 1996, p. 183; Hainsworth, Brian, Mitchell, 2004, p. 37-58; Sauger, 2005, p. 103-126; Vasiliopoulou, 2009, p. 9.

33 Neller, Thaidigsmann, 2009, p. 217-218; Evans, 2007, p. 133.

34 Leconte, 2005, p. 65, 68, 75, 77 and 79-80; Barnschier, 2005, p. 429; Virchov, 2007, p. $60-61$.

35 Mudde, 2007, p. 160. 
Finally, within the three principal EU states, the case of UKIP is different, since this party has neither had a neo-fascist past (in contrast to the FN or the German neo-Nazis), nor defended an ethnocentric programme (unlike the BNP). The UKIP is clearly a populist right party with a monothematic policy, reduced almost exclusively to the firm advocation of the withdrawal of the United Kingdom from the EU, with its fame for harming British national interests ${ }^{36}$.

In the case of some small European countries there clearly is - if anything - a strict defence of national sovereignty, which has a double projection: against further transfers of powers to the EU and against immigration proceeding from outside the EU. Consequently, parties like the DF, the PVV or LAOS declare themselves openly anti-federalist although they may accept eventual mutually beneficial forms of intergovernmental economic cooperation - and advocate a drastic closure of borders against immigration.

Secondly, in the case regional parties, the radical right takes particular interest in the positions of the VB and the LN.

The Flemish radical right is against the solid and broadly pro-EU consensus of almost all the Belgian "political class" and so denounces the alleged "attacks" on national sovereignty, emanating also from a clear democratic deficit due to the "Eurocracy" of Brussels. The VB opposes the ongoing process of European integration since this - from its perspective - would lead to federalisation, fatal for "natural" national identity. The VB could accept - in its case - a loose economic confederation, mutually profitable, respectful of European ethnic identities. In any case, it entirely rejects the idea of giving the EU social, redistributive, educational or cultural powers. On the one hand, it should both limit itself to the role of the Commission and strengthen the Union Council (formerly Council of Ministers) and on the other, relaunch many community focused policies. All this accompanied by strict restrictions on successive expansions, reinforcement of protectionism, elimination of "European citizenship" and a return to national currencies. In contrast, the VB maintains a very significant exception to the rejection of supranational policies: security against the "threat" of Islam in general (which, of course, leads it to reject Turkey's presence in the EU) ${ }^{37}$. For this, the party maintains a certain ambivalent discourse regarding the EU: a strong desire for certain policies, but advocating the disappearance of others. So the VB is in favour of economic integration (with a dose of national protectionism, of course), of effective cooperation on defence

\footnotetext{
36 Norris, 2009, p. 294.

37 De Winter, 2005, p. 107; Vassilopoulos, 2009, p. 9.
} 
and security, strong common policies on migration, asylum and the fight against terrorism. However, it is radically opposed to the interference of the EU - not even indirectly - in educational and cultural affairs, social security or "law and order." In its view, a federal EU is not only totally unnecessary but is dangerous and harmful to its peoples, hence the VB's rejection of the notion of "European citizenship", which is deemed empty and even absurd. Finally, it should be noted that the party has relatively "Europeanised" its program in order to give - at least in theory - a possible route for the Flemish secessionist strategy ("independence in Europe"), a strategic adaptation of an instrumental character ${ }^{38}$.

The LN, increasingly critical of the EU, rejects a federalising scenario of the same and constantly calls for a limit to the expansion of its powers. Bossi believes that the EU is the "Soviet Union of Europe", sponsored by "communist freemasons and co-bankers" [sic] and that "Europe is the new fascism and we will carry out civil resistance against it" according to the usual demagogic rhetoric of the leaguist leader ${ }^{39}$. In the early 1990s this group seemed to opt for a tactical instrumental Europeanism of internal confrontation ("against more Europe, less Rome"), to abandon this view later. The LN does not advocate the exit of Italy from the EU, but rejects its expansion (especially the candidacy of Turkey) and its "interference" in local interests. The LN, apart from not encouraging the notion of "European citizenship" has continued to emphasise "Christian roots" - having accentuated its xenophobic strategy since the early twenty-first century. The LN accepts neoliberal economic integration as it is (although with the criteria of Welfare chauvinism), but refuses to extend this to more political areas. In summary, one can conditionally accept economic cooperation for the predicted material benefits, but reject almost any other link ${ }^{40}$.

Finally, a third specified block of parties is represented by those of the CEE area in which a constrained Euroscepticism manifests itself under the assumption that no alternatives exist to the presence of the same in the EU.

For the Hungarian radical right (JMM), the EU threatens the continuity of the Magyar ethnic group as an independent entity, given that - from this point of view - it would be the modern version of the USSR: "The European Constitution is a new Soviet system of centralisation which has been prepared in the west" and whose inspiration

38 Swingedow y otros, 2007, p. 85-86; Laible, 2008, p. 121 and 147-148.

39 The first quote is from Bossi in Mudde, 2007, p. 161, and the second from the newspaper La Libre Belgique, 5-3-02.

40 Rodríguez-Aguilera, 2009, p. 26-28; Vasiliopoulou, 2009, p. 10; Tarchi, 2007, p. 189 and 193-194. 
reminds us of the infamous breznevist theory of "limited sovereignty"41. Precisely in the case of the Hungarian radical right we should mention that there are certain neofascist features given that the JMM has recovered part of the ideological heritage of the national right wing of the interwar period and even the sinister "Arrowed Cross" from the final phase of World War II. This explains why its traditional anticommunism is ever recurring in the post-Soviet world even today. The Hungarian far right rejected Hungary's integration into the EU (the predecessor of JMM, the Truth and Life Party Itsvan Gurka) from the beginning, although it is not currently recommending its abandonment, it is in favour of the renegotiation of the terms of entry ${ }^{42}$.

With relatively similar though attenuated tones, the NSA has taken on more characteristics of the contemporary radical populist right and focused its criticism on the supposed denationalising "dangers" for Bulgaria resulting from its EU membership, in addition to rejecting "influences" of Brussels regarding the rights of the Turkish minority. The party exploits the sense of insecurity and desires for internal order and has been able to capitalise on diffuse social unrest against the $\mathrm{EU}^{43}$.

Meanwhile, the PRM captures, in part, the discontent of social margins affected by European integration and although as an ultranationalist party it is critical with respect to the transfer of sovereign powers to the EU, it has pragmatically attenuated its initial opposition to the same for financial benefits (funds) that the country receives. Doctrinally the PRM would prefer to be further from the EU, but it limits itself to criticism of some of its sectorial policies (for example, those related to the primary sector in Romania are still very relevant). This combination of nationalism, populism and pragmatism explains the PRM's peculiar kind of relative opposition and ambiguous Euroscepticism to the $\mathrm{EU}^{44}$.

\subsection{The arguments of the radical left}

Historically CPs were decidedly against the EC during the "Cold War" and "field" political ideologies. The EC was seen as an instrument of big capital and imperialism of the United States, and NATO the army of the Western block against the USSR. Therefore, the EC and NATO are two sides of the same coin reflecting capitalist transnationalisation.

\footnotetext{
41 Mudde, 2007, p. 160.

42 Beckett, 2007, p. 178-182.

43 Nedelcheva, 2009, p. 248.

44 Papadmitriou, Phinnemore, 2008, p. 73-75, 82-83 and 88-90; Gallagher, 2008, p. 301-302; Nedelcheva, 2009, p. 247.
} 
Since the Soviet invasion of Czechoslovakia in 1968 several Western European CPs not only distanced themselves from the model of real socialism, but became increasingly favourable of autonomous European integration, the case of Italian communism being the most obvious. However, still at the beginning of the seventies, Marchais (General Secretary of the PCF) went on to state that the EC was essentially a network of big business detrimental to national sovereignty and not even Gorbachev's perestroika in the mid-1980s helped change - in essence such a discourse. But the easing of international tensions had an impact on some CPs: Although the PCF (like the PCP or KKE) continued to cling to an orthodox position, the ICP would end up considering the EC and the PCE-PSUC in a positive light with their struggle to oppose the Franco dictatorship, viewing them favourably for the process of internal change. Therefore, the degrees of reservation to, rejection of or qualified support for European integration varied according to national parties and the historical moment ${ }^{45}$. The move of some Western CPs to gain independence from the USSR would highlight the phenomenon of "Eurocommunism" as an attempt (ultimately abortive) at a "third way" between the Soviet system and classical social democracy. The main "Eurocommunist" parties, with the PCB leading (which the PCE-PSUC and the interior part of the KKE immediately joined), saw in the EC not a manoeuvre of big business, but an opportunity for workers and the peoples of Europe. Since the early seventies the PCI had opted for the strategy of "historical commitment" which emphasised its acceptance of the EC and even NATO to try become a reliable partner in government. Over time, most of the PCs evolved from outright rejection of European integration to the acceptance of its inevitability. After the fall of the Berlin Wall in 1989 and the postcommunist restructuring of several of these parties there has been a clear shift in relation to European integration: for the majority, you should take not even a single step back, integration should be strengthened and above all, reverse the current dominant logic excessively favouring neoliberalism ${ }^{46}$.

Currently, almost all of the radical left (with varying degrees within this sector) is integrated into the Eurogroup GUE/NGL (and a number of the same parties in the PIE europarty) and can be classified into three categories for its ideological and programme postulates: 1) postcommunist and renovated CPs open to critically accept European integration (PRC, DL, IU), 2) "orthodox" CPs that are very reluctant and even hostile to the process (PCP, KKE, KSČM) and 3) renovated postcommunist eurorejectionist parties (Nordic green Left). This implies

45 Benedetto, Quaglia, 2007, p. 479, 482-483 and 485-486.

46

Ibid., p. 484-485, 490-491 and 496; Hanley, 2008, p. 143. 
the existence of two principal positions: 1) that of the parties that "critically" accept the EU and 2) that of those who have very serious reservations and even advocate the abandonment or dismantling of the EU, deeming efforts to change it useless. The vast majority of the GDP is favourable to keeping the EU, but reversing the current direction: they support the principle of integration, but demand the elimination of the neo-liberal model.

Instead, the "observer" parties of the PIE are mainly eurorejectionist, like those of the NGL, tinged with accentuated populism ${ }^{47}$. One explanation for the different European strategies for this group of parties is as much to do with their situation in each national political system as with their alliances and perspectives to influence the government. So parties that need to ally with social democracy and/or green parties should temper their rejection of the EU, while those who have few possibilities or expectations of access to government are often much more critical. This would seem to confirm Panebianco's thesis of the incidence of these factors on the characteristics and strategies of the parties (parties with a vocation for government/standing opposition parties).

One of the major alterglobalist groups, ATTAC (Association for Taxation of Financial Transactions for the Aid of Citizens ATFTAC) has popularised the main arguments against the EU in the radical left media: the principle of greater supranational integration is accepted, but the effective modalities of the current EU for this are totally rejected. So the ATFTAC does not accept the logic of the community establishment that discriminates between pro and anti-European according to whether or not their criteria and policies are shared. From this perspective, to criticise - even in depth - the current EU is not to be "anti-European" or "eurosceptical", it is to be against the hegemony of neoliberalism that sacrifices "social" Europe ${ }^{48}$.

The radical left has always had an ambivalent attitude towards European integration: while acknowledging its positive aspects (supranational values, eradication of war in the "old continent") it criticises some very negative aspects (the hegemony of capital, the "democratic deficit"). This ambivalence is apparent in the PIE, since it admits that the EU is a useful space for common political action, while rejecting its capitalist nature. The criticism of the current EU focuses on three dimensions: 1) the neoliberal drift, 2) the democratic deficit and

\footnotetext{
47 March, Mudde, 2005, p. 42-43; Harrison, 2005b, p. 293; Backes, Moreau, 2008, p. 577, 581, 584 and 592 (Conclusions); Hanley, 2008, p. 153-155; Heine, 2009, p. 158.

48 Crespy, Petithomme, 2009, p. 332 (Conclusions).
} 
3 ) the risk of mining national identities ${ }^{49}$. In general, the radical left believes that neoliberal Europe makes people compete with one another and emphasises nationalist limitations, which would require a deepening of democracy and an advance in social rights in counterbalance. Thus the radical left advocates an employment policy at a European level, a new political economic policy focused on enhancing public services and other development models. As a result of this, existing EU treaties should be repealed and a real "popular democratic process" should be opened to replace them ${ }^{50}$.

\subsection{Specific parties of the radical left}

There are several EU countries where radical left parties have a not insignificant presence in their various manifestations (predominantly postcommunist conversions and electoral coalitions, with the orthodox CPs being the fewer) ${ }^{51}$. Unlike the radical right, the radical left has been far more operative when coordinating supranationally: in 1994 the Eurogroup GUE was founded and was expanded the following year with the postcommunist Scandinavian (NGL). This offset the abandonment of the former communist Italians, formerly the largest contingent of the predecessor Eurogroup in the GUE, to become the PDS, which was then integrated into the PSE. In the GUE/NGL postcommunist parties mutually exist, platforms fuelled by Communists and some classic CPs and their reasonably smooth and continuous collaboration led to the majority founding the $\mathrm{PIE}^{52}$.

In 1991 the Forum of the New Left (on the initiative of IU) was created to exchange information and experiences and out of this came the idea of forming the PIE - which subsequently happened in 2004, driven by the DL and the PRC. In this Europarty two organic groups have come about: fully formed members and observers, quite critical of the former, but sharing a Eurogroup in the EP. In effect, the more radical parties (Scandinavia postcommunists and Orthodox CPs) reject the "moderation" and "reformism" of the PIE and consider that making excessive concessions to the EU system sometimes verges on Europhobia (KKE KSČM, PCP). This makes the PIE, as such, take an ambivalent position with regard to the EU: assuming it to be an

\footnotetext{
49 Dunphy, 2004; March, Mudde, 2005, p. 41-42; Cossieron, 2007, p. 136; Backes, Moreau, 2008, p. 576 (Conclusions); Van Hüllen, 2008, p. 464 and 471; Heine, 2009, p. 15.

50 Cossieron, 2007, p. 136-137.

51 March/Mudde, 2005, p. 24-25 and 27; Kitschelt, 1999; Hudson, 2000.

52 March/Mudde, 2005, p. 42; Hanley, 2008, p. 138, 144 and 148. Sobre GUE/NGL: Bell, 1998, p. 134-150.
} 
important space for common political action, but severely criticising its clear neoliberal leanings $\mathrm{s}^{53}$.

Although in general there are two main attitudes of the parties of the GUE/NGL to the EU (critical acceptance, deep reservations/rejection), it is preferable to distinguish three internal areas given the somewhat different ideological characteristics of each: 1) eurocritical postcommunist and renovated communists in favour of taking the greatest benefit from the EU possible and pressuring for the reversal of its present course, 2) Scandinavian postcommunists, whose ideological message is renewed, advocating the renationalisation of community policies and in some cases - an exit from the EU, and 3) orthodox communists, very doctrinaire and traditionalist, which - however - objectively coincide with those of the second block in their type of opposition to the EU.

Within the first block the PCF, DL, IU, the radical Dutch left and AKEL deserve specific consideration

Historically, the PCF has always maintained an orthodox (pro-Soviet) approach to the EC, presented as an instrument of large scale monopolistic capital and as a product of the "Cold War". The French Communists were staunch defenders of national sovereignty and opposed supranational policy, criteria that - indeed - were not at odds with a "tactical" and pragmatic acceptance of the community framework. On the one hand, the PCF consistently opposed all integrationist advances, deemed by definition as capitalist and imperialist manoeuvres, but on the other, it never advocated the exit of France from the EC, which should have been the logical corollary of its extremely negative assessment of the same. From the alternation of the left in 1981 the decline of the PCF was unstoppable, its policy towards the EU remaining the same: the rejection of the supranational policy and protesting against the capitalist character of community reforms. Having to ally with other leftist groups in order to survive (GFR), the PCF has modulated its direct and unsubtle criticism of the EU, while maintaining alternative proposals ${ }^{54}$.

PCF currently holds that the EU has focused on promoting and facilitating free trade and furthering the interests of big business over national and popular needs, being insufficiently democratic. Its criticisms are directed against neo-liberalism and community elitism affecting national sovereignty (the traditional nationalism of the PCF is long standing and has only dimmed in recent times), its alternative proposal

53 Hanley, 2008, p. 148 (list of members to 2007); Van Hüllen, 2008, p. 466-473 (list of members to 2007, p. 469); De Waele/Vieira, 2012, p. 63-67 and 80-81 (in these two last pages a list of members and and observers in 2009 are listed).

54

Dunphy, 2004, p. 91-103. 
being the "other" Europe with a "participatory" social economy respectful of "identities". The PCF aims to gradually combine French nationalism and Europeanism, with a Keynesian economy and representative democracy at the community level: a program deemed "reformist" by groups located to its left (the Trotskyists variants, in particular) who argue for a rigorous "quality" internationalism, socialism and base democracy with revolutionary tints (although with very few practical consequences). In any case, the radical French left as a whole decisively contributed to the failure of the CTEU in the 2005 referendum, especially as they managed to accentuate the internal divisions of the Socialists. It was precisely this opposing campaign that allowed the FCP to recover certain visibility in an increasingly declining phase of its influence and project their arguments criticising the social and democratic inadequacies of the CTEU ${ }^{55}$.

The DL, a party critical of the EU, assumes this to be irreversible today and therefore, it tries to promote core social policies to break the current dominant logic that is entirely favourable to "markets". This party is in favour of the principle of integration, but is opposed to the dominant neo-liberalism and the democratic deficit of EU institutions. To these two criticisms, the DL adds the submission of the EU to the United States because the CFSP/ESDP are part of NATO, an instrument to serve the strategic interests of the superpower ${ }^{56}$.

In the case of IU, it should be remembered that the SCP was clearly favourable to the EC as one of the fundamental elements of its strategy against Franco and that after the transition, it gave its full support for the integration of Spain into this body. A change in attitude was seen in the IU led by Anguita which derided the TEU or, later, the CTEU. Indeed, since then there has been intensified criticism of the neo-liberal policies of the EU and the direction taken by the CFSP/ESDP, being increasingly linked to the strategic interests of NATO. A minority of IU did not share this political reorientation and after a very intense and divisive internal debate, it left this collective (the group of the Democratic Party of the New Left) ${ }^{57}$.

The Dutch Socialist Party, which proceeds from the former extreme Maoist left and has today adopted more a moderate position, is

\footnotetext{
55 Milner, 2004, p. 59-81; Benedetto, Quaglia, 2007, p. 489; Cosseron, 2007, p. 57; Courtois, Andolfatto, 2008, p. 107; Heine, 2009, p. 55-56, 58, 60, 66, 70, 72, 75, 80$81,84,88,94-96,98-100,106,151-152,154$ and 156; Seidendorf, 2010, p. 429 and 431; Alexander, 2001.

56 Landwehrlen, 2010, p. 21; Landwehrlen, 2012, p. 142.

57 Hanley, 2008, p. 151; Benedetto, Quaglia, 2007, p. 492-493; Dunphy, 2004, p. 121130.
} 
nevertheless critical of the EU for its neo-liberalism and democratic deficit. So it campaigned successfully against the CTEU in the referendum of $2005^{58}$.

Also within this first block, it is interesting to note the change in position of AKEL with regard European integration: initially an outright rejection of the view that the EU was "an instrument of capitalism and imperialism" to a full acceptance of the same - from there its support for the accession of Cyprus to the EU, although it rejected the CTEU ${ }^{59}$.

Finally, mention should be made of a party that does not sit easily in this ideological sector, the SF, given its very singular characteristics. Despite its very severe criticisms of the EU, this group - in the end has ceased its direct antagonistic opposition of the same and no longer calls for the exit of the Republic of Ireland (or Northern Ireland integrated in the UK). In particular, the acceptance of the Stormont Agreement has contributed to relativise the traditional opposition to the $\mathrm{EU}$ of the $\mathrm{SF}^{60}$.

The second block is represented by the Scandinavian radical left extremely critical of the EU in countries where European integration is usually a very mobilising issue.

The VP defends the exit of Sweden from the EU, a thesis not advocated by the Danish radical left. In any case, both parties benefit electorally from widespread electoral social Euroscepticism, though this does not make them partners in government ${ }^{61}$. The VP opposed the entry of Sweden in the EC and has always voted against any further integration in ad hoc referendums (1994 and 2003) and is against the ECB and the Euro. The Swedish radical left argues that the EU would be detrimental to Sweden on issues such as employment, welfare, ecology and democracy, which a large part of public opinion is in tune with.

For its part, the Danish radical left, which initially took the same position (rejection of EU incorporation, the TEU, of the subsequent reforms of the same, or the EMU, almost always appealing for "No" in every referendum) has toned down its direct opposition to the EU recently. Today, the party accepts the EU as an unavoidable reality and understands that the EU can be a useful instrument of cooperation, provided that that there is a complete change in policies and that it does not intend to supplant nation states - as it is against an undesirable

\footnotetext{
58 Lucardie, Voerman, 2003, p. 172; Voerman, 2008, p. 30-31.

59 Steorgiu, 2008, p. 262-263; Charalambous, 2012, p. 258.

60 Hayward, 2009, p. 243.

61 Ersson, 2008, p. 158-162; Lucardie, Voerman, 2003, p. 218-221; Dunphy, 2004, p. 152; Hastings, 2012, p. 96-97.
} 
European federal super-state ${ }^{62}$. There is a perceptible double division on European affairs - internal and external - activists and voters exhibit contradictory posperceptiblerding this (ranging from Europhobia Europragmatism). The same phenomenon of initial outright rejection and pragmatic acceptance after the country's accession to the EU has also been seen with the Finnish radical left.

Finally, the block of orthodox communism is the most rooted in very traditional doctrinal positions, linked to the ideological heritage of the "Cold War".

To begin with, the PCP opposed the entry of Portugal in the EC in 1986, but then did not advocate its exit. This opposition was due to the fact that entry would threaten the "gains of the April revolution," which was yet another reason which prevented unified action with the Socialists. Only in 1988, the PCP accepted Portugal's presence in the EC as a "fact of reality", then trying to "benefit" from it. For the PCP for the bulk of EU policies would be harmful to Portugal: the CAP, the Stability Pact or employment, which is why this party opposes further steps of integration. In fact, the PCP has always rejected all reforms of EU Treaties precisely because they meant further deepening of the logic of integration. The official argument is that the gradual federalisation of the EU is no more than the other face of neoliberalism, mining inalienable national sovereignty and benefitting only large capital interests ${ }^{63}$.

The KKE has a strong tradition of nationalism and has always opposed to the entry of Greece into the EC. Among other factors because they would support Turkish interests against Greece. In its view, the EU would be as "imperialist" [sic] as the United States populism is one of the hallmarks of this party, the type of opposition effected by SYRIZA (which comes in part from the former KKE Interior) being different. For Greek Communists, the EU is a reactionary institution in the service of big business, anti-democratic and anti-national. Consequently, not only the KKE has opposed all reform of EU Treaties, but also considers that there is no possible remedy for the EU given its "class nature", advocating then the exit of Greece from the same ${ }^{64}$.

62 The SF voted "no" in the Maastricht referéndum (1992), Amsterdam (1998) and the UEM (2000): Ersson, 2008, p. 157.

63 Bosco, 2000, p. 66, 78-79 and 202; Dunphy, 2004, p. 115-120; Cunha, 2008, p. 197198 and 208; Jalali, Lisi, 2012, p. 205.

64 Kalyvas, Marantzidis, 2003, p. 16 and 22; Dunphy, 2004, p. 104-108; Marantzidis, 2008, p. 252 and 258; Backes, Moreau, 2008, p. 574 (Conclusions); Verney, 2011, p. $68-69$. 
Portuguese and Greek Communists must compete electorally in their countries with other more modernised radical groups of the left (the BE and SYRIZA respectively), which has led them to emphasise their criticism of the EU to differentiate themselves and capture the citizens unhappy with the policies of Brussels. Indeed, the BE and SYRIZA have succeeded is opening a path between classic social democratic parties and the classic "orthodox" CPs, - in European affairs, they hold rather critical positions, but favourable to supranationality (with conditions). This kind of "third option" between the center-left Social Democrats and the Communists obliges them to maintain a certain ambivalent European discourse: they reject the negative aspects of the EU (neoliberalism and "democratic deficit"), but it aim to overcome these from within the community.

Finally, it is interesting to note that although in almost all the CEECs the old CP rulers were converted into social democrats, some maintained their Orthodox identity: this is the case of the KSČM, which opposed the entry of the Czech Republic into the EU campaigning against on the occasion of the referendum. Once the country entered, the Czech Communists accepted this popular decision, but remain among the most critical of the EU and have always opposed any further integration (completely rejecting the CTEU) ${ }^{65}$.

\section{The elections to the European Parliament of 2009}

\subsection{Context and variables}

The elections held between 4 and 7 June 2009 were called after the failure of the CTEU (in the 2005 referendum in France and Holland) and before the adoption of the Lisbon Treaty (rejected by Ireland in its first 2008 referendum, then approved in a second with some opt-out clauses and finally ratified by all States in the autumn 2009). In these elections 375 million voters in the 27 states were called to choose the 736 MEPs for the VI Legislature, from 2009 to 2014. Contested by some 9,000 candidates, grouped in more than 300 political parties, and achieving

65 So anachronistically orthodox is Czech communism that it has refused to enter the PIE as a full member (it is an "observer"), not only for deeming it "reformist" and too close to the capitalist EU, but also by not taking the Statutes of this europarty which rejects Stalinism without hesitation: see Mares, 2008, p. 297 and 300; Hlovšek, Pšeja, 2001, p. 110-111; March, Mudde, 2005, p. 28-29; Hanley, 2008, p. 149; Ishiyama, 1998, p. 61-85; Nedelcheva, 2009, p. 241-246; Bozóki, Ishiyama, 2002; Grzymala-Busse, 2002; Perottino, 2012, p. 269. 
representation for 170 national parties represented (about six per state) to be subsequently integrated into seven parliamentary Eurogroups ${ }^{66}$.

Again, traditional elements of the European elections have been accentuated and confirmed: the character of "second class" (or even "third") of the same and the inability of the EP to communicate and, even more, convince. It emphasises the paradox that the steady increase in powers of the EP discourages citizens and at the same time, it is clear that parties carry out low-profile campaigns (of a domestic character) and the mass media pays little attention to such events. However, in this latter dimension a surge of media interest has been seen, but this has not helped to increase civic attention. Again, specifically European matters have occupied very little space (sometimes zero) in national campaigns and reiterated the widespread popular ignorance of European political protagonists $^{67}$.

The serious deterioration with the economic crisis revived the materialistic preoccupations of citizens, hence the traditional left/right axis superimposed supranationalism/intergovernmentalism. In the 2009 campaign the challenge to specific EU policies related to employment and immigration dominated for example and this fact benefited parties of the right that managed to tune in better than the left with fears and concerns of many voters. Indeed, the rightist parties used more "postmodern" campaign resources than the left and had more resources and better election professionals at their disposal, which contributed to their victory at the polls. Moreover, it is also true that national peculiarities and specificities of each party system and more particularly, of the respective election modalities had an impact both on the modulation of the campaign in each country, and the results segregated there ${ }^{68}$.

The previous legislature of the EP was marked by important debates about the nature of European integration (French and Dutch referendums in 2005 and Ireland in 2008), but the worse economic crisis since 2008

66 Upon entry into force of the Treaty of Lisbon on 1 December 2009 the number of MEPs increased from 736 to 754 . The figure of 170 national parties in the EP is from Bardi et al., 2010, p. 15-16. Trechsel reduces this to 168, id., 2011, p. 6. In contrast, Giebler and Wüst increase this to 216, id., 2011, p. 53; Caravita, 2009, p. vii; Coosemans, 2009a, p. 5; Gagatek, Trechsel, Breuer, 2010, p. XI. On the attention of the mass media: Jalai, Silva, 2011, p. 111-124.

Gagatek, Trechsel, Breuer, 210, p. XI; Schuck, 2011, p. 42-43 and 46; Hobot, Spoon, Tilly, 2009, p. 93-115; OSCE, 2009; Sigalas et al., 2010. On the classic thesis of "second class" European elections: Reif, Schmitt, 1980, p. 3-44; Bellucci, Garzia, Rubal, 2012, p. 26.

Dupoirer, 2009, p. 536; De Wilde, Trenz, Michailidov, 2010, p. 17; Giebler, Würst, 2011, p. 54 and 64. 
has meant that this is the primary concern citizens have. Consequently, the almost absolute predominance of economic and financial issues may not come as a surprise, followed by immigration and - to a lesser extent - environmental protection.

In any case, given the indisputable nature of the usual overwhelming dominance of national dynamics, the important problems of States (uncontrollable economic crisis, rising insecurity, environmental degradation) can not be overlooked and are at the same time European problems. The fact that groups especially critical of the current direction of the EU such as the radical parties of the right and left have obtained significant results highlights, on the one hand, how artificial it is to divide the national from the European and on the other, that the question of the nature and scope of European integration itself has political significance, at least in several countries ${ }^{69}$.

At the same time, an increasing debilitation of conventional politics is evident and this phenomenon is accentuated even within the institutions of the EU, far more anonymous than national institutions for citizens. This fact has greatly benefitted protest parties - especially some groups of the populist right - though the base rejection and/or criticism of the EU is a cross-political phenomenon. Even countries with tradetionally favourable public opinion showing majority support for European integration, saw growing disaffection in 2009 (Belgium, France, Germany), although others commonly labelled as eurosceptical the phenomenon has remained stable without developing more (Czech Republic, Sweden, United Kingdom) ${ }^{70}$.

Figure 1

\begin{tabular}{|l|c|c|c|}
\hline $\begin{array}{l}\text { Attitudes regarding the EU } \\
\text { in the elections of 2009 }\end{array}$ & Parties & Citizens & $\begin{array}{c}\text { Combined } \\
\text { average }\end{array}$ \\
\hline Currently Pro-UE & 35.1 & 19.1 & 25.9 \\
\hline Eurocritical (“altereuropean") & 11.0 & 9.6 & 10.0 \\
\hline Diverse Eurosceptical & 53.9 & 71.2 & 64.0 \\
\hline
\end{tabular}

Source: Percentages from De Wilde, Trenz, Michailidou, 2010, p. 13.

Personal adaptation.

If the establishment parties could contain the opposition to the EU, then this factor would have little weight in the political system, but when a certain threshold has been passed then it is not possible to

69 The 2008 Eurobarometer shows that $71 \%$ of European citizens expressed pessimism both about the eventual outcome of the economic crisis and the ineffectiveness of EU institutions: Coosemans, 2009a, p. 7; Ridola, 2009, p. 2; Schuck et al., 2011, p. 43, 47 and 50.

70 Costa/Brack, 2009, p. 255; Ridola, 2009, p. 3-5; Spanje, de Vreese, 2011, p. 423-425. 
marginalise it and it enters the agenda. It is true that overall the Eurosceptics obtained significant results in 2009, but not as large as predicted. The best results were achieved by the UKIP and the Martin list from Austria - progress was also made by the FPÖ DF, LN, LAOS, VB (very few), PRM, BNP, PVV and JMM, while the NSA and FN receded and the Polish LPR disappeared. Considering the rest, it was not without considerable interest to note the failure of the Libertas Project of the Irish millionaire Declan Ganley, a well known Eurosceptic, who tried to present common candidatures in the 27 community members: he only managed 12 and obtained a single member of the European Parliament (the Frenchman Philippe de Villiers). Libertas focused its campaign on the rejection of the Lisbon Treaty, but citizens turned their backs and when it came to protesting against the EU, they put their trust in traditional national parties critical of the $\mathrm{EU}^{71}$.

While abstention has varied according to the States, the significantly lower participation (the lowest since 1979) is undoubtedly one of the most striking points of the 2009 elections. Indeed, the trend of electoral disaffection has continued and so, on average, only $43.2 \%$ of citizens entitled to vote did so (in 2004 the number was $45.5 \%$ ), a phenomenon accentuated in most CEECs. The fact that participation seems to be in continuous decline has to do with the fact that the EP is not comparable to national parliaments and that despite its increased powers, it lacks legislative initiative, is not a genuine European government and, indeed, is a colegislating institution, not the exclusive Legislative organ ${ }^{72}$.

Figure 2

\begin{tabular}{|l|c|c|}
\hline Participation in elections to the EP & $\mathbf{2 0 0 9}$ & $\mathbf{2 0 0 4}$ \\
\hline Western Europe & 54.3 & $(-1.3)$ \\
\hline Eastern Europe & 32.2 & $(+1.4)$ \\
\hline
\end{tabular}

Source: Treschel, 2010, p. 5.

71 Gagatek, 2010b, p. 19; Coosemans, 2009a, p. 52; Coosemans, 2010, p. 99-100; Schuck et al., 2011, p. 50.

72 Table 2 should be qualified when national results are analysed since, for example, in the west there have been increases in participation in Denmark, Sweden, Austria and Luxembourg, with decreases in Italy, Spain and Greece. In the east there are increases in Latvia, Estonia, Poland and Slovenia, but decreases in Hungary and Lithuania. Germany $43.3(+0.3)$, Austria 45.9 (+3.5), Belgium $90.3(-0.4)$, Bulgaria 38.9 (+9.7), Czech Republic 28.2 (-0.1) 59.4 Cyprus (-11.79), Denmark $59.5(+11.6)$, Spain $44.9(-0.2)$, France $40.6(-2.1)$, Greece $52.6(-10.6)$, Hungary $36.3(-2.1)$, Italy $65.1(-8.0)$, Netherlands $36.7(-2.5)$, Portugal $36.7(-1.8)$ Romania $27.6(-1.8)$, UK $34.7(-4.1)$, Sweden $45.5(+7.7)$. The figure in brackets indicates electoral participation in 2004: Coosemans, 2009a, p. 8. Jones, 2011, p. 25. 
The second remarkable fact of the 2009 elections is the global victory of the right, from the radical (to a lesser extent), to the centerright (the principal winner): the PPE (which confirmed its character as a primary force) and the new parliamentary eurogrups of the CRE (which in part comes from the old UEN) and the EFD (ex ID) going from $36.7 \%$ in 2004 to $48 \%$ in 2009 and this does not include unregistered members of extreme right parties. Consequently, the European Parliament elected in 2009 is the most right leaning since the first direct elections in 1979, with the very negative results for the Socialdemocrats, discrete results from the radical left and slightly better results than in 2004 for the Greens. The economic crisis and the feeling of insecurity led to this conservative retraction and the strengthened protest vote capitalised by the radical right. It was precisely the pressure of ultranationalist and sovereigntist groups that dented the moderate right, tending to emphasise the reservations about any further progress in deepening European integration, hardening and restricting legal guarantees. Although the radical right are present in 21 of the 27 states, it did not reach $10 \%$ in 9 of them, but exceeded this figure in 12 . Its most significant support was concentrated in 7 states, in the west, The Netherlands (PVV, 17.0), Belgium (VB, 15.9), Denmark (DF, 15.3), Austria (FPÖ, 12.7) and Italy (LN, 10.2), and in the east, Hungary (JMM, 14.8) and Bulgaria (NSA, 12.0) ${ }^{73}$.

Table 1

\begin{tabular}{|c|c|}
\hline \multicolumn{2}{|c|}{ Sanction vote } \\
\hline Opposition wins & Government wins \\
\hline Bulgaria & France \\
\hline Cyprus & Italy \\
\hline Spain & Czech Republic \\
\hline Greece & \\
\hline Hungary & \\
\hline Portugal & \\
\hline United Kingdom & \\
\hline
\end{tabular}

Source: Frank, Isnard, 2009, p. 607-621.

The third interesting fact of the 2009 elections is the sanction vote, as it is known that the European elections intensified the extension of the same: in 2009 governing parties lost in 23 states (85\%), even more than in 2004. However, in the 11 States where the right and center-right parties were in power, these received the most votes in the election (the

73 Dupoirer, 2009, p. 540; Alexandre-Collier, Jardin, 2009, p. 583-590; Sterpa, Scoppola, 2009, p. 21; Coosemans, 2010, p. 98; Gagatek, Treschel, Breuer, 2010, p. XI; Deloy, Reynié, 2010, p. 479, 488 and 494; Treschel, 2010, p.6-7. Mc Elroy/Benoit, 2012, p. 152-153. 
only exceptions being those of Nea Demokratia Greek and Maltese National Party), while social democratic parties suffered a severe setback (with the exception of Slovakia). Indeed, the crisis of reformist left governments made the right wing a far more effective electoral option: social democracy was unable to present itself as a real European alternative and in the 8 European countries where they governed (alone or in coalition), the right won ${ }^{74}$.

\subsection{The radical parliamentary eurogroups}

To analyse the incidence of selected parties in this study, both the percentage of voting and representation reached in the EP should be taken into account - above all in terms of the ranking achieved in each country, as this last piece of information is one of the most significant when calibrating the political weight of each in its respective system.

Figure 3

\begin{tabular}{|c|c|c|c|c|c|c|}
\hline Country & Party & Votes & $\%$ & Seats & $\begin{array}{l}\text { National } \\
\text { Electoral } \\
\text { Ranking }\end{array}$ & $\begin{array}{c}\text { Parliamentary } \\
\text { Eurogroup }\end{array}$ \\
\hline Germany & DL & $1,969,239$ & 7.5 & 8 & 5 & GUE/NGL \\
\hline Austria & FPÖ & 364,207 & 12.7 & 2 & 4 & NI \\
\hline Belgium & VB & 647,170 & 15.9 & 2 & 3 & $\mathrm{NI}$ \\
\hline Bulgaria & NSA & 308,052 & 12.0 & 2 & 4 & NI \\
\hline $\begin{array}{l}\text { Czech } \\
\text { Republic }\end{array}$ & KSČM & 334,577 & 14.2 & 4 & 3 & GUE/NGL \\
\hline Cyprus & AKEL & 106,922 & 34.9 & 2 & 2 & GUE/NGL \\
\hline Denmark & DF & 357,942 & 15.3 & 2 & 4 & EFD \\
\hline Spain & IU/ICV & 583,708 & 3.8 & 2 & 4 & $\begin{array}{l}\text { GUE/NGL } \\
\text { V/ALE }\end{array}$ \\
\hline France & $\begin{array}{l}\text { FN } \\
\text { FG } \\
\end{array}$ & $\begin{array}{l}1,091,691 \\
1,115,021 \\
\end{array}$ & $\begin{array}{l}6.3 \\
6.5 \\
\end{array}$ & $\begin{array}{l}3 \\
5 \\
\end{array}$ & $\begin{array}{l}6 \\
5 \\
\end{array}$ & $\begin{array}{c}\text { NI } \\
\text { GUE/NGL }\end{array}$ \\
\hline Greece & $\begin{array}{c}\text { LAOS } \\
\text { KKE } \\
\text { SYRIZA }\end{array}$ & $\begin{array}{l}366,637 \\
428,282 \\
240,930 \\
\end{array}$ & $\begin{array}{l}7.2 \\
8.4 \\
4.7 \\
\end{array}$ & $\begin{array}{l}2 \\
2 \\
1 \\
\end{array}$ & $\begin{array}{l}4 \\
3 \\
5 \\
\end{array}$ & $\begin{array}{c}\text { EFD } \\
\text { GUE/NGL } \\
\text { GUE/NGL }\end{array}$ \\
\hline Holland & PVV & 772,746 & 17.0 & 4 & 2 & NI \\
\hline Hungary & JMM & 427,773 & 14.8 & 3 & 3 & $\mathrm{NI}$ \\
\hline Italy & LN & $3,126,922$ & 10.2 & 9 & 3 & EFD \\
\hline Portugal & $\begin{array}{c}\text { BE } \\
\text { CDU-PCP }\end{array}$ & $\begin{array}{l}382,011 \\
397,707\end{array}$ & $\begin{array}{l}11.5 \\
11.4\end{array}$ & $\begin{array}{l}3 \\
2 \\
\end{array}$ & $\begin{array}{l}3 \\
4\end{array}$ & $\begin{array}{l}\text { GUE/NGL } \\
\text { GUE/NGL }\end{array}$ \\
\hline \begin{tabular}{|l} 
United \\
Kingdom
\end{tabular} & $\begin{array}{c}\text { UKIP } \\
\text { SF }\end{array}$ & $\begin{array}{c}2,498,226 \\
126,184 \\
\end{array}$ & $\begin{array}{l}16.5 \\
26.0 \\
\end{array}$ & $\begin{array}{c}13 \\
1 \\
\end{array}$ & $\begin{array}{c}2 \\
1(\mathrm{NI}) \\
\end{array}$ & $\begin{array}{c}\text { EFD } \\
\text { GUE/NGL }\end{array}$ \\
\hline Romania & PRM & 419,094 & 8.7 & 3 & 5 & NI \\
\hline Sweden & VP & 179,182 & 5.7 & 1 & 6 & GUE/NGL \\
\hline
\end{tabular}

Source: Chiche, Boissieu, 2009, p. 737-776. With personal expansion and selection.

74 Coosemans, 2009a, p. 50-51; Coosemans, 2010, p. 98-99; Dupoirer, 2009, 2009, p. 537-538; Treschel, 2010, p. 11. 
As a result of this data the following descending scales of greater to lesser in both ideological groups of parties is obtained. With the radical right the downward progression is as follows: PVP, UKIP, VB, JMM, LN, DF, FPÖ, NSA, LAOS, PRM and FN. With the radical left: SF, AKEL, KSČM, BE, KKE, CDU-PCP, IU, DL, FG, SYRIZA and VP. Additionally, it is interesting to note the degree of generic Euroscepticism of national public opinions in the 2009 elections as a whole because sometimes, the results of parties situated in this spectrum exceed the percentage of the eurosceptical population, while on other occasions the opposite occurs.

Anyway, it is unnatural to mechanically extrapolate and in block the election results of radical parties and relate them directly to public opinion polls as the motivations of these and civic attitudes are always more nuanced.

Figure 4. Eurobarometer question:

"Generally speaking do you think your country being in the $\mathrm{EU}$ is a bad thing?" The percentages are reproduced from citizens who think so.

$\begin{array}{ll}\text { Germany: } 11 \% & \text { Denmark: } 13 \% \\ \text { Austria: } 19 \% & \text { Spain: } 9 \% \\ \text { Belgium: } 11 \% & \text { France: } 17 \% \\ \text { Bulgaria: } 7 \% & \text { Greece: } 15 \% \\ \text { Czech Republic: } 13 \% & \text { Holland: } 7 \% \\ \text { Cyprus: } 18 \% & \text { Hungary: } 23 \%\end{array}$

Italy: $16 \%$

Portugal: $16 \%$

United Kingdom: $32 \%$

Romania: $6 \%$

Sweden: $19 \%$

Source: Eurobarometer 71. June-July 2009

$<$ http://ec.europa.eu/public_opinion/archives/eb717eb713_annexes.pdf >, p. 38 .

In the previous legislature (2004-2009), the Eurosceptics of the radical right were basically in two parliamentary eurogroups, the UEN and ID, apart from several in the NI. The UEN had a very conservative ideological inspiration accepting intereuropean economic cooperation, but rejected supranational policy, while the ID - even more right leaning - included openly europhobic groups. In 2009 a new parliamentary Eurogroup, EFD was created, which - partly - follows the old thinking of the UEN and above all, the ID (its primary origin) and comprises 32 MEPs, just under the 37 the ID had in the previous parliament ${ }^{75}$. The strongest parties of the EFD are the UKIP, LN, DF and LAOS and this parliamentary eurogroup has accumulated a greater percentage of votes than the UEN and ID together (from $6.0 \%$ to $7.6 \%$ ), although not in numbers of MEPs. It is a rather heterogeneous parliamentary Eurogroup of various specific political dimensions, but united by a strong

75 Bardi et al., 2010, p. 57; Coosemans, 2010, p. 108; Mc Elroy/Benoit, 2012, p. 153154. 
Eurosceptical rhetoric. All members are staunch defenders of national sovereignty and are against the policy of supranationality, strongly criticising the Community institutions (for their "democratic deficit") and their policies (harmful to national interests) ${ }^{76}$.

The change in regulations of the EP in 2008 hampered the formation of parliamentary Eurogroups and this has once again harmed the classic extreme right-wing (25 MEPs are needed from at least 7 states). Indeed, this sector has had chronic difficulties in structuring and of its members, only the FN and VB enjoy a long standing presence in the EP. In the previous legislature, the ephemeral attempt to regroup (Identity, Tradition and Sovereignty) failed, only lasting eleven months due to the disagreements between the Romanian extremists and Alessandra Mussolini - this leading to the former leaving the parliamentary Eurogroup, then losing the quorum. This means that the vast majority of classic extremists are in the EP as NI: this is the case of the Martin List and FPÖ (Austria), BV (Belgium), NSA (Bulgaria), FN (France), JMM (Hungary), the PVV (Netherlands), PRM (Romania) and BNP (UK) ${ }^{77}$.

The radical left is relatively stable - with a downward tendency - in seats (41 in 2004 to 35 in 2009) and variable in votes according to the twelve countries where it is present (not an average because the decrease is only $0.4 \%$ ).

There is a significant advance in Portugal (CDU-BE and PCP), less so in France (FG) and Greece (SYRIZA), and slight decreases in Greece (KKE), Sweden (VP), Germany (DL) and Cyprus (AKEL), with the surprising disappearance of the Italian Communists. Remember that the internal structure of the parliamentary Eurogroup of this ideological group (GUE/NGL) is complex because it includes various categories. In this parliamentary Eurogroup the principal political forces are the DL, the GFR and the KSČM, being the basic common axis of demands for a strong Welfare State and the defence of an active and dynamic role in the economy ${ }^{78}$.

76 Coosemans, 2009b, p. 21-22 and 33; Bardi et al., 2010, p. 18, 26-28 and 104. Braun et al., 2010. Gagatek, 2010c, p. 37. Corbett, Jacobs, Shackleton, 2011, p. 106-108.

77 Altogether there are 28 MEPs from the NI, the vast majority (23) of the extreme right. It is surprising that, present in eight countries and in the absence of only two MEPs, it has been unable to group them together to make a Eurogroup, as this gives it a much better chance in the political arena: Corbett, Jacobs, Shackleton, 2011, p. 110; Coosemans, 2009b, p. 23-24; Coosemans, 2010, p. 107; Ennser, 2012, p. 154155.

78 GUE/NGL includes the PIE, a Europarty made up of six national parties (PCF, the Parti de Gauche, DL, SYRIZA, BE and IU), two "observers" of the same (AKEL, KSČM), a party of NGL (the VP) and eight assigned generically to the Eurogroup (KKE, PCP, SF and others): Corbett, Jacobs, Shackleton, 2011, p. 103. However, De 
In the two-dimensional space of European policy (the left/right wing horizontal axis and the supranational/intergovernmental vertical axis) apart from the NI - the EFD occupies the rightmost position on the horizontal axis and less integrative on the vertical axis, while the GUE/NGL occupy the positions more ot the left on the first axis and intermediate positions on the second (usually adopting the principle of integration, but criticises the current direction of EU policy with respect to this).

Figure 5

\begin{tabular}{|l|c|c|}
\cline { 2 - 3 } \multicolumn{1}{c|}{} & Scale right/left & $\begin{array}{c}\text { Supranational scale / } \\
\text { Intergovernmentalism }\end{array}$ \\
\hline GUE/NGL & $4.5(2)$ & $9.5(1)$ \\
\hline EFD & $11.1(2.6)$ & $4(4)$ \\
\hline
\end{tabular}

Source: Bardi, 2010, p. 25.

\begin{tabular}{|l|c|c|c|c|}
\cline { 2 - 5 } \multicolumn{1}{c|}{} & $\begin{array}{c}\text { National } \\
\text { sovereignty }\end{array}$ & $\begin{array}{c}\text { Critics of } \\
\text { neoliberalism }\end{array}$ & $\begin{array}{c}\text { Democratic } \\
\text { deficit }\end{array}$ & $\begin{array}{c}\text { Negative assessment } \\
\text { of the EU }\end{array}$ \\
\hline EFD & 30.5 & 4.4 & 7.6 & 12.7 \\
\hline GUE/NGL & 3.2 & 14.5 & 5.9 & 5.1 \\
\hline
\end{tabular}

Source: Bardi, 2010, p. 19.

In conclusion, the EFD is against the project of European integration and emphasises the critique of "permissiveness" of the Community authorities on migration. At the same time, the GUE/NGL is highly critical of the current EU, but not opposed, in general, to the principle of integration and focuses its policies on the defence of the Welfare State.

\subsection{Campaigns and national results of the radical parties}

Germany: European affairs did have an impact on the election campaign in this country and, therefore, the Lisbon Treaty, the European economic crisis, climate protection and the Turkish candidacy were discussed. The DL, which is often characterised even in academic circles as a soft eurosceptical party - defined itself with respect to this as "eurocritical": in its view, the current EU should be completely restructured (but not abandoned or, worse, dissolved) as the neoliberal course would have very negative social effects. In addition, for this party, the EU would give up their old pacifist inspiration on actually joining with and a subordinating themselves to the CFSP/ESDP and

Waele, Vieira, 2012, provided other figures: 23 national member parties and 11 observers (also included in both categories to parties from countries outside the EU), p. 80-81; Coosemans, 2009a, p. 53; Coosemans, 2009b, p. 19; Alexandre-Collier, Jardin, 2009, p. 602, Coosemans, 2010, p. 100 and 104, Gagatek, 2010c, p. 37. 
NATO, also they would suffer a severe democratic deficit. In sum, the DL requires the introduction of the referendum on European issues in Germany and a complete change of political perspective. The truth is that, beyond its strong direct criticism, the DL has not developed a credible alternative program for "their" Europe ${ }^{79}$.

Austria: both major governmental parties lost ground (there is civic fatigue of the traditional consociational model) and the novelty in radical circles was the struggle between three groups for a very similar space (the Martin List obtaining $17.7 \%$, the FPÖ with $12.7 \%$ and the BZÖ, founded by Haider, with $4.6 \%$ did not attain representation. Notice that all three radical right groups combined obtained no less than $35 \%$ ). The FPÖ carried out a strong xenophobic campaign (antiimmigrant, anti-Turkey), with a maximum emphasis on national sovereignty and the denouncing of the EU "mafia". It has therefore proved electorally profitable in Austria to maintain a hermetic defence of national identity against the alleged hyperbureaucratic "centralism" of Brussels. As a novelty - since the FPÖ party had always been very promarket - some neoliberal policies of the EU are criticised, especially those negatively affecting Austrian workers ${ }^{80}$.

Belgium: despite being not only a founder, but the base for the main EU institutions (Brussels is the de facto capital of a sort of "federal" Europe), European affairs were almost entirely absent during the 2009 election campaign. For the first time in European elections, the VBs political power stopped growing due to the intense competition with the N-VA and, especially, the Dedecker List (in general, the Belgian right, especially the Flemish community, increased their power and hegemony in the nationalist discourse of identity). The VB emphasised national sovereignty, rejected an eventual European superstate, criticised the "Eurocrats" for being opaque, inefficient and corrupt and stoked fears towards "uncontrolled" immigration and the Turkish candidacy ${ }^{81}$.

Bulgaria: national and European elections almost coincided (they subsequently did a month later) and it made the electorate lose interest. Indeed, they did not operate in the manner of mobilising "primaries", but quite the opposite, as if citizens were "reserving" themselves for the important elections to follow. In any case, European affairs did not count at all and, therefore, the European elections were simply a preparation for the national elections. After a few early years of civic hope in the EU

\footnotetext{
79 Coosemans, 2009a, p. 11; Liberati, 2009, p. 108; Brunsbach, John, Werner, 2010, p. 90-93; Packham, Klepatz, 2010, p. 5, 13, 19, 20 and 22.

80 Coosemans, 2009a, p. 13; Zei, 2009, p. 38; Kuhn et al., 2010, p. 41-43.

81 Coosemans, 2009a, p. 15; Togna, 2009, p. 46-47; Crespy, 2010, p. 9 and 13. Smets, Van Berendencks, Van Hecke, 2010, p. 47-49.
} 
(Bulgaria joined the EU in 2007) disenchantment and disinterest grew (in parallel with a profound ignorance) of Community institutions. In this election there was a general success for populists (the winner was the GERB of Boyko Berisov, the mayor of Sofia, a center-right party and member of the EPP). The NSA, which appeared in 2005, benefited from its strong populist style and mobilised the sector of public opinion that considered the transition process a failure and reflected a desire for revenge. This party emphasised national sovereignty opposed to the EU, manipulating the nationalist cleavage versus Europeanism and it did this by radicalising extremist positions with an aggressive campaign against Brussels and also against Turkey, the eternal target of Bulgarian ultranationalism ${ }^{82}$.

Czech Republic: from the outset one can not ignore the weight of vague Euroscepticism in this country, fuelled by none other than the President of the Republic, Vaclav Klaus. For this leader of the conservative right, the EU is a "germanocentric, centralising, collectivist and fanatically environmentalist" entity and although at a social level there is more diversity, such opinions cut across almost every party. The 2009 election campaign was carried out in a climate of strong demotivation after the fall of the government following a no-confidence motion (in March 2009) and the disappointing results of the rotating Presidency of the EU in the case of the Czech Republic. The KSČM, despite a slight decline, confirmed the existence of their stable and loyal electorate ${ }^{83}$.

Cyprus: 2009 European elections were held with Demetris Christofias as President, the first time a leader of AKEL had held this position. Though by a small margin, they suffered a punishment vote and finished second. In Cyprus all politics revolves around the division of the island and this has a European overtone, since only the south of the island is an EU member as representative of the whole island. The conservative opposition accused AKEL of converting itself into a europhobic group, something that this party denies because - in its opinion the key is to preserve the rights of Cypriot workers in the EU, the object of the criticism of this party being its neoliberal policies, not the integration of the island into the community. In any case, AKEL opposes any agreement regarding the collaboration of Cyprus with NATO and demands the withdrawal of Turkish troops from the island. Because of this, the debate on the issue of reunification and the Turkish question

82 Coosemans, 2009a, p. 15; Vannucci, 2009a, p. 53 and 56; Todorov, 2009, p. 702704; Lyubenov, 2010, p. 54-55; Raycheva, Róka, 2011, p. 62.

83 Coosemans, 2009a, p. 42; Sawicki, 2009, p. 219-221 (the quote from Klaus comes from here); Kárníková, 2010, p. 66-69; Negrine, Stetka, Fialová, 2011, p. 79 and 86. 
(the military presence in Cyprus, not the Turkish candidacy to the EU to which AKEL has no objection) monopolised the entire campaign ${ }^{84}$.

Denmark: The election campaign was dominated by the economic crisis and the debate about the possible entry of Denmark into the Euro - a very divisive issue. The DF gave its parliamentary support to the center-right to govern, especially on those issues in which they coincided with regard to the EU (Danish Euroscepticism is not only expanding, but it is very ideologically transverse). The DF scored a remarkable result that helped change internal balances of government coalitions and especially benefitted its anti-immigration policy ${ }^{85}$.

Spain: the campaign was absolutely dominated by the usual harsh confrontation between the PSOE and the PP and entirely focused on domestic issues. For the PP in opposition, the European elections would serve as "dry run" (that is, a kind of "primary") to the general election, paving the way for their return to power. The IU focused on socioeconomic issues with leftist solutions to attract voters disenchanted with the socialist government of Zapatero. Its proposal was to transform the EU with a strongly accentuated social redistribution and correction ${ }^{86}$.

France: in a context of economic crisis and increasingly important debilitation of President Sarkozy, the European debate was dominated by the classical issues in the country: loss of national sovereignty, negative impact of neoliberalism, the cost of the assimilation of the CEECs, foreign immigrants and Turkey. The FN, always faithful to its populist, ultranationalist discourse, obtained a negative result because it had to compete with other groups of the reactionary right that affected its electorate (the Mouvement pour la France of Philippe de Villiers Libertas - linked to the Libertas operation - and Chasse, Pêche, Nature et Traditions). The FN has repeatedly tried to lead the European far right as a whole, but it has never succeeded. By the mid-1980s of the last century Le Pen stated: "nationalists of all countries, unite". The failure of this strategy has been structural as it has been impossible so far to link supranational solidarity to ultranationalist parties. In any case, the EU considers that FN is a failed venture being contrary to national interests, which is why this party requires a reappropriation of national sovereignty and strong socio-economic protectionism, maintaining an

\footnotetext{
84 Coosemans, 2009a, p. 18; Fabrizzi, 2009, p. 61-63; Christophorou, 2010, p. 59-62.

85 Coosemans, 2009a, p. 19; Rodomonte, 2009, p. 68-71; Munkøe, 2010, p. 71-75.

86 Coosemans, 2009a, p. 21; Frosina, 2009, p. 251-254; Casal, Ferrín, Pardos-Prado, 2010, p. 167-169.
} 
aggressive intolerance of non-EU immigration (especially Muslim) and completely rejecting Turkey's candidacy ${ }^{87}$.

The PCF, which has been in constant decline since the 1980s, has managed to arrest the fall that was leading to its disappearance thanks to the coalition of the FG (on allying with Jean Luc Mélanchon's Parti de Gauche, proceeding from the socialist left) that renewed a somewhat old and very tired discourse. This group initially feared competition from the Trotskyists of the Nouveau Parti Anticapitaliste that, ultimately, had no impact. For the FG, the key would be "to change Europe" by protecting public services and ensuring the rights of workers across the EU. However, the voters of the FG are not motivated by "another" Europe because $65 \%$ of them are only interested in France's problems ${ }^{88}$.

Greece: the highlight of this election was the reversal of the two major national parties and the gains of the three minor parties. The LAOS radical right criticises the EU from an ultranationalist perspective: this party does not advocate the exit of Greece from the community, but the strengthening of national interest in the same. Furthermore, LAOS is very unhappy with the EU for failing to resolve two key foreign policy issues for Greece: FYROM and Cyprus. With regard to another issue, the Greek radical right is against Turkey joining the EU. With the Greek radical left, there is a relatively balanced competition between the orthodox communism of the KKE (usually the majority here) and the renovated postcommunism of SYRIZA that, this time (occasionally alternating leading positions from one election to another), benefited the first (although declining somewhat compared to 2004, with some relative advance for the second). The KKE's opposition to the EU is direct, bordering on Europhobia and unmitigated: in its opinion, the EU is an expression of large scale capitalist monopolies, a focus for worker exploitation and part of the new postbipolar imperialist order - hence it can not come as a surprise its request for Greece's exit. In contrast, SYRIZA declares itself pro-European, although it criticises the current EU for its neoliberal policies ${ }^{89}$.

Netherlands: the most significant outcome of these elections were the reverse of the three main traditional parties of the country and the substantial increase of the PVV radical right, which became the second political force at a national level. The campaign was dominated by fears

87 Allegri, 2009, p. 92-93; Boissieu, 2009, p. 733; Coosemans, 2009a, p. 25; Perrineau, 2009, p. 662; Crespy, 2009, p. 7; Petithomme, 2010, p. 84.

Allegri, 2009, p. 91; Boissieu, 2009, p. 732; Perrineau, 2009, p. 669 (the cited statistic is his); Crespy, 2009, p. 8; Halikiopoulou, Nanou, Vasilopoulou, 2012, p. 15-17.

89

Coosemans, 2009a, p. 26; Sterpa, 2009, p. 118-119; Vasilopoulou, 2010, p. 95-98; Halikiopoulou, Nanou, Vasilopoulou, 2012, p. 15-17. 
and civil unrest due to the economic crisis and the increasingly negative social perception of non-EU immigrants. On the one hand, Euroscpeticism is a rather recent phenomenon in Holland (mid-1990s), and on the other, the memory of the murders of Pim Fortuyn (2002) and Van Gogh (2008) influenced the rise of the extremists, the PVV of Geert Wilders. This party has successfully capitalised on fears of globalisation, enlargement of the EU to the east, immigration and Turkey's candidacy. Moreover, the PVV criticises the negative effects of the Euro and the cost for Holland - in paying its share of community solidarity, it is a net contributor. This party demands a sizeable reduction in the existing responsibilities of the EU and their return to national states, although paradoxically in the fight against illegal immigration it favours the increase in inter-governmental community cooperation. In sum, the hostility shown to the EU and the xenophobia were the two factors that contributed to the rise of the radical Dutch right. The populist denunciation of community "interference" and the lack of transparency of European institutions, along with anti-Islamic prejudice (Wilders warned about an alleged "tsunami of Muslims" if Turkey joined the EU), plus the rejection of the traditional national "political class", were skilfully exploited by the PVV ${ }^{90}$.

Hungary: the weakness of the socialist/liberal government and the adoption of harsh, unpopular economic and social measures provoked strong political tensions in the country. This explains the overwhelming victory of the center-right FIDESZ and the strong rise of the extreme JMM. On the one hand, the European elections in Hungary reflected the disappointment and general indifference towards the EU, and on the other, the campaign was totally dominated by internal political affairs. Since 2006 the JMM has become increasingly visible. It is an authoritarian and xenophobic party - neofascist by nature - and has accumulated frustrations. This party, which has recovered symbols of interwar Hungarian fascism, has today synchronised with - for example - the Magyar Guard, a neo-Nazi group that advocates expelling Hungarian Jews, gypsies, homosexuals and foreigners. In addition, the JMM message has gained acceptance: the economic crisis has worsened because the EU used the CEECs as internal colonies. However, it is still somewhat contradictory the Euroscepticism both in this party and also what is becoming widespread in Hungary. In 2001 only $13 \%$ of Hungarians were against their country's entry into the EU - with the subsequent rapid disenchantment after 2004 , by 2008 only $31 \%$ considered it positive $(22 \%$ of Hungarians have a frankly negative

90 Coosemans, 2009a, p. 37-38; Villani, 2009, p. 180-184; De Wilde, 2010, p. 1-8; Van Ham, Smets, 2010, p. 131-135. 
image of the EU). Although the central slogan of JMM ("Hungary for Hungarians") is very popular, $69 \%$ of voters in this party are against their country leaving the EU, reflecting a sort of resigned acceptance that there is no possible alternative to the current status quo ${ }^{91}$.

Italy: European elections in this country coincided with local elections ("administrative elections" in the Italian political lexicon) which involved municipalities and provinces. Consequently, once again the elections were strictly internal, an evaluation of Berlusconi, so the campaign revolved almost exclusively around this controversial leader entangled as usual in various scandals and court cases, conspicuously ignoring matters strictly European. What was noteworthy in these elections was the increase in abstention, the new triumph of right wing ( $\mathrm{PdL}$ and $\mathrm{LN}$ ) and the disappearance of the radical left, with less consensus than ever (the PRC and the Comunisti Italiani attained only $3.4 \%$, down from $4 \%$ needed to obtain representation). In contrast, the LN obtained an excellent result (it doubled from 2004) and capitalised on the protest vote (being in government, this is not without its significance). The LN is increasingly critical of the EU, but does not advocate Italy's exit from the same and during the campaign stressed the centrality of national sovereignty of States against Brussels, barely mentioning Europe in its campaign, focusing almost exclusively on internal affairs ${ }^{92}$.

Portugal: the entire campaign focused on an intense debate on the severe internal economic crisis and the results meant a net loss of socialists in government and a clear triumph for the right wing. The radical left did achieve significant progress and in the struggle between the two, on this occasion the BE (which doubled its results compared with 2004) marginally advanced the CDU-PCP. Both parties harshly criticised the EU and manifested opposition to the Lisbon Treaty. Both aimed to defend the rights of workers and demand stronger government regulation of the economy ${ }^{93}$.

UK: Since 2005 British politics have experienced leadership changes in the major parties. In the conservative party, Howard was replaced by Cameron in 2005, in the Liberal Democrat Kennedy was succeeded by

91 Coosemans, 2009a, p. 27-28; Pancheri, 2009, p. 267-268; Todorov, De Waele, 2009, p. 710, 715 and 718; Batory, 2010, p. 102-104; Heller, 2010, p. 11-13, 15-16, 18 and 20-21; Raycheva, Róka, 2011, p. 65.

92 Coosemans, 2009a, p. 30-31; De Winter, Gómez-Reino, 2009, p. 641; Rodomonte, Rosa, Sterpa, 2009, p. 134-136, 138, 140 and 142; Bressanelli, Calderaro, Piccio, Stamati, 2010, p. 113-115; Roncarolo, 2011, p. 136-139.

93 Coosemans, 2009a, p. 40-41; Cassetti, Ricci, 2009, p. 202-203; Santana Pereira, 2010, p. 144 and 147. 
Campbell who, in turn, would be replaced by Clegg in 2007 and the Labour Party Blair passed the baton to Brown in 2009. On this occasion, the European elections coincided with local elections, two particular events that usually do not mobilise the electorate in this country. The economic and financial crisis and tensions in the Brown government made the whole campaign revolve around these issues, with Europe completely out of the debate. As a consequence, the elections were an evaluation of the Brown government and in this sense, the result was disastrous for Labour since they were relegated to third place, behind the europhobic UKIP (in votes not in seats, as they tied in this case). This party was one of the big winners of the elections and their excellent results confirmed the solidity of Euroscepticism in the UK. The UKIP is a monothematic party whose objective is almost exclusively to get the UK out of the EU because, in its opinion, the EU imposes "illogical, bizarre and wasteful" policies on the British people, ignoring public opinion and without allowing citizens to pas judgement on the same. For the UKIP, the EU is ruinous for the UK and exacerbates corruption in public life. Although its rhetoric contains some xenophobic overtones, the UKIP has sought to expand its electoral influence through arguments that emphasise national sovereignty against Brussels. $69 \%$ of the voters of this party express their refusal to continue maintaining current British links with the EU and $82 \%$ strongly support the exit of the UK from the community. This thesis matches the classic far right stance of the BNP, that, for the first time, obtained no less than two MEPs ${ }^{94}$.

In the case of Northern Ireland, this has its own political dynamic with a different party system and the significant novelty here was represented by the historical fact that the primary political force in the territory was the SF. All things considered, affairs of a strictly European nature played a very minor role in the campaign ${ }^{95}$.

Romania: the country has a magmatic and personalist party system with habitual political defections - this time, with the change of the electoral formula (proportional with the possibility of personal selection of candidates), the results benefitted the PRM. Indeed, this party - that had lost representation in the national parliament in 2008 - would maintain this in the European elections of 2009 and this despite having to compete for space with the clearly neofascist radical right Noua Dreaptă party. Despite the strong ultranationalism of the PRM, it is in

\footnotetext{
94 Coosemans, 2009a, p. 44-45; Clementi, 2009, p. 210-211; Hanley, 2009, p. 671, 677679; Carter, Loomes, Landberg, 2010, p. 178-181; Michailidiou, 2010, p. 10 and 16; Negrine, Stetka, Fialová, 2011, p. 79 and 87.

95 Clementi, 2009, p. 212; De Winter, Gómez-Reino, p. 2009, p. 638; Carter, Loomes, Landberg, 2010, p. 181.
} 
favour of Romania's membership of the EU and, in fact, European affairs had little impact during the election campaign. The PRM reiterated its nationalist ideology, emphasised the Christian character of Romania and populistically championed a strict policy against generalised corruption ${ }^{96}$.

Sweden: European issues are important in Sweden and are very divisive politically. In the parties critical of the EU there were populist parties that stood out (the Pirate Party) and although the radical left retained its European representation, it experienced a significant decline (more than seven percentage points), reflecting the electorate's shift to the right with respect to this. The VP is very critical of the EU and doctrinally defends Sweden's exit from the community, although in its practical policy it accepts the reality of membership ${ }^{97}$.

Coosemans, 2009a, p. 43; Vanucci, 2009b, p. 229-231; Todor, 2010, p. 149-153.

97 Coosemans, 2009a, p. 49; Mezzanotte, 2009, p. 260-261 and 264; Joensson, 2010, p. 172 and 175 . 


\section{CHAPTER III \\ Election Manifestos and Programmes}

In both ideological groups of parties the same items are analysed in their election manifestos, but for both the order of items varies in their presentation, depending on the quantitative relevance offered in the texts. With three dimensions (national sovereignty/democracy deficit/ neoliberalism) the placing of the second never changes, but the first and third do: for the radical right the presentation order is national sovereignty/democracy deficit/neoliberalism, while for the radical left it is neoliberalism/democratic deficit/national sovereignty. Indeed, national sovereignty is a core issue of the radical right and its study focuses on two areas: the general rejection of the supranational EU policy and the migration issue (with the additional question of Turkey) as these form part of the "hard core" essentialist discourse of the radical right in relation to the bulk of its criticism of the EU. This does not detract from the fact that it also severely judges democratic shortcomings in the community and even its neoliberal policies for being prejudicial precisely for the national interest. In contrast, criticisms from the radical left focus on the direct denouncement of the EU's current social and economic policies and their excessively discriminatory consequences for citizens. The democratic deficit of the EU is the main reason for considering the principle of national sovereignty actual and defensible which needs to be linked to popular interests.

One must bear in mind that the electoral manifestos of the 22 selected parties are very different both for their quantitative extension (although, in general, they are rather brief) and in their qualitative scope given to some or other items. In addition, the letter fonts and spaces vary, as well as the fact of having graphic illustrations or not, hence the indicator of their reach should be observed with some caution. In general, it is evident that the manifestos of the radical right are shorter, while the radical left tend to be longer and more extensive. 


\section{Table 1}

Radical right (number of pages from lowest to highest):

PVV: 1

VB (b): $1 *$

FPÖ: 2

UKIP: 2

LN: $3 * *$

LAOS (b): $3 * * *$

PRM: 3

FN: 4

DF: 6

NSA: 9

LAOS (a): $24 * * * *$

JMM: 56

VB(a): 145

Real Total: 117 pages.

* Programme for the European Elections 2009

** Programme for the local and European elections 2009

(The text has 63 pages of which three are on the EU)

*** Foreign Policy Programme

***** European Elections Programme 2009

***** Flemish Programme for the 2009 Election

(includes 3 pages of scattered European references)

\section{Table 2}

Radical left (number of pages from lowest to highest):

KSC`M: 2

AKEL: 5

FG: 5

SYRIZA: 9

VP: 9

CDU-PCP: 12

SF: $15 *$

BE: 16

KKE: 21

DL: 24

IU: 52

Real total: 170 pages.

* The English version occupies 15 pages and Gaelic and the other 15. 


\section{The Radical Right}

\section{National sovereignty}

\subsection{The rejection of political federalism}

- The PVV is completely opposed to a possible European super-state as "nobody wants a supranational state. [It would mean] even more bureaucrats, more regulations, more taxes", hence it only supports economic cooperation, strictly delineated through specific, independent treaties.

- For the UKIP the EU is a unbearable corset for the UK and so defends its proposal for the UK's exit from the same since "leaving the EU will allow us to regain control and put British interests in front of European interests". Its economistic criteria is unmistakable: "We want a friendly relationship and free trade with all our neighbours, but NOT [sic] a political union". Consequently, the "UKIP believes that the UK should leave the EU and our current membership should be replaced by a genuine free trade agreement similar to that enjoyed by other nonmember nations of the EU such as Switzerland, Norway and Mexico".

- The VB criticises the Lisbon Treaty because with it "the evolution towards a federal Europe has been strengthened" and that "we are against the European super-state which intervenes in all competences of member-states: the Nation States must remain the cornerstones of any future European collaboration" (VB b). For the VB the key is "the protection of Flemish interests, national sovereignty, the right of selfdetermination" which could fit into "a confederal Europe, in which the states retain their sovereignty" (VB a).

- The opposition of the JMM to the EU is very articulate, as is its alternative proposal, and both premises are based on the radical defence of the ever prioritised national interest. The JMM explicitly aligns with the forces "called Eurosceptic" that want to counter the dominant EU line favouring maximum supranationality: [the EU] "is already positioned over the states" and is heading towards the European super-state, making national independence impossible, a scenario that "must be rejected". Indeed, for the JMM, "the central power of Brussels and the political elite that is linked to it (...) is planning to open the way for the United States of Europe, which will finally eradicate national states". According to this political group, the pro-EU Hungarian parties have hidden the fact that integration would mean "giving up a large part of national independence". After regaining freedom with the disappearance of the Soviet empire, now Hungary is being required to voluntarily give up its independence. Consequently, "a solid federal system of 
bureaucrats, like a new breed", has been created - strengthened by "the Treaty of Lisbon (...) [that] could be described as an important stage in the process of European empire building".

From this diagnosis, the JMM believes that there is an alternative to the current EU: the "Europe of Nations" in counterpoint to the project of political union. This party supports "flexible forms of economic cooperation" meanwhile the right to self-determination and national sovereignty is respected. In its view, "Euroscepticism" is in reality "Eurorrealism" because "the peoples of Europe do not want to be part of an empire". In short, the JMM argues that Hungary's national interests could be better defended with its proposal, in line with its nationalist ideology, offered in the benefit not only of all citizens of the Republic of Hungary, but also for "all Hungarians living in national regions that have been separated from the country". This is what leads it to demand a closer cooperation between the CEECs because objectively they have common interests to defend against the current EU.

- According to the LN, the EU unceasingly increases the centralisation of power in Brussels, with its "top down" decision making process without the consent of the people. The European integration process "is leading to a real and strictly continental super-state, whose democratic level, in fact, is nonexistent". The LN opposes this "intrusive" EU and warns "of the danger to European peoples due to the imposed homogenisation by the Community institutions". In this sense, this group states with determination that they "absolutely do not want to make the EU states "disappear" in the name of a supranational principle". The LN is now habitually classified as a "eurosceptical" group, something that it no longer rejects, "perhaps because of these 'eurosceptical' positions, Europe is starting to discuss the revision of itself".

In any case, the LN stated that "it is not against Europe in itself" and admits that there are common elements of identity, but this cannot lead to uniformity. On the one hand, the LN advocates the necessary formalisation of the "Christian roots" in European treaties, and accepts the strictly confederal institutional embodiment of the same. In effect, the LN confirms adherence to the principles of subsidiarity and solidarity traditionally wielded by the Catholic Church's social doctrine and therefore states that "the Christian roots of our continent are the real glue that holds European peoples with diverse languages and traditions together". With this, the LN requires the protection of the traditional family and roundly rejects any supranational provisions recognising unions of people of the same sex. Finally, the LN may accept an EU of strictly inter-governmental cooperation: "We want an EU based on a confederal model in which the member States maintain their own 
sovereignty unchanged and where the particular Regional and territorial specificities and differences are recognised".

- For the DF it is impossible and absurd to try to unite the EU with one policy given its substantial internal differences, "the DF is opposed to treating all people equally and against destroying the cultural and religious bases or creating a new European people. It may sound tempting, but it is not the way and can not be forced". This party is against the regulatory expansion of the EU and opposes the possibility that this would in itself entitle the imposition of taxes on citizens of its various countries. So, "any attempt to create a European Constitution should be rejected" because that would mean that "a federal State would remove power from European peoples and create a small, only formally democratic elite, utterly remote from citizens".

The DF, however, could accept intergovernmental economic cooperation with full respect for the sovereignty of States. In addition, in security matters, it would even be convenient to strengthen this cooperation in the fight against terrorism and organised crime, but without leading to the creation of a European police force that the DF rejects. Apart from that, according to this party "military security in Europe can only be preserved through cooperation in NATO". In summary, for the DF the Danish Constitution must be above the regulation of the EU and Denmark has to preserve its right of veto and its capacity to decide essential issues for itself. The functions of the EU should be limited only to those issues in which the majority of the population of the member countries agree to delegate, for those tasks of a cross-border nature which may require common solutions and for mutually beneficial areas.

- The FPÖ argues that Austrian parties of the establishment "want the transformation of the EU into a centralised state (...) with Austria losing its freedom and neutrality". The party defends the need to call binding referendums for any amendment of the Treaties, guarantee the maintenance of Austrian neutrality, keep Austria's veto in community affairs and, of course, calls for a "Europe of nations" versus a "federal State designed by Brussels". Also, as nationalist party, it is concerned about the fact that the German language is receding in EU institutions in favour of English and even French. For the FPÖ German should be preferred working language in the EU along with the other two mentioned.

- The NSA defines itself as a Bulgarian nationalist party whose purpose is to unite all ethnic Bulgarians and those of Bulgarian conscience [sic] - its main demand being to ensure national independence (its central slogan is "Give back Bulgaria the Bulgarians!"). The NSA is 
against all international and supranational organisations that limit the sovereignty of the Bulgarian state and threaten whole sectors of economy with ruin. National reconstruction has to reinforce the character of Bulgarian as an official language in the country and the fundamentally central role of the Orthodox church has to be recognised.

- LAOS feels fully identified with the "eurosceptical" group in which it is integrated in the EP (this is the party that does not have the slightest inconvenience in being characterised as such). From their point of view, "Greece must preserve the right of veto on issues of vital national importance" (LAOS b). In any case, this party does not advocate a disengagement from the EU, given certain conditions:

We believe the future of our country is significantly associated with the EU and we support the integration of all European countries into a viable Union, something only possible If this is established as a confederation where historical, cultural and national roots and in particular the specific national characteristics of the peoples of Europe are protected. We believe in a Europe of nations. (LAOS b)

Finally, the particular nationalist obsession of LAOS is its radical opposition to the possible entry of Macedonia (the former Yugoslav Republic this party always calls Skopje, the name of the capital): "Macedonia" would be a "denomination of origin" whose ownership corresponds exclusively to Greece. Furthermore, according to LAOS, "Skopje" would not adequately protect the rights of its ethnic minorities and while the denomination of Macedonia is not removed (not even FYROM is accepted by this party) nothing can begin to be negotiated (LAOS a).

- The PRM is limited in its brief manifesto to asserting a defence of national sovereignty: on the one hand, this party commits itself to "be firm in negotiations with the EU to obtain equal opportunities for Romania compared to other Member States" and on the other, to "maintain and promote Romanian identity, traditions and customs."

- For the FN the EU represents a mortal threat to the peoples of Europe, "the Europe of Brussels has not been an effective (defensive) barrier for our nation and its citizens, on the contrary, it has been the cause and factor of aggravation". The FN "says the way forward is not that of Euroglobalism in the hands of a small group that is recruited by co-optation: "Eurocracy"; this is not the way of the "European Soviet Union" (emphasis on the original). So, the FN is radically against a European superstate since this would destroy identities, sovereignty and freedoms of the people:

National entities resolutely combat criminal EU developments. This rejection of a Euroglobalist Super-State is in accordance with the true 
European tradition since Europe (...) has invented the freedom and equality of nations (emphasis on the original) (...) Yes, Europe and the world still needs France!

As a logical corollary of this ultranationalist thesis the FN rejects both "European citizenship", much like the CFSP/ESDP: first, national citizenship should be preserved at all costs against the risk of a possible "absorption" into a "European citizenship", embodying the submission of nations and secondly, the current foreign and defence policy of the EU leads its members to participate in "conflicts that are not ours, such as the absurd wars against Iraq and Serbia".

The FN claims to have "another" idea of Europe "the right direction excludes neither European consultation nor industrial, cultural or other cooperation. But it implies a radical break with the global system" (emphasis on the original). In this sense, this group asserts that "the French FN patriots (...) are not 'against Europe' as a geographical, human or cultural reality, or against any form of European cooperation" because they acknowledge that, despite its profound diversity, there is "a certain common cultural heritage of the peoples of Europe". Its proposal is that of a "Europe of nations" giving full guarantees to its people: "Europe can not be strong if the Nations [sic] that constitute it are not also strong, prosperous, independent, sovereign and respected". Of course, this essentialist revaluation of the national bases of the peoples of Europe means that the "moral and spiritual values" of Christian roots must be faithfully respected.

\section{Table 1}

Primacy of National Soveriegnty

Christian roots

$\begin{array}{ll} & \text { NSA } \\ \text { FN } & \\ & \text { PVV } \\ \text { VB } \\ \text { JMM } \\ \text { LN } \\ \text { DF } \\ \text { FPÖ } \\ \text { NSA } \\ \text { FN }\end{array}$

All

LN

NSA

FN

PVV

$\mathrm{VB}$

$\mathrm{N}$

$\mathrm{F}$

NSA

$\mathrm{FN}$ 
Yes to a European confederation

of intergovernmental cooperation
VB

JMM

LN

$\mathrm{DF}$

LAOS

FN

Abandon the EU

UKIP

\subsection{Turkey and non-EU immigration}

- The PVV is opposed to further enlargement of the EU, "the European Union is too big. Enough. Each new member means more money for Brussels and a decrease in Holland's power to decide. So there should be no further accessions to the EU. Corrupt states like Romania and Bulgaria have to be expelled". In any case, the maximum hostility this party has is focused on Turkey: the intro title of its programme dedicated to its nomination is entitled "Turkey will never be welcome". The PVV argues that by 2050 there will be a hundred million Turks and that their state, as a member of the EU, will dominate Brussels, supposedly a very damaging scenario for Europe and the Netherlands. Consequently, "as we in the PVV say: Turkey will not be an EU member now or in the next hundred years. Islamic culture is a culture diametrically opposed to ours". For this party, It is precisely in this last Islamophobic consideration the central justification of its exclusionary criteria resides.

The intro title of the PVV's program dedicated to immigration is entitled: "Eurabia or Europe?" (Confusing, incidentally, what is Arabic and what is Muslim). In parallel with the routine strategy of populist parties of the radical right, immigration, Islamisation and insecurity are associated - "mass immigration and Islamisation are a disaster for Europe and the Netherlands. The Islamisation of Europe and the Netherlands has to stop. So we want to decide who to admit and who not to. The right to veto on immigration must be maintained. In our country, we decide. There is enough Islam in Holland".

- UKIP rejects the open-door policy with regard to the immigration, "the expansion of the EU encourages uncontrolled immigration (...). Our public services are crumbling under the pressure of more than a million people who have come to our country".

- The VB states that "Turkey is not European but Asian. Turkey is an Islamic country that is not part of the European tradition" so it is necessary to "stop the negotiations for Turkey's accession" (VB b). This party uses a closed cultural argument to demand "limiting the EU to 
nations belonging to European civilization: so, Turkey can not be a member of the Union" (VBa).

Given the particularly xenophobic character of the VB (the issue of immigration is the most electorally profitable it has), it is not a coincidence that its manifesto is very detailed on this topic. For the VB: "the tide of illegal immigration is unstoppable and therefore we want a true 'fortress Europe' [sic] with impermeable borders". This party requires that regularised immigrants be obliged to integrate by passing an "integration test" [sic], conditio sine qua non to obtain the right to permanent residence. In its view, "immigrants have to adapt to our culture, our norms and values, our customs and important traditional principles that have been developed on European soil". In any case, the reception of new immigrants should be completely stopped, illegal immigrants repatriated, minimise family reunification and prevent "abuse" of asylum:

"On European soil, only European asylum seekers will be hosted" (somewhat anachronistic today with the automatic recognition of extradition between European countries). But the religious dimension is the most exploited by this party, "European states should formulate a draconian response [sic] to Islamisation and demand that Muslims living in Europe accept our values and our laws". According to this thesis, some Muslim practices "are not just different from ours, (...) they are unacceptable (...). They violate treaties on European human rights". With this diagnosis, the prescriptions of the VB are extremely restrictive and, indeed, many of them are contrary to Community treaties: withdraw recognition and subsidies for Muslim centres, ban the veil in public facilities, reserve job vacancies in the public sector for nationals, limit the free movement of people, abolish dual citizenship, prevent foreigners from voting in municipal elections and encourage repatriation agreements with third countries (VB and $b$ ).

- JMM only mentions minority issues with regard to one group inside the country and very relevant to Hungary: the Roma gypsies. The party rejects the official policies of positive discrimination for this group and that - in its opinion - the promotion of the Roma in education and employment should be done without the privileges that the current formula provides.

- The LN says that Turkey has no "European features" theirs being far from what is common in EU States. The LN cites Giscard d'Estaing and Angela Merkel as authoritative sources for the rejection of Turkey's candidature, adding that Turkey's democratic standards are notoriously inadequate. However, the $\mathrm{LN}$ asserts that there are powers outside Europe, such as the U.S., who would be the most interested in such an 
outcome. From this viewpoint, it would be a totally conditioned guarantee to expand its strategic influence in Europe and weaken it even further. With this in mind, the LN adds two additional issues: Christian roots and polls. With the first, "Turkey's entry into Europe would also provoke the collapse of the very concept of a Europe based on certain cultural and spiritual roots. Roots, we repeat again, that are Christian [with a capital "C"]. With the second, all the polls confirm that the majority of citizens reject the accession of Turkey - as opposed to the "political class" - and not to satisfy their demands would be undemocratic. On immigration, the $\mathrm{LN}$ demands well regulated movements not only for economic factors, but also for social and cultural considerations with an increasing trend towards border closures.

For the DF the constant enlargement of the EU is making the decision process increasingly difficult. The DF is concerned about the incorporation of new unstable States and, in any case, is opposed to integrating countries alien to "Western culture." The DF believes that the strategy of enlargements is an attempt to create a European federal state, even though - in practice - this increasingly complicates the deepening of integration. This party argues that Turkey "is not a European country and [its] culture is incompatible with Europe". Randomly combining geographical, cultural and social arguments, it states: "Turkey belongs to the Middle East and its citizens are not European. Turkey is influenced by culture and social norms that are far from Europe and this is reason enough to refuse it membership of the EU". To more fully justify its rejection, the DF mentions the situation of women, occupation of northern Cyprus, high corruption, weak judicial independence, torture and denial of rights to ethnic minorities. Moreover, given its high population growth, in 2020 Turkey would be the most populous state in the EU and this would have an unbearable economic cost given its enormously underdeveloped agriculture. In conclusion, the DF agrees to increase cooperation with Turkey, but not incorporating it as a community partner.

According to this party, the EU immigration policy is totally misconceived because you can not open doors to people foreign to Western culture without their at least acquiring a minimum knowledge of it. Because of this, the EU policies of always attracting new waves of immigrants will cause "an unprecedented chaos" and also "attract less qualified people". Again the usual Islamophobia blooms in this party when it asserts that "increased immigration into the EU will lead to a devastating Islamisation of Europe". To sum up, "the DF believes that Denmark should maintain its right to ensure its own independent immigration policy" and, beyond this, that it must be the whole EU that stops the new influxes. 
- The FPÖ argues that "Europe must end at its geographical borders", an entirely arbitrary and useless conventional criteria because of its impossible objective determination. Its position is to immediately stop negotiations for Turkey's accession to the EU. Its main critical arguments are concerned with certain international guarantees of Turkey with regard to the alleged dangers of Islam. In the first case, defending Turkey's candidacy would be to convert oneself into a "henchmen of U.S. interests". In the second, radical Islam and illegal immigration are associated with Turkey in a biased and unprovable way - for the FPÖ those who defend its candidacy provoke a return of radical Islam in Europe and mass emigration of Turks into Austria, with negative consequences for the people" and even for all the "Christian West". Therefore, the sequence for the FPÖ is clear: Turkey's accession would be a boon for radical Islamism and uncontrolled immigration. Consequently, the FPÖ demands the holding of a referendum in Austria on the possible incorporation of Turkey into the EU for the people to decide and that, from their perspective, you can not keep taking decisions of this calibre from behind citizens' backs. In any case, you could offer Turkey a partnership agreement, but never integration.

For the FPÖ, on one hand, costly social benefits for those from outside the EU should be cut and on the other, the open door policy that has caused the increase in crime in Austria needs to be stopped: "Spain legalised thousands of illegal immigrants overnight who now can move freely throughout the EU. Since then, East European gangsters and bogus asylum seekers, who are actually criminals, bring muggings, robberies, the drug and human trade to Austria". The FPÖ demands the reintroduction of border controls in the east, the expulsion of all nonnative criminals and facilitating the acquisition of weapons for Austrian citizens, this last being a disturbing demand that favours private self defence over public safety.

- The NSA does not mention Turkey explicitly in its manifesto, but does include a mention of an internal regulation affecting the ethnic Turkish minority in Bulgaria, "Ataka proposes as its main purpose the suspension of the Islamisation of Bulgaria" and adds that building strictly non-Christian religious temples must be regulated.

- The LAOS is against Turkey joining the EU because it invaded northern Cyprus and that it continues to deny the Armenian genocide. From these premises, this party feels that negotiations with this country can not even be started. On other issues, the LAOS added that Turkey does not meet the minimum economic conditions for their integration in the EU, even with long transition periods (LAOS a). 
- For the FN,

the Europe of Brussels (...) is the Europe governed by technocrats remote from reality (...). It is also the Europe colonised by immigration of African or Asian origin (...), the Europe in the process of Islamisation that plans to make Turkey one of its members. These are the results of the betrayal of the political classes and financial leaders and of their commitment to unbridled free trade and globalism.

Therefore, the FN rejects the candidacy of Turkey or any other "nonEuropean" country intending to join the EU. Instead, we should enhance cooperation with European nations that are not in the EU (Serbia, Ukraine, Belarus and Russia).

On the issue of migration, the FN advocates a restoration of internal border controls and rejects the European Pact on immigration for being "permissive" (despite its harshly restrictive "Return Directive") and for giving the Commission "excessive" power. According to this party, migration should be strictly restricted and must be exclusively a matter of national responsibility. With regard to other issues, the FN reaffirms its thesis of "national preference" in employment and, in all cases, prefers Community workers over foreigners.

Table 2

$\begin{array}{ll}\text { No to Turkey in the EU } & \text { PVV } \\ \text { VB } \\ \text { LN } \\ \text { DF } \\ \text { FPÖ } \\ \text { LAOS } \\ \text { FN } \\ \\ \text { PVV } \\ \text { UKIP } \\ \text { VB } \\ \text { No to immigration from outside the EU } \\ \text { LN } \\ \text { DF } \\ \text { FPÖ } \\ \text { FN }\end{array}$

\section{Democratic deficit and neoliberalism}

- For the PVV, "Holland's interests must always prevail", so this country should have the power of veto and to block EU decisions as well as a clear objective of "recovery of powers in all areas". With regards the present, this party demands that the Lisbon Treaty (which it rejects) be subject to popular referendum. After this political criticism, the PVV expresses its protest about economic issues: "The Netherlands 
is the largest net contributor to the EU. We want our money back. We want to allocate billions of Euros back to Holland and not to Brussels". In accordance with closed ultranationalist criteria, the PVV rejects the idea that Dutch money can serve "to train farmers in Poland and France" or to build roads in Bulgaria or Portugal.

- The UKIP indicates that the EU is not only economically negative for the UK, but also in political terms as it has an unacceptable democratic cost. With this in mind, it states in its manifesto that in the last twelve months about 2,500 rules have come into effect in the country ( $75 \%$ of all laws that came into force in the UK in this period), something to be rejected because - in the opinion of the UKIP - these were "impositions" of "unelected bureaucrats in Brussels". For this party, the British people have been denied a say via referendum on the Treaty of Lisbon, which is nothing more than a "camouflage" of the Constitutional Treaty rejected by the French and Dutch. The UKIP wants a UK "governed not by anonymous bureaucrats in Brussels, but by our own people through our elected parliament in Westminster" and that "the only people who should decide who can come, work and live in Britain are the British people". In sum, the UKIP creates great alarm about the supposed loss of British control of agricultural and fisheries policies, which would be ruinous to the national interest. According to this diagnosis, the UK would lose jobs and substantial funds ("the EU costs us $£ 40$ million each and every day"), so "we believe that British taxes should be used in Britain".

- The VB demands that key decisions such as the accession of Turkey or further transfers of sovereignty to the EU must always be subject to popular binding referendum ( $\mathrm{VB} a$ and $\mathrm{b}$ ). In economic affairs, the VB argues that Flanders should be one of the primary regions of the EU - this being blocked by some of its policies. On one hand, the VB requests the application of reduced VAT in some areas, and on the other, not to reduce the community measures for agricultural support in the face of international competition, to maintain subsidies to fishermen and to make the PPC more flexible (VB a).

- For the JMM, the EU works undemocratically, is bureaucratic, corrupt, anti-national and neoliberal: the Lisbon Treaty basically amputated national sovereignty, reduced democracy and erased the content from the European social model. According to this party, the EU is not democratic and is not governed by the classical theory of the division of powers, it is hyperbureaucratic, given the overreaching power of unelected decision makers in Brussels, it is unable to eradicate corruption (citing the case of the Santer Commission, despite being exonerated by the report of the "committee of wise men"), agrees to 
accept States into the union that recognise same-sex marriage that undermines the traditional family model, admits no criticism of its policy on immigration, automatically disqualifying this as xenophobic and considering racist those who reject positive discrimination for the Roma (the case of the JMM). On one hand, the JMM criticises the Hungarian establishment that has submitted itself to the ordinances of Brussels and has disengaged itself from people's problems and is disappointed with the EU after entry and on the other asserts that it is unacceptable that EU law directly meddles in the internal legal order, assuming a position superior even to the national Constitution. The JMM opposes the neoliberal policies of the EU, a model that favours market concentration in a few large corporations. Such guidelines are designed by technocrats serving multinational companies whose deregulatory, liberalising and privatising policies have mined social and economic sovereignty. For the JMM, the EU falsifies the market and serves US centralised globalised finance - increasingly resembling a multinational neoliberal empire. This party asserts that the majority of Hungarian society feels cheated and deceived after the country's entry into the EU because the "political class" of the establishment drew an idyllic picture that has not been fulfilled at all, silencing opponents at the same time. Subsequent developments have confirmed that the promises of welfare and progress were a crude manipulation. Therefore, all Hungarian governments are responsible for accepting unfavourable terms of accession that have sacrificed national interests. In this general criticism, the JMM includes not only liberal forces and the postcommunist left, but also the parliamentary right, which has been coresponsible for a capitulation of such a manner that all political groups function as a "single pro-EU party". According to the JMM the conditions of accession of Hungary should be thoroughly reviewed as the current situation is very negative for national competitiveness, the "SMEs", workers and internal production in general being increasingly marginalised and defenceless against the a flood of Western multinationals. In summary, the EU does not promote truly equal competition, suffocates the system with bureaucratic regulations and does not act democratically. The JMM claims that Hungary has lost national territory (26\% now foreign owned), does not protect farmers from a CAP that only favours large agroindustrial entities, has not been able to open the labour market in Germany or Austria to Hungarian workers and has placed the country at the service of multinationals. The EU has not even been able to secure the rights of Hungarian minorities in neighbouring states. In conclusion, Hungary as a country has lost out in joining the EU and has been colonised in the same way as all the countries in the CEE area. 
- For the NL, the 2008 Irish referendum was to be yet again a reiteration that the distance between the people and the EU had been confirmed, "the EU today is structurally based on a real and strict democratic deficit" (underlined in the original). In its view, "the progressive transfer upwards of sovereignty and powers is contributing to the removal of the voice of the people of Europe". The remedy the LN proposes is the absolute respect for the principle of subsidiarity: "no European regulation should be adopted when this same regulation may be decided by the States (or regions with legislative powers)". In economic affairs, the LN is against "bureaucratic regulations" and unfair competition, while defending the revaluation of traditional local products.

- The DF argues that various referendums have shown the growing separation between Brussels and citizens - something due to the inability to democratically control EU decision makers given the lack of real supervisory mechanisms. According to this party, Denmark can not accept intervention in its internal affairs from the outside, nor the waste of public money due to the irresponsible management, corruption and despotism of the EU. The elites have hijacked decision making against society's interests, national democracy is in danger because of this process and citizens have not the slightest chance of influencing this. Consequently, the DF always demands referendums for any further transfer of powers to the EU, whose powers should be limited and, in part, renationalised. Although the DF recognises that the EP has increased its powers of control, the party is against its growing legislative function. On the one hand, "the DF does not see the European Parliament as being representative of citizens even when imposing its own rules" and on the other, "does not want it (...) to have legislative functions". The party indicates that the PE favours greater integration, far beyond what people want, its "legislative interference" is inadmissible and that it violates free cooperation between sovereign states. In summary, the DF proposes cutting the powers of the Commission which should be reduced to mere administrative body - and increase the Council of Ministers which oversees national interests.

For the DF it is inadmissible to share a common currency between countries that have carried out economic reforms and others who have not done so, since this harms the former, like Denmark (though not in the Euro). In any case, the DF advocates a drastic cut in community budgets.

- The FPÖ demands ongoing binding referendums on EU treaties and advocates radically dismantling Brussels bureaucracy. At the same time it rejects the neoliberal policies that only serve to benefit the interests of big business. In its view, the bank is responsible for the current crisis 
and "the EU means globalisation at any price". More particularly, the crisis has been caused "by profit seeking, pure and simple, the withdrawal of security measures, an irresponsible extension eastwards including doubtful trading and an almost servile alliance with the U.S.”. Consequently, the EU has not protected their countries from the catastrophic consequences of the economic crisis" and therefore "Brussels is the cause of mass unemployment and bankruptcy". With this grim diagnosis, the FPÖ states that "the change in the EU should not be determined by corporations, but with the effort of social security". For this, the transitional periods for the Austrian labour market should be broadened, tax havens frozen, the unconditional alliance with the U.S. ended, Austrian banking secrecy maintained, the national contribution to the EU cut and the country's best assets not sold off. The FPÖ's prescriptions seek to protect the domestic market and the interests of Austrian workers, reducing the net contribution of Austria to the EU by half, since the current level is notoriously unfair to the country - being also uncontrollable (in its view, many funds are squandered in corrupt Eastern european countries) - and to radically cut covert immigration, repatriating the foreign unemployed.

- For the NSA Bulgaria is at the bottom of income ratings for the EU because of the unrestricted application of a ruinous economic model imposed by the same, "the time has come to declare the end of neoliberal speculation". The party supports "a state policy of recovery of lost markets for Bulgaria outside the EU" and requests the creation of a special agency to manage non-governmental EU funds transparently. Finally, "Ataka considers the revision of all agricultural production quotas with the EU necessary because they do not correspond to the real possibilities of production in Bulgaria and are damaging our country".

- The PRM defends the promotion of Romanian products inside and outside the country and the prevention of domestic prices rising above the EU average. It also demands the receipt of "urgent and warranted" new community funding and specifies that this has to be three times what Romania gives to the EU. Also, the PRM seeks more EU grants for Romanian agriculture and demands that transitional periods that impose restrictions on Romanian labour within the EU are withdrawn as soon as possible.

- The FN demands that any new EU treaty or any new accession must necessarily be subject to a binding national referendum. In any case, it stands against the Lisbon Treaty that has betrayed the popular mandate of the majority of the French, Dutch and Irish. For the FN national law must always prevail over that of the community and States must be able to veto regulations set in Brussels. In the economic sphere, 
the FN proposes the establishment of limiting import quotas in areas of special interest to France, advocating the reintroduction of the Franc and leaving the Euro as merely a virtual common unit, rejecting any transfer of financial authority to Brussels, as well as creating a European tax, declaring itself against the Community directives on hunting and fishing and condemning the "stupid" [sic] Stability Pact.

Table 3

The EU Treaties must always be subjected to a popular binding referendum

PVV

UKIP

$\mathrm{VB}$

DF

FPÖ

$\mathrm{FN}$

The EU institutions are not democratic

JMM

LN

DF

Community law can not be superior to national law

UKIP

JMM

DF

FN

Neoliberal policies are ruinous for national interests

PVV

UKIP

JMM

FPÖ

NSA

PRM

\section{The balance of radical right parties}

The large amount of text dedicated to the myth of national sovereignty in the programmes of this ideological group stands out: not only does this dimension occupy about half of all the manifestos, but it is ideologically their raison d'être. In some cases, the emphasis on nation - usually with strong ethnic connotations - is reinforced with ideological reference to "Christian roots", a clearly controversial element in counterpoint to the Muslim world and immigrants of this religious denomination. It is a kind of instrumental "neoconfesionalism' that pays electoral dividends for these parties in some countries.

This group resoundingly, massively and directly rejects a supranational European political union as they attribute every possible vice to this eventual European "super-state": political centralism, administrative bureaucracy, undemocratic technocratic elitism, globalised economic 
intrusion and cultural homogenisation. Instead, most are willing to accept the maintenance of mutually beneficial economic ties, but always from an intergovernmental perspective respectful of national sovereignty. Moreover, several parties even explicitly pronounce in favour of a loose confederation of independent states which could embody a true "Europe of Nations". Only the UKIP maintains an eccentric position given its strategic option of leaving the EU as soon as possible.

The majority are very hostile and aggressive with the rejection of any eventual Turkish accession to the EU, a possibility that is filled with shades of the apocalypse: it is a country that would benefit from a representation in EU institutions given its huge population, it would claim almost all the structural and cohesion funds due to its serious economic backwardness, "it would flood" Europe with hundreds of thousands of immigrants and, especially, encourage the expansion of Islamic radicalism. Turkey and non-EU immigration are precisely two sides of the same propaganda strategy of these parties: they are stoking fears and resentments with a populist and xenophobic tone that in themselves provide electoral dividends. It is usual in this media to link immigration, crime and even terrorism for such reasons. Some of these parties are notoriously demagogical on illegal immigration and its allegedly "unbearable" cost to the public purse and public safety. Naturally these obsessions are characteristic of radical right parties in developed Western Europe - it is not the same with parties of this ideology in the CEE where the phenomenon of receiving immigrants from outside is virtually unknown given the under-development of these countries.

In keeping with the traditional distrust of the radical right parties in representative institutions, it is no coincidence that several of them demand the use of direct democracy for any reform of the Treaties and/or accession of new members. From their point of view, European leaders reiteratedly contravene the desire of various sectors of their populations who have had occasion to speak out negatively about certain community projects. The fact that the "political class" of the establishment always looks for ways to circumvent and even infringe some referendum results is an irrefutable testament to the undemocratic and anti-popular parties that encourage them. From these premises, the Community institutions are severely judged, denouncing them for bring grossly undemocratic, opaque and elitist. There are several parties of this ideological group that claim such institutions are unrecoverable and advocate a maximum strengthening of national control mechanisms to prevent anonymous and irresponsible "Brussels bureaucrats" taking decisions over national interests. 
Finally, it is of great interest to analyse the economic criticism of the mostly neoliberal policies promoted by the current EU as this partly refutes certain topical viewpoints about such parties. Indeed, radical right-wing parties are traditionally attributed with a clear preference for free-market economic policies, perhaps coloured by conceptions of protectionist domestic production and commercial sectors. However, in the manifestos of 2009 there are repeated criticisms of financial globalisation and neoliberal economic policies that are deemed very harmful to national interests and are criticised for only benefitting multinational corporations and harming the great majority of people. Not surprisingly, critics of neoliberalism are particularly harsh with parties in the CEEC - socially very affected by them -, but the novelty is that many parties of this Western European ideological group reject the economic model that the current EU has imposed.

\section{The Radical Left}

\section{The rejection of neoliberal Europe}

- The SF says generally that the current economic policy of the EU increases poverty and inequality and in particular criticises EU competetion regulations for inflexibly limiting regional and local State investments. Following this reasoning, the economic agenda of the EU only benefits large multinational corporations and harms the "SMEs" and the rights of domestic workers. The SF opposes the supremacy of the market, deregulation, liberalisation and privatisation of essential public services that should strictly be the States' responsibility. With this, the party says that education, health, transport, communications, housing, water and energy are sectors that should not come under the auspices of the community. On one hand, the SF is against company relocations, and on the other, demands that European companies working outside the EU be especially respectful of labour rights and the environment.

With regard to specific policies, the SF - consistent with its nationalist ideology - demands a reform of the CAP to make Ireland's agriculture and livestock industries ecologically sustainable and socially prosperous and to provide a viable fisheries policy for the country. It then moves on to make a clear commitment to renewable energy, "we completely reject suggestions that nuclear power has a role in reducing Irish carbon emissions as it is not a safe renewable source of energy". What is then included is a specific demand of another type calling for the suspension of the preferential trade agreement with Israel while it continues the occupation of Palestinian territories. With this diagnosis, the SF focuses on prioritising the fight against poverty, inequality and 
social exclusion as an alternative as it is essential to preserve the rights of workers. The party supports a sustainable and equitable economy, based on public services, environmental protection and regional development. Community funds should be used primarily to improve living conditions in society, while promoting fair trade: "the current economic crisis requires the EU to rethink its strategy and put people's interests at the centre of its decision-making process".

- For AKEL the current economic crisis is, in fact, the neoliberal model, whose consequences are being paid only by working people. The party is opposed to the liberalisation of public services and other antisocial measures, with the alternative of preserving today's threatened social model: "a strong presence of forces of the progressive left in the European Parliament may contribute to the fight for a Europe the people rather than that of the monopolies".

- The KSČM rejects the neoliberal policies of the EU because they worsen citizens' living conditions, restricting social rights and sharpening differences. In addition, for this party, the EU imposes discriminatory conditions on the Czech Republic by limiting its agricultural production, reducing the free movement of labour and cutting funds. The KSČM demands a EU of citizens and nations with full democratic, economic and social rights. For this, goals such as job security, economic development, the end of business relocations, increased investment in education and an end to the privatisation of the public sector need to be pursued. As a consequence, banks must be regulated to limit speculative trading, energy policies coordinated, opportunities for truly free competition created (it is still striking that communists pursue this Smithian goal), tax or wage dumping prevented and way made for sustainable development.

- According to the BE, since the Treaty of Maastricht all successive European Commissions without exception have imposed neoliberal policies which are those that have led to the present social catastrophe: "Brussels is unable to agree a common strategy for relaunching the economy. The crisis demonstrates the limits and shortcomings of a European construction that unified markets, but that has always rejected the development of common policies to defend employment and improve social protection". In summary, "the crisis shows the failure of the European project as we know it. The decline of the Union, when those who suffer need it most, constitutes, in itself, the death certificate of a strategy based on the single market and currency". For the BE, EU leaders have only mobilised themselves to save the banks from collapse, while with social issues it is unable to develop common effective strategies. The BE demands that public funds supporting companies at 
the European level should depend on the maintenance of jobs, while firms receiving public assistance that relocate should be severely penalised. For the BE there is a need for a "social and democratic refounding of the European project" in order for the EU to put solidarity and employment at the centre of its policies, "the security of the Union lies in economic development, in the model of social protection, the rights offered and the solidarity promoted". As a consequence, the alternative is to promote Europe-wide anticrisis measures with more financial regulation, more transparency, more taxes for multinationals and more penalties for tax evasion, all in line with its central slogan: "We are Europhiles of the left".

- Of those selected in this research, the KKE is the party that criticises the EU more severely with an overall valuation broadly condemning all its policies. On one side, the Greek Communists claim that "the EU has nothing to do with a people's Europe", and on the other, oppose the "four community freedoms" "established" by the Treaty of Maastricht (an incomprehensible mistake as it back references no less to the original Treaty of Rome in 1957). For the KKE the EU is a "Imperialist intergovernmental union" and all its economic, political and military proposals are "reactionary". In its view, the EU only benefits big capital and is an example of worker exploitation and the miming of fundamental social rights. Consequently, the KKE asserts, "no to the EU of monopolies, capitalist exploitation, militarism and interventionism". From this approach the KKE affirms that the EU generalises redundancies in all member countries and - with a victimism linked to conspiracy theories - the KKE claims that the EU favours anti-communist persecution $[\mathrm{sic}]$ in the whole community, while objectively promoting racism [resic]. In summary, all EU policies are neoliberal and catastrophic for workers, confirming the failure of hopes in the Welfare State: a very classical orthodox conclusion about the limits of reformism.

Indeed, for the KKE "the EU can not be reformed in favour of the people (...). It is a creation of the capitalists. The peoples who want to advance must oppose the EU and its policies, disobey and in accordance with due procedures disengage from its ties". From this perspective, the weaker the EU the greater the possibilities for new forms of just cooperation between European countries to open up. So, the KKE claims that "we must weaken and overthrow the imperialist structure of the so called EU" and, in any case, disassociate Greece from it: 'Breaking the ties with the EU would be the [Greek] contribution to the international peoples' struggle". It is no coincidence that the KKE is especially critical of Greek parties that support the "pro-EU consensus" that - in its opinion - should "be punished without remorse". Though still sharing a eurogroup in the EP, the KKE is blunt with the PIE 
(which SYRIZA - the national competitor among the radical progressive electorate - forms a part) - a Europarty disqualified as an "accomplice" of social democratic governments that carry out anti-popular policies. For the KKE, the PIE will lead to the disarmament of the labour movement, the dissolution or mutation of the CPs, the reduction of their influence and strength among working people and the intensification of the EU's anti-communist and anti-socialist campaign.

So, for the KKE, only a socialist Europe would be fair, only a workers' Europe would ensure fairness and so what is needed is resistance, disobedience, insubordination and internationalist action: a classic agit-prop programme of anti-systemic confrontation.

- For the CDU-PCP, "the crisis of capitalism is also a crisis of the foundations of the EU". This is in crisis because of the neoliberal policies enshrined in the Lisbon Treaty based on deregulation, privatisation and cuts in social spending and fully in agreement with the views of the European Central Bank whose monetary policy only defends the interests of major powers. In addition, quite in keeping with its orthodox ideological doctrinaire, the Portuguese communists add that the enlargement of the EU with the CEECs has been "A reckoning with the experience of building socialism" that has destroyed its "progress" and "gains", a nostalgic reflection absent from any criticism of the old real socialism. The party argues that "European integration was never a neutral process. The EU was and is, increasingly, a tool of capital powers in Europe". In summary, the EU is in the service of the oligarchy and the powerful and is becoming a block of "imperialist character" $[\mathrm{sic}]$. For the CDU-PCP, the EU only pursues policies of exploitation, capitalist concentration and centralisation, which reveals its "class nature", in very traditional terms. The EU is deepening its neoliberal, federalist $[$ sic $]$ and military $[$ resic $]$ character, something that proves the "fallacies" of the rhetorical europhile discourse.

Portuguese Communists reject the Stability Pact and the free trade agreements sponsored by the EU, vindicating reform of European funds, the CAP and CFP to defend national interests. For the CDU-PCP the "fight against the three pillars of the ongoing process of European capitalist integration - neoliberalism, militarism, and federalism - and the construction of a workers Europe" must be undertaken. Ultimately, the CDU-PCP's alternative message is to reverse the current rightist orientation of the EU to promote social and economic redistribution, always prioritising the interests of workers and the people of Portugal, national sovereignty and interests, "for an alternative Europe of workers and peoples!”. 
- According to the IU, "the process of European integration prioritises economic and monetary union over political union and social cohesion" and also with neoliberal strategy that favours stability over employment, services and social benefits. This party approves the enlargement of the EU to include the CEEC, a real milestone, but it rejects the path chosen with the imposition of "shock therapy" that has had devastating social consequences. Neoliberalism only takes into consideration the wishes of banks and business and produces a concentration of wealth in a few irresponsible transnational monopolies. The Lisbon strategy based on competitiveness is producing disastrous social effects with public entities - that can not be regarded as commodities given their general public interest -having been privatised. So, on one hand, "the EU privatises profits and socialises losses" and on the other, "threatens public services". Specifically, the IU demands a fundamental reform of the CAP to truly favour small and medium sized farmers and the repeal of the Bolkestein directive on the liberalisation of services. The IU advocates replacing the Stability Pact for one of Solidarity since "the Europe we want requires a democratisation of the economy". The party considers "necessary restructure the EU based on new parameters, capable of focusing on people and their rights rather than private benefits", this is the only way - in its opinion - to redistribute, generate stable and quality employment, protect the environment and extend social rights. The IU criticises the larger political forces for not deciding for a strategic refoundation of Europe - this being the cause of crisis in the integration process. The alternative advocated is "a pro-European policy of the left, not eurosceptical in nature, able to change the model of the EU" and "a persistent action against racism, xenophobia, ultra-nationalism, chauvinism [any difference between this and the former is not clarified, since both are practically synonymous], fascism, anti-communism [without recognising that authoritarian communism exists], homophobia and any other form of discrimination".

- According to the DL, the neoliberal policies of the EU are responsible for the aggravation of the greatest economic crisis since the Second World War. The obsession with competitiveness sacrifices social rights: "in the EU the freedom of enterprises and capital has priority over fundamental social and political rights". Therefore, the current EU - according to the DL - "goes against the interests of the majority of the population" and also "increasingly manages the implementation of imperial capital interests". According to the party, the disturbing rise of neofascist forces in Europe is not a coincidence, it is something that should "be denounced and fought against without reservation". The DL opposes deregulation - privatisation and liberalisation always affect key sectors and basic services and it demands the "highest priority for the 
protection of public property". In specific sectors, the DL rejects EU policies on development cooperation given that these have not promoted fair trade, it opposes EU constraints on collective bargaining in the States, does not support commercial criteria in research and demands the EURATOM Treaty be repealed, with a total abandonment of nuclear energy to avoid the complete failure of environmental policies.

For the DL neoliberal policies must be ended, not an impossibility as the triumphs [though ephemeral] of the referendums in France and Holland in 2005 and Ireland in 2008 have proven. The alternative proposal is to establish control of multinational corporations and international financial centres, with strict regulation of capital flows and their transactions in order to prevent speculative manipulation. The Stability Pact should be replaced with another promoting sustainable development and full employment and also there will have to be an increase in the insufficient EU budget and redirect this for social issues: "Die Linke advocates the prioritising of political and social rights above the free market". To do this, "Europe needs a European government, oriented to employment, social cohesion and the sustainable economy". The recovery and strengthening of the European social model should serve to give way to "a new economic and financial order", countering speculation. In summary, the DL calls for "a Europe of people and not of business" in which social rights are not mere commodities. Finally, it is in favour of some further enlargement - but with a strategy of solidarity - and the rescue of CEECs after the "brutal" adjustments of their economies and societies.

- The FG argues that "this crisis is also the failure of "liberal Europe", an expression of the "historic crisis of capitalism" (a term, incidentally, which is already more than a century old). According to this party, "the EU is fully committed to the bankrupt neoliberal capitalist model". From this perspective, the entire EU policy is aimed at privatisation, deregulation and the concentration of resources for the few. In summary, we should "question the dogma of free trade, develop public services, democratise them and reject their liberalisation" and all available instruments in the EU should be at the priority disposal of social and environmental interests.

- SYRIZA rejects the "pacted liberal-conservative/social democratic" EU - two sides of the same neoliberal coin that continues to cut social rights. Since the Treaty of Maastricht the expansion of neoliberal has not ceased because, on one hand, public money is used to rescue ailing banks and on the other social rights are cut. Neoliberalism severs national sovereignty and community institutions only "reinforce the measures that increase capital profit". This coalition opposes further 
privatisation, public spending cuts and policies designed to help development at the service of multinationals. For SYRIZA the "preservation and expansion of the welfare state" must be undertaken, clearly explaining to the public that it is the neoliberal capitalist order and an EU at its service that has caused the current crisis, hence the "need to show an alternative route to call into question the neoliberal hegemony and the capitalist system". At the end of its manifesto, the slogan of a socialist Europe led by the left as the only long-term solution is reaffirmed.

- According to the VP, "the free market is superior to everything, more important than the environment, social rights and consumer protection". That is, in the EU, the rights of companies are much more important than anything else, proving that "peace, prosperity and solidarity have never been [its] priorities". In specific policies, the VP is against the current CAP that only benefits large agribusiness and livestock producers, and demands the re-nationalisation of the sector. It rejects the commercial criteria of the EU's external trade policy, even more neoliberal and even neocolonial than that of the U.S. and it opposes the fact of Brussels deciding environmental standards and restricting state policies in these areas. Much in keeping with the high standards demanded by Scandinavian ecology, the VP asserts: "The EU is a bad scenario for climate and environmental policies" as they are subordinated to corporate interests. The VP "works for equality and against discrimination and repression $[\mathrm{sic}]$ in the EU", does not accept that the EU can "interfere in welfare policies of member countries" (this is a widespread concern in Scandinavia) and claims to be a party "representative of many voters who oppose and are critical of the EU".

\section{Table 4}

The economic policies of the EU increase social inequalities

The economic policies of the EU only benefit an oligarchy

Essential public goods should not be privatized

The alternative is to recover the welfare state

The alternative is to leave the EU and reclaim socialism

\author{
All \\ $\mathrm{BE}$ \\ KKE \\ CDU-PCP \\ DL \\ SYRIZA \\ VP \\ All \\ SF \\ AKEL \\ KSČM \\ $\mathrm{BE}$ \\ IU \\ DL \\ SYRIZA
}

KKE 


\section{The democratic deficit and national sovereignty}

\subsection{The limits of European democracy}

The SF rejects the Lisbon Treaty for being undemocratic and ruinous for Ireland, i.e., for not reflecting - in its opinion - popular interests and not really making Community institutions controllable. This was the text rejected in 2008 by the Irish South (Republic of Ireland) and deprived the people of Northern Ireland the opportunity to voice their opinion. The SF criticises an unelected and unaccountable Commission and a Court that prioritises the free market and private profit over sustainable development and a fair redistribution of wealth. In addition, the EU increasingly meddles in tax matters, something that should be immediately stopped at the root as this affects Irish tax sovereignty. The SF then proposes a thorough restructuring of relations with EU institutions through new and truly democratic treaties that should always include the Social Progress Clause and to strengthen the role of national and regional parliaments to correct the serious democratic deficit in the Community. Additionally the noticeably weak civic participation in decision-making in the EU should be increased and its finances made more transparent.

- The AKEL asserts that the failure of the TCUE "shows the wide gap between the aspirations of the peoples in the EU Member States, the governing circles in Brussels and the ruling classes in European states". From the institutional point of view, the party is in favour of increasing the powers of the EP as the main way to improve the poor quality of democracy in the EU.

- The Czech Communists criticise the fact that in some countries the EU now have an exorbitant weight in decision-making processes, apart from the four principal community freedoms "they do not ensure a decent life for citizens - not even offering protection against the economic crisis. The influence of the market is implacable". This has projection in the community's political model - for the KSČM dominated by an uncontrollable bureaucracy taking decisions with enormous lack of transparency and imposing many meaningless rules.

- The fact that the TCUE and the Lisbon Treaty have been rejected by three European nations and, despite this, the Lisbon text is in force, for the $\mathrm{BE}$ this is damning evidence of the unsurpassed elitist and undemocratic nature of the EU. It reveals the democratic deficit of the EU that acts with arrogance and authoritarianism to the exclusion of citizens. The BE demands a move beyond the anachronistic Lisbon Treaty and the drafting of a new text, a task that should be left to Parliament. A new treaty, concise and precise on objectives, rights and 
institutions that should be subject to national parliaments. Also, the $\mathrm{BE}$ demands the democratisation of the European Central Bank, whose primary objective should be to place monetary policy at the service of job creation, which would require the establishment of mechanisms of social solidarity and equitable economic coordination in the EU. In summary, the BE states: "We are Europeans, but we are not eurocentric. We are pro-European, but we are not Eurocrats".

- The KKE maintains the same argument as the BE for the people of France, Holland and Ireland to indicate the path they should follow in the current EU. The Greek Communists, even more emphatically, disqualify the EU Treaties as "reactionary" for being so negative for workers and society.

- In accordance with the unique interpretation of the Portuguese communists, the EU is based on inseparable triad (neoliberalismfederalism-militarism) whose logic is profoundly undemocratic and antisocial: the Treaty of Lisbon "heightens federalism as form of concentration of economic and political power in the large scale European capital and major powers". Each step in the deepening of federalist institutional integration leads to the strengthening of the other two pillars, neoliberalism and militarism. Therefore, the CDU-PCP calls for a "combat against illusions based on federalist visions of Europe". Consequently, their institutional proposals are clearly statist and intergovernmental: the Council of Ministers (today, the Union's) is the entity that should have a leading role in the EU, ensuring each country has a vote and the right to veto. The CDU-PCP demands the maintenance of one commissioner per country, does not admit the reduction in the number of MEPs that can affect smaller countries like Portugal and rejects the transfer of justice and interior affairs to the community level, as this subtracts "competencies from the sovereignty of States'.

- The IU states that the "Lisbon Treaty demonstrates the political absurdity of where the Union now stands" a text obsessed with setting "free market pre-eminence over any other issue". For this group, the popular rejection expressed in some referendums show some civic disagreement with so many anti-democratic and anti-social EU policies. The IU considers that European institutions have been at the exclusive service of dogmatic neoliberal policies. To reverse this course, "the EU should be open to the democratic participation of the entire society because if not, there is no future for it". The democratisation of the EU involves giving way to responsible governance, the full guarantee of human rights, respect for minorities and the full participation of civil society with a capacity for control. On one hand, the IU states that the EP has to be enhanced ("it must have power to initiate legislation") and 
on the other, defends "a truly European constitutional process". A new draft Constitution for Europe could only emanate from a democratically elected Constituent Assembly by direct universal suffrage for all citizens of the Member States and with a mandate to do so. Then, the new Constitution should be put to a referendum in every country on the same date.

- According to the DL, the EU states are increasingly addressing international crises with the use of military force, something that the Lisbon Treaty has strengthened. This is one of the main reasons for this party to oppose the same, using this to compete effectively with the Greens in Germany, historically the champions of pacifism which, incidentally, they have modulated after their experiences in federal government. The DL programme is quite detailed when criticising the democratic shortcomings of the EU Treaties and makes various alternative proposals: the President and all the Commission must be elected by Parliament, it must have the same political weight as the Council, the jurisprudence of the Court of Justice should not focus on the dogma of free competition because this limits the rights of workers, $50 \%$ "of all positions in the process of decision making at every level of the European institutions" must correspond to women candidates (this is also competitive with the Greens), Europol should not be "an agency of the European Union" and, finally, the storage of personal data that the EU is carrying out under the pretext of fighting terrorism is not admissible (the Treaty of Prüm, the agreement of 2007 with the U.S. on passenger data for flights) as this limits guarantees on individual rights. Instead, the EU should create a European tax for corporate and financial profits, at the same time simultaneously fighting against tax havens in a much more effective way.

For the DL democracy must take precedence over market radicalism and for this it needs, on one hand, to give way to a European economic government rather than the economy governing Europe, and on the other, approve a truly democratic European Constitution "the EU needs another contractual basis: a Constitution for the EU designed by citizens and endorsed by them in each of the Member States". To this end, the DL advocates that the EP assumes the task of promoting the only institution to be legitimated by citizens and then ultimately gives the final word to them via referendum. Among the items that such a text should contain, the DL indicates a true separation of powers, economic neutrality (the European Constitution should be open to a mixed economic order in which the public sector can be the more relevant) and a vocation for the peaceful resolution of conflicts, implying progressive disarmament. To move in this direction, the DL suggests combining both the institutional struggle, as well as grassroots movements, very 
much in line with some features of its political culture so critical of the system: "the democratisation of institutions and the democratisation of the economy can not be achieved without the extra-parliamentary organisation of a countervailing power. For this reason, we want to support a European network of networks".

- The FG asserts that the EU suffers from a serious democratic deficit, with many unelected powers and not subject to the principle of popular sovereignty. This group rejects the Lisbon Treaty on which the French people have not been able to voice an opinion, which invalidates the referendum on the TCUE whenever the new text is basically the one rejected. The only institutional reference in its election manifesto is to the European Central Bank, an entity subject to the financial markets which should be placed at the service of society and subject to democratic control. The FG demands an independent Europe that rejects the competitive logic between peoples and pursues policies of peace and just cooperation.

- SYRIZA fully supports the rejection of the TCUE in France and Holland in 2005 and the Treaty of Lisbon in Ireland in 2008, expressions of popular opposition to hegemonic neoliberalism. This coalition demands the repeal of the Lisbon Treaty and the calling of obligatory referendums for successive texts. In its opinion, EU institutions are constantly slimming democracy and popular control over governments and this is what requires a profound institutional change. The EP should always be informed before and after the meetings of the two councils, national parliaments should increase their auditing capacity, the Court of Justice would require a major overhaul since it continues to cut social rights on an ongoing basis and the Central Bank currently an uncontrolled neoliberal fundamentalist entity - should be changed from the roots up.

- The VP claims that supranationalism and the community Treaties in force respond to unacceptable policies as "the Lisbon Treaty transfers extensive power to the EU system controlled by the elite and the bureaucracy", leading it to demand a referendum on this text in Sweden. This party asserts that "the EU is not democratic" nor transparent, nor fair, nor that the growing alienation of citizens is a coincidence. In its view, EU legislation is increasingly uncontrollable, secretive and invasive and therefore "we vote against proposals to increase the power of the EU". It is an entity in which it is impossible to demand real responsibilities from decision makers who only act "in favour of their own interests". The EP is conditioned and limited by projects that can only be submitted by a bureaucratic Commission serving interest groups linked to big business. The most shocking is that once this lack is 
illustrated, the VP, instead of advocating an increase in the powers of the EP, affirms that it "must be replaced by a gathering of members from national parliaments". This idea - effectively nationalist contradicts the entire historical strategy of the bulk of left wing proEuropeans and, translated, would be a regression to the situation before 1979, the year of the first direct elections to the EP. With respect to the Court of Justice, the VP criticises the fact that democratic decisions of the EP can be overridden (thereby ignoring its partial role as an effective Constitutional Court) or the non-approval of state decisions favourable to social rights (without realising that community law is superior to that of the national entity in their areas). Consequently, the party demands that "control of the police and justice should be taken from the EU". At the same time, it criticises the lack of financial transparency in the Community which increases fraud and embezzlement and threatens to extend its fiscal competencies. For the VP, "the EU must decide on taxes" and criticises Swedish parties of the establishment because, although the Swedish people rejected the Euro in a referendum (2003), those - who are pro-Euro - adapt national economic policies to the same. For the VP, democracy over community governance must be a priority, social justice over market freedom, peace over defence.

\subsection{National sovereignty and popular interests}

- For the SF the national interests of Ireland are a priority in Europe, its view includes the whole of Ireland and from there it seeks community support for the reunification of the same. This party argues that the strategic plans of the EU should take into consideration the reality of a global "whole Ireland" when nominating objectives for EU funds because the "structural distortions" caused by partition must be compensated. In its view, the reunification of Germany in the EU indicates the path Ireland should follow regarding this. The SF defends strong economic sovereignty for Ireland, with strict control over natural resources and strong regulatory mechanisms for the market and the Treasury. In addition, it demands the support of Gaelic in EU institutions. The SF is against the CFSP/EPSD as they subordinate national interests and these policies are increasingly linked to NATO, which affects the neutrality of the Republic of Ireland. Finally, the party rejects ceding national sovereignty in police and judicial matters to an insufficiently democratic EU, which is also unacceptably restricting the right of asylum. The SF argues that Europe is becoming a security fortress, "this is the main reason why we oppose greater integration and centralisation of police and judicial powers" and that "we do not support the Schengen system". 
- From the outset, AKEL states its priority in the EP to be the fight for the rights of the Cypriot people, which is why this party demands more EU pressure on Turkey to resolve the problem of the division of the island. In its view, the Turkish Cypriots should not be able to vote in European elections in the present circumstances, but this does not prevent AKEL wanting to maximise closer relations with Northern compatriots. AKEL opposes the increasing militarisation of the EU and demands an autonomous European foreign and defence policy without reliance on NATO.

- The priority for the KSČM is to obtain contracts for Czech companies and reject NATO for subordinating national interests to the U.S.A., "the KSČM rejects NATO's aggressive policy that has triggered local wars on behalf of the United States (...). We reject the participation of the Czech Republic in foreign military missions in our country".

- The BE states, "we want a bigger and better Europe, but we reject the standardisation, reduction of local culture and the lack of respect for the mosaic of peoples, languages and countries that make up make Europe", a fear - in fact - entirely unfounded because not even the most radical European federalist has ever proposed (nor could even try) to standardise the immensely rich pluralism within the EU. The BE points out that the EU has no real foreign policy, what little there is, is fully subordinated to the U.S.A. Consequently, European defence does not need NATO, an organisation inherited from the "Cold War" which, - in the opinion of this party - should be dissolved. In matters of cooperation with dependent countries, the behaviour of the EU is "deplorable" because its migration policies are increasingly restrictive and repressive, violating the fundamental right of the free movement of people.

- On one hand, the KKE claims that European funds for Greece have been established under very harsh and negative conditions for the country as they benefit the capitalists much more then the people and on the other, states that Greece alone has sufficient resources to ensure a wealth redistribution far superior to the actual situation. The KKE completely rejects the PESC/PESD and the eventual configuration of an improbable European Army and demands the withdrawal of Greek troops on NATO/EU missions. In its view, interventionism of the EU on humanitarian pretexts or the fight against terrorism are the equivalent to assuming the doctrine of preventive war led by the U.S.

- For the CDU-PCP the Lisbon Treaty violates the Portuguese Constitution whenever Portuguese law must be sovereign (ignoring the normative hierarchy of the sources of law with reference to Community supremacy, as the Court established decades ago). In addition the 
treaties should be reversible and should prevent further transfer of sovereign powers to the EU because they subordinate Portugal. The CDU-PCP affirms that EU policies are at the service of the major powers in the EU (not only the usual triad - Germany/France/UK, but also Italy and Spain, (the latter being criticised - highly characteristic of Portuguese nationalism) and this affects the capacity of small countries such as Portugal, removing its control of national resources, both materially and even spiritually. In the latter sense, the CDU-PCP demands "the respect and the uncompromising safeguard of the cultural identity of each country and of all official and working languages".

It is noteworthy, in particular, the anti-federalist obsession that responds to both Portuguese Communist nationalism and to a prejudice because the alleged political federalisation of Europe has not been empirically verified. The CDU-PCP defends a "Europe of cooperation between sovereign and equal states", with "full respect for national sovereignty" against supranational impositions and federalism. In this sense, like the KKE with regard to SYRIZA, in Portugal the CDU-PCP has to face a competitive rival in the electorate of the radical left - the $\mathrm{BE}$, leading in turn to forceful criticism of same "the Leftist Block essentially shares the federalist philosophy that proposes a strengthening of the supranational character of the EU's institutional framework, devaluing and belittling the central importance of preserving national sovereignty as a guarantor of democracy". For the CDU-PCP the EU is rapidly militarising in serving the interests of U.S. and also, is configuring a "fortress Europe" with a discriminatory immigration policy.

- The IU rejects the "rearmament the Lisbon Treaty advocates" and the subordination of the EU to the U.S. Consequently, the party calls for the dissolution of NATO and is against the creation of European military structures, although it affirms - somewhat contradictorily - that the EU should have its own form of "security" detached from the NATO and the U.S. In summary, for the IU NATO is a serious threat to European sovereignty and U.S. bases on European soil should disappear. As a party favourable to EU enlargement and, in particular, Turkey's candidacy, the IU makes only one remark with regard to this: "the prerequisite for Turkey's entry into the EU is the withdrawal of this country of Cyprus".

In Spain, a country with a recent massive reception of immigrants, the IU criticises the contradictory policies of the EU in this area. In its view, EU policies have centered on external border controls with an "extremely hard sanctions system" of "irregular migrants". On the one hand, "the EU has chosen to fortify" and on the other, "the absence of a 
genuine European immigration policy has been supplemented by repressive measures". In summary, the IU affirms, "we want to work towards a cosmopolitan Europe - open to immigration".

- From a decidedly non-nationalist perspective, the basis of the DLs political thought in the dimension related to sovereignty has a clear antimilitarist commitment exceeding the German Greens. For the DL, security in Europe must be based on disarmament, non-intervention and the peaceful resolution of conflicts within the framework of the OESC and the UN. Moreover, in the opinion of this party - the EU has set a disastrous precedent in Kosovo, having violated international law (this being true, it can not be ignored that the bulk of this party historically originates from the old SED and with the Yugoslav conflict always showed "understanding" of the Serbian authorities' viewpoint, proceeding as they did from the former Titoist nomenclature). The DL argues that the FPCS/EPSD encourages militarism and rejects enlargements of NATO and the overseas military missions. The party advocates the dissolution of NATO and the forces of EU military intervention "the cooperation and links between NATO and the EU have to end". Its ideology is so doctrinally hyperpacifist that the "DL opposes all war missions, even those with a UN mandate" and that because "Humanitarian' military interventions" do not exist. Being in favour of the enlargement of the EU, in the case of Turkey the DL states that this country "must respect and ensure the human and political rights of all its people, including its minorities." On community policies for specific States the position of the DL is very orthodox: the EU should withdraw its unconditional support for Israel, to renounce its confrontation with Iran and "normalise" relations with Cuba.

On the issue of immigration, the DL demands the abolition of the border protection agency Frontex because it is "opposed to the current policy on immigration and asylum in the EU". Also, the detention camps for illegal immigrants must be abolished because the immigration law can not be subordinated to the interests of the economy to provide cheap labour. The DL wants the recognition of full rights for the approximately eight million "undocumented" people residing in the EU and opposes the "return directive".

- On a similar line, though not as developed, is the criterion of the FG for whom the EU should not be linked to the militaristic policy of the U.S.A: "Europe must break its Atlanticism and its alignment with the U.S., especially in the framework of NATO". On the issue of migration, the FG demands the extension and strengthening of the rights of immigrants and the repeal of the "shameful" return directive. 
- SYRIZA disagrees with creating a European superstate without the support of the people and without transparency. This coalition is not against cooperation between European peoples, but "the major field of conflict remains in the national States" and it is there where we have to change the balance of power to modify the character of the current unification of Europe. For SYRIZA a worrying attempt to create a European army is under way, which would increase the future risk of aggressive interventionism. So this group is opposed to what it sees as a drift towards militarisation in Europe and because of this demands the abandonment of Greece from NATO due to its imperialist policies. On Immigration - it is against both cutting the social rights of immigrants and not legalising undocumented migrants.

- According to the VP, with the Lisbon Treaty, the EU has taken "a major step on the road to a super-state" with increasingly intrusive ambitions and it "does not accept the dictates of EU bureaucracy as the interests of voters are more important than the establishment of the EU". For the VP as "there is no strong public support to build a European super-State" the continued strengthening of the EU "must be avoided". This does not prevent the maintenance of fair, flexible and free cooperative formulas between States and peoples, an impossibility from its point of view - with the current elitist and bureaucratic EU. The deep distrust the VP has for the EU has a nationalist substrate linked to the protection of the welfare state itself: this is not the EU of 1994 when Sweden joined and today the large countries prejudice the smaller countries. So, on one hand, "the Swedish collective model is challenged by the EU system", and on the other, "Sweden's membership of the EU has had negative effects for work and public welfare". Not surprisingly, then, the conclusion: "We want Sweden to leave the EU".

The EU is already - as it is - effectively a military Alliance, with active "preventive" strategy policies that all contravene Swedish neutrality: [the VP] "will continue their struggle against the militarisation of the EU (...). The EU should not be a military defence alliance and Sweden should not participate in a progressive adaptation to NATO". The VP points out that Sweden has its own defence system and if it participates in an international operation this should only be possible - in its case - with UN and of course Swedish Parliamentary authorisation.

The VP opposes a "Fortress Europe" that clearly discriminates and restricts rights. The party is opposed to the expansion of Community powers in the areas of police and justice because the use made of the same proves the fact of the growth of hostility in the EU towards non- 
EU peoples. Finally, the VP is a strong supporter of strengthening the right of asylum and the free reception of immigrants.

\section{Table 5}

$\begin{array}{ll}\text { No o the Treaty of Lisbon } & \text { All } \\ \text { Strengthen Parliament } & \text { AKEL } \\ & \text { BE } \\ & \text { IU } \\ & \text { SY } \\ & \\ \text { Strengthen national parliaments } & \text { SF } \\ & \text { CDU-PCP } \\ & \text { VP } \\ \text { Primacy of National Sovereignty } & \text { SF } \\ & \text { AKEL } \\ & \text { KSČM } \\ & \text { KKE } \\ \text { CDU-PCP } \\ \text { No to a European federal superstate } & \text { CDU-PCP } \\ & \text { SYRIZA } \\ \text { Leave the EU } & \text { VP } \\ & \\ \text { Not to CFSP/ESDP within NATO } & \text { KKE } \\ \text { Free reception of non-EU immigrants } & \text { VP } \\ & \\ & \text { All } \\ & \text { BE } \\ & \text { IU } \\ & \text { DL } \\ & \text { FG } \\ & \text { SYRIZA }\end{array}$

\section{The balance of radical left parties}

The direct denouncement of neoliberal policies in the current EU is not only the unanimous leitmotiv of this ideological group, but also the most developed in their election manifestos. As parties that, in general, are linked to the historical tradition of the labour movement and anticapitalist socialism it is no accident that they devote about half of their programmes to criticising the existing European socio-economic model that is objectively harmful to workers. All agree that the economic policies of the current EU aggravate social inequalities, precariousness and marginalisation and several specify that these only benefit a small 
speculative financial oligarchy, unconnected from the real economy, which has subordinated governments according to their strict class interests. All the groups strongly support giving primacy to the public sector and, more particularly, the non-privatisation of essential goods and services because a society can not be considered as marketable commodity. An interesting point of interest is that, in a great majority of cases, their alternative proposals are not revolutionary in character as they limit themselves to asserting the need for the classic Welfare State of the "thirty glorious" years (1945-1975). In other words, the bulk of the radical left does not demand the opening of a path to an anticapitalist programme of a transition to socialism, but - more modestly and realistically - to take the model of a mixed economy and universal social coverage typical of the post-1945 Western Europe tradition seriously. With this, the extreme radical position of the Greek Communists is exceptional, the only group that explicitly considers that the welfare state has been superseded from a historical point of view.

In the other two areas (democracy and national sovereignty) there is a connection because - in theory - this group of parties do not consider themselves doctrinally nationalist. So, in general, the defence of national primacy vis-à-vis the EU is undertaken not with essentialist arguments about ethnicity more or less, but about democracy: the democratic inadequacies of the current EU make it inadvisable to cede new lots of national sovereignty as this would be detrimental to popular interests. In other words, in an elitist and bureaucratic EU as we have today, we would be sacrificing democracy if we continue ceding lots of national power. So, while the EU does not undergo a real process of democratisation, the defence of national sovereignty is more than anything a democratic rather than a strictly nationalist imperative, though the objective effects of this policy today strengthen civic nationalist movements in many states. All parties of the radical left reject the Lisbon Treaty, especially because a fraud has reputedly taken place against countries who rejected the CTEU (in the view of these parties the Lisbon Treaty is practically the same) or the same (in the case of Ireland). This Treaty is presented as the consecration of the starkest neoliberalism in all its dimensions and even with the most elitist and anti-democratic opacity in its institutional format.

Now, when judging the existing alternatives in the dimension of the quality of democracy, two attitudes stand out: 1) several parties, in accordance with the historical tradition that is in principle more favourable to the supranationalism than that the internationalist left has defended, are particularly in favour of increasing the powers of the EP more than anything, yet 2) others, however, are wary of this approach and require the strengthening of the power of control and even the veto 
of national parliaments, making them stronger than the EP. The first group is almost entirely made up of postcommunist or recycled communist parties, while in the second there is more heterogeneity for various internal reasons (they take nationalist positions here, for different reasons - three parties that are very different from each other: the SF, with an irredentist character, CDU-PCP, orthodox, and the VP, which is postcommunist).

The emphasis on national sovereignty as a shield against EU intrusions is very characteristic of the classic communists, the most enthusiastic supporters of this old doctrinal principle of little relevance in the world today. Not many clarify what their political project for the "other" Europe would be, or those who explicitly reject its eventual federalisation, the option with which both Communist and postcommunist parties coincide, so national conditions being once again those that determine the strategy of each party in this area. The option of leaving the EU is also a very exceptional, radical proposal - only two parties, one Orthodox and the other postcommunist, have come postulate this.

The rejection of the EU's current CFSP/ESDP is unanimous as the overall criticism is that they serve the interests of NATO and, worse, the U.S. For the majority of these parties the security and defence policies of the EU are taking on a dangerous militaristic drift that does not even benefit European states as such as they are in line with Washington's agenda. With the rejection of NATO being virtually unanimous, it is also significant to find that several of the radical left parties - though they are a minority - refuse even to consider the possibility of creating a distinct European defence system, detached from NATO and the U.S. The anti-militarist and anti-imperialist culture so characteristic of this ideological group has produced a deep distrust and even rejection of such an option.

Finally, the issue of immigration is only mentioned by the parties from the countries where it is a relevant issue in the political agenda (Germany, France and Spain, in particular). They all have a very receptive attitude to non-EU immigration that they regard as a key contribution to European development. Their policies are flatly contrary to restrictions or repressive hardening of immigration laws - on the contrary, they are in favour of unfettered, free reception, hence their complaints of the current Community involution regarding this issue. 



\section{Conclusions}

From the outset, the main problem of the term Euroscepticism is its conceptual vagueness by including not exactly matching semantic meanings (rejection/reservations). In this regard, it is useful to distinguish not only between respective positions, but also clarify the scope and meaning of these reservations: in short, outright rejection implies Europhobia, reservations (especially political) imply Euroscepticism in the strict sense and dissatisfaction with the current impasse of the actual EU that eurocritical postures embody. Following this through to its logical consequence, the theoretical possibility even exists to dispense with the term of Euroscepticism, although this process may already be irreversible due not only to its full academic acceptance, but also to the progressive conceptual purification and the rich empirical research that has been developed.

Euroscepticism is and is not a new cleavage and although European policy has traditionally had a secondary character in national States, it will become increasingly less so since many of the internal problems are interconnected with those derived from the contradictions of the actual process of integration and this is what increases politically relevant social and partisan divisions within the same. It can be said in conclusion that there is Euroscepticism both for economic reasons and for political and cultural reasons. More precisely, they are the negative evaluations in terms of cost/benefit, the rejection of the elitist and delegative style in community institutions (notoriously opaque) and a fear of losing "identity" the root causes of the phenomenon. Something that has gained widespread projection almost all the EU States and is manifested both in parties and with voters across the ideological spectrum, with different intensities depending on the country and situation.

Indeed, some parties channel such perceptions and civic feelings, while not quite matching the critical positions and policies of the parties of the radical right or left because with the former Euroscepticism is not just a waymarker, but also a principle (although most pragmatically accept carrying on in the EU), while in the latter the fundamental discrepancy is with the path itself (sharing neither the style nor the policies of the Community authorities) as there are very few who reject the principle of integration. Although it is a controversial issue, it appears that - despite obvious ideological differences - there are a few 
items critical of the EU that the radical right and left share, though the emphasis on one or the other differs. To begin with, there are sectors of the electorate of these parties that may not only overlap, but may also even be interchangeable (roughly, the "losers" of the current process of European integration). Then the social discontent of significant sectors against "central block" parties and governments and against representative institutions increasingly perceived as distant, can be captured almost indistinctly by ideological parties of either ideological group. Although the radical left and right can agree on the defence of national sovereignty, they undertake this with distinct ideological criteria: ethnicity in the first instance and the defence of national sovereignty in the second. In this area there is a major antagonism between respective ideological groups with issues related to non-EU immigration and the Turkish candidacy: the radical right declares itself xenophobic while the radical left openly manifests a desire for integration. Similarly, the extent of the criticism of neoliberal politics is different - in the case of the radical right it is rather circumstantial and secondary, while for the radical left it is part of the core of their policies. Finally, regarding the "democratic deficit" of the EU itself there is a notable coincidence regarding the opacity and elitism of "Brussels", albeit with a much more populist tone from the right than from the left.

Some analysts have hypothesised various future scenarios regarding Euroscepticism, well synthesized by Leconte: 1) marginalisation (despite the difficulties, the process of European integration is unstoppable and ongoing), 2) reinforcement (in fact, significant establishment parties have a growing Eurosceptic presence in their ranks) and 3) reforming reorientation (in this case, Eurosceptics assume that a certain kind of EU is irreversible, but with a "defederalising" reorientation from within). Given these scenarios, there could also be three responses: 1) maintain the status quo (not embark on any new projects of ambitious reform to avoid risk), 2) radically re-shape the EU (i.e. give way to a genuine political federation, something not feasible today given the correlation of forces) and 3) reform the EU incrementally (continue with a functionalist strategy of the lowest common denominator, the only way - with all its limitations - that allows partial progressive progress).

When classifying the variants of Euroscepticism it is relevant to recall the observation of Sczerbiak and Taggart on the inconvenience of multiplying the theoretical categories due to the difficulties in making them operative. Consequently, this study concludes with a proposal for a personal adaptation of the more nuanced model from Kopecky and Mudde based on four positions: 1) Europhiles, 2) Europragmatics, 3) Eurocritics and 4) Europhobes. The first group shares the principle of integration and the direction in which the current EU is moving, the 
second group does not accept the principle, but accepts the results, the third group is the most integrationist, but rejects the current process and the fourth group rejects everything.

Table 1

\begin{tabular}{|l|c|c|}
\hline & Principle & Direction \\
\hline Europhile & YES & YES \\
\hline Europragmatics & NO & YES \\
\hline Eurocritics & YES & NO \\
\hline Europhobes & NO & NO \\
\hline
\end{tabular}

Source: the author.

In any case, the term Euroscepticism is already well consolidated academically and the proposal put forward is merely a theoretical suggestion that needs to be proved with empirical tests. In this sense, this scheme can adapt to the term eurosceptical with the distinction of two subcategories of the same: not hard and soft, but those affecting "mixed" positions. In other words, the contrast between Europhiles (double yes) and Europhobes (double no), seems very clear, the position of Eurocritics and Europragmatics being more ambiguous. Both categories can be defined as eurosceptical, but in different ways: the Europragmatics being negative Eurosceptics and positive Eurocritics the positive Eurosceptics. This is: the negative Eurosceptics can accept a EU of simple intergovernmental economic cooperation, while the positive Eurosceptics believe that with the current direction the economic and statist limits will never be exceeded, its own supranational project being much more ambitious. With this, the resulting picture allows a reasonably systematic grouping of the main party groups: 1) Europhiles (parties of the "core block"), 2) negative Eurosceptics (conservative, agrarian), 3) positive Eurosceptics (radical left) and 4) Europhobes (radical right). Of course, this picture is merely indicative and not only supports various exceptions, but also any new partitions - in principle the bulk of the party options can fit into this area.

As a balance of affinities and differences it should be noted that there is more Europhobia on the radical right than on the radical left. This is significant because of the level of the former's rejection of integration, something quite unusual with the latter. The objective coincidence between both is produced in the way they respond to the operational channels and methods of the present EU, albeit from different ideological perspectives. Both criticise the Community establishment who they feel are distant and do not generally count on them.

Consequently, the EU is perceived as an artificial web and distant, damaging to national and popular interests. This explains why the 
radical right and left collect much of the discontent and protest from many of the citizens affected by the ongoing integration process.

From the outset, the principal distinctive argument the radical right has in its criticism of the EU focuses on the emphasis on national sovereignty, severely endangered - in its opinion - by "Eurocrats". It should be noted that, while not being the primary objection of the radical left, a large part of it is sensitive to this reasoning and also opposes the transfer of new lots of national sovereignty. However, the main difference between them is the focus given to this classic concept: a focus on ethnic exclusion in the first case and the condemnation of the limitations of democracy in the second. Just as the radical right so unanimously rejects the hypothesis (from its perspective, a reality in the making) of the European superstate, the radical left (with exceptions) may not oppose this scenario, but only with very specific conditions (with another political and economic model). In short, the radical right, looking through its nativist nationalist prism, does not accept the supranational progression of the EU, nor the continuing expansion of the same. In contrast, the radical left's principal distinctive feature of its opposition to the current EU lies in its rejection of neoliberalism, notoriously harmful to social rights. Part of the radical right is not insensitive to this argument and does not accept the current supranational economic model of the EU as it stands, serving only the interests of opaque transnational lobbies. This ideological group advocates a protected domestic market and a welfare chauvinism reserved for national citizens, elements that the radical left do not share. Finally, it criticises the democratic deficit of the EU's institutional framework, reinforcing its belief that without a total change of system it can not be supported; a criterion the radical right partly shares in considering that the Community authorities are accountable to nobody.

\section{Table 2: Predominant Items in the discourse of opposition to the EU of the radical right and left wing (high to low)}

Right

1) Yes to national closed sovereignty
2) Yes to ethnic identity
3) No to European federal superstate

Source: the author.
Left

1) No to neoliberalism

2) No to democratic deficit

3) Yes to national sovereignty linked to popular interests

For its part, the European Parliament elections of 2009 reiterated the "secondary" character of this call to elections and the constant civic disinterest towards them. The overall result has strengthened the centerright as a whole and has also consolidated the radical right to a degree. 
In turn, the decline of center-left is notable and the maintenance (with a slight downward trend) of the radical left. Therefore, despite a certain superficial impression that these elections have mainly benefited the more radical groups, the results show a more nuanced picture, a certain "freezing" of the inherited situation. In any case, the radical right has endemic difficulties to structure itself into a single parliamentary Eurogroup - however, the radical left demonstrates the greater predisposition to integrate into a common entity (despite the not insignificant internal differences).

The treatment the analysed parties' electoral manifestos give to the three chosen dimensions is very unequal - those of the radical right favour the stubborn defence of national sovereignty in its criticism of the EU while those of the radical left focus on denouncing neoliberal socio-economic policies.

Instead, a similar space is given to "democratic deficit" and therefore it is necessary to initiate a conclusive analysis from this dimension - and not only for quantitative reasons, but also because the question of democracy in the EU is qualitatively connected to the other two because it directly conditions them. The deficiencies attributed to community institutions and procedures are the ones which are projected negatively on the national interest and the social rights of the population. So, with different priorities and strategies in this triad, the radical parties of the right and left present various objective coincidences in their criticism of the EU, but with some evident, profound differences that separate both ideological groups (the issue of immigration, in particular).

The "democratic deficit" denounced by everyone crystallises in the almost unanimous rejection of the Lisbon Treaty. The critics then agree: this treaty enshrines the elitist and bureaucratic EU for reasons of both form and substance. From the first point of view, it has violated the right of citizens to voice a direct opinion and from the other, the Lisbon Treaty only preserves the opacity in the operational and decisionmaking processes of Community institutions. It is not unusual to detect a significant distrust of representative mechanisms in both ideological groups, albeit with a greater emphasis of this in the case of the radical right. These parties all demand - with a populist character - to "give voice" to the citizens to express their views on any reform of the Treaties, being precisely they who accept or reject further transfers of sovereignty to "Brussels". In addition, the current institutional framework of the EU is totally dysfunctional, disallowing a real popular control and strengthening an unchecked "bureaucracy". It should be noted that this criticism is much more characteristic of the manifestos of 
the radical left, more inclined (due to its traditional political culture) to defend the expansion of popular participation.

\section{Table 3}

\begin{tabular}{|c|c|c|}
\hline The Lisbon Treaty: & Right & Left \\
\hline $\begin{array}{l}\text { Imposes decisions not voted for } \\
\text { by each national population }\end{array}$ & $\begin{array}{l}\text { UKIP } \\
\text { LN } \\
\text { NSA } \\
\text { PRM } \\
\text { FN } \\
\text { PVV }\end{array}$ & $\begin{array}{l}\text { KKE } \\
\text { CDU-PCP } \\
\text { VP }\end{array}$ \\
\hline $\begin{array}{l}\text { Has not been submitted to popular } \\
\text { referendum }\end{array}$ & $\begin{array}{l}\text { VB } \\
\text { DF } \\
\text { FPÖ } \\
\text { FN }\end{array}$ & $\begin{array}{l}\text { SF } \\
\text { BE } \\
\text { KKE } \\
\text { FG } \\
\text { SYRZIA }\end{array}$ \\
\hline $\begin{array}{l}\text { Does not respect the division of } \\
\text { powers and cedes power to a } \\
\text { bureaucratic oligarchy }\end{array}$ & $\begin{array}{l}\text { JMM } \\
\text { DF }\end{array}$ & $\begin{array}{l}\text { SF } \\
\text { AKEL } \\
\text { KSČM } \\
\text { BE } \\
\text { IU } \\
\text { DL } \\
\text { FG } \\
\text { SYRZIA } \\
\text { VP }\end{array}$ \\
\hline
\end{tabular}

As a block all parties of the radical right pronounce themselves in defence of the absolute primacy of national sovereignty, while with the radical left this is an issue that is only defended by some. To this first difference two other orders of consideration should be added: 1) the radical right makes an "essentialist" defence of the mythical principle of national sovereignty because, very often, this thesis has ethnic and xenophobic connotations in its discourse, 2) the radical left parties that defend this issue as a priority assert that they do so in the name of the material interests of the real population, i.e. the citizens, not of abstract doctrinal concepts. A very obvious difference is the assumption of "Christian roots" as an unequivocal identifying characteristic of European peoples that some parties of the radical right make, something entirely absent in the other ideological group given their militant secularism. In any case, the myth of national sovereignty has a very clear result: the massive rejection of the radical right of an eventual European federal state, a hypothesis that some radical left parties also reject. it is not surprising then that this criterion exists in a party like the irredentist SF or the orthodox Communists who have become the main 
supporters of this classical notion (Czechs, Greeks, Portuguese). In nationalist parties such as those of the radical right, the rejection of political supranationalism is entirely congruent, but it is more difficult to justify on the left, given its internationalist tradition. The truth is that some radical left parties have effectively assumed a nationalist philosophy that they want to be progressive - disconnected from old ideological dogmas, but to preserve the material interests of their peoples in the face of an insufficiently democratic and neoliberal EU. The total rejection of political federalisation of the radical right and substantial rejection on some of the radical left, does not prevent either ideological group from accepting elements of intergovernmental European cooperation that are mutually beneficial for their peoples. However, the principal differentiating element between the radical right and left on questions related to the national community is seen with issues such as immigration or Turkey, which continue to be related. These differences are, in fact, antagonistic: for the radical right European civilization faces a deadly threat represented by an alleged "invasion" of non-EU immigrants, the vast majority Muslims. Indeed, Islamophobia and the xenophobic rejection of immigrants have become the main demagogic tools for the electoral growth of this type of party. In many cases, anti-immigrantion policies are almost the only reason for these parties to exist because they have become the resource providing more electoral dividends. In parallel, the direct and hostile opposition to Turkey's candidacy is associated with this exclusive mentality: this country has no place in Europe, its incorporation would be unnatural, it would be a huge risk for collective security - with a deterioration of social services and an increase in crime and even terrorist threats. Apart from the apocalyptic, reactionary and unfounded ideological character of these prejudices, this is a complete contrast with the positions of the radical left. Indeed, it is in favour of the continued unrestricted reception of immigrants whose rights must be recognised, both for reasons of solidarity and even as a benefit to Europeans. It goes without saying, no party of this ideological group objects to Turkey's candidacy - the only proviso being that it should comply with the requirements of the Copenhagen Accord. 
Table 4

\section{National Sovereignty}

Primacy of national sovereignty

No to a European federal state

Yes to European intergovernmental cooperation

Right

All

PVV
VB
JMM
LN
DF
FPÖ
NSA
FN

FN

VB

JMM

LN

DF

$\mathrm{FN}$

National Sovereignty

Rejection of immigration

Right
LAOS

Right
PVV
UKIP
VB
LN
DF
FPÖ
FN

Left

All

CDU-PCP

SYRZIA

VP

AKEL
KSČM
KKE
CDU-PCP

Left

SF

11

Free reception immigration

All

In principle, radical right parties doctrinally accept a market economy, since they reject the model of comprehensive socialisation regarded as Marxist. Having said this, several parties in this ideological group are against the neoliberal direction in which the current EU is going as this has negative consequences for nations and wide sectors of society. Additionally, the phenomenon of globalisation is even seen from a conspiracist viewpoint by some of them, regarding it as U.S. manoeuvre to subordinate European nations. From this stems the usual populist rejection of these groups of a greater Europeanisation of the EU as this process is interpreted as a derivation of globalisation and a subjugation of Europeans to a denationalising strategy imposed by remote centres of power. The radical right supports the market economy, but with some 
conditions: strong national protectionism to defend and preserve certain productive and commercial sectors and, more recently, greater coverage and social protection for the less favoured groups (national, of course) in each country, especially in the CEE. In any case, the fact is noteworthy that in no case the welfare state as such is defended because the radical right doctrinally attributes this model to the left and often criticises it for being "partyocratic", bureaucratic, parasitic, unsustainable and corrupt.

The radical left is against the unregulated market economy because of its serious antisocial operating methods. From this perspective, the economic policies of the current EU are discriminatory, oligarchic and undemocratic. They: 1) aggravate inequalities between a increasingly privileged minority and the majority who are having their rights cut, 2) concentrate economic and financial power in too few hands that share profits against the interests of the wider society, particularly workers, and 3) mine democracy of its meaning as representative government has fully subjugated itself to the interests of superior powers in such a way that the results of elections are irrelevant while it is impossible to change certain structural policies from the governments. The radical left parties demand a strengthening of the areas of public intervention and social welfare, hence their requests for regulations, controls, nationalisation and the maximum possible extension and the highest possible quality of universal social benefits. The most notable finding then is that these parties are the main defenders of the classic welfare state because, in fact, there are few who feel this is finished and directly defend socialism as the only possible alternative to the system (this is the quite exceptional case of the KKE). Being then the key to the welfare state what can not be ignored is that this rests on a mixed economic model the vast majority of these parties emphasise the protection of what is public against neoliberal policies because, in their view, social rights can not be regarded as commodities and must be considered as popular achievements inseparable from a modern democratic state.

\section{Table 5}

$\begin{array}{lll}\text { Neoliberalism } & \text { Right } & \text { Left } \\ \text { Rejection of neoliberal social } & \text { PVV } & \text { All } \\ \text { and economic policies } & \text { UKIP } & \\ & \text { JMM } & \\ & \text { FPÖ } & \\ & \text { NSA } & \text { PRM }\end{array}$

In conclusion, it appears that there are no Euro-enthusiasts in either ideological group, confirming that they are far from the "centre block" 
(popular, socialist, liberal) in the EP. All then, are critical of the EU, but with very different gradations, ranging from the less belligerent to the most intransigent opposers, through an intermediate majority. Effectively, both the sectorial critics that do not demand the dismantling of the current EU and those who feel the entity is lost, unrecoverable and defend abandonment and all the motley range of positions found in the parties in both ideological groups are a minority. The different attitudes must be grouped into blocks: 1) Europragmatics (minority), 2) Eurosceptics/ Eurocritics (majority) and 3) Eurorejectors/Europhobes (minority). The parties of the first block are very critical with some EU policies, but work to change the balance of forces internally and bring them closer to their respective programmed interests. There is a coincidence here from the extreme Romanians and Austrians to the left wing parties with more or less achieved ambitions for renewal and aspirations for change in the EU. The second block, which is quantitatively greater, poses a conceptual problem with reference to the label of Euroscepticism: to try to be operative this concept must be conserved by parties that, fundamentally, have a strictly instrumental attitude towards the EU, i.e., the acceptance of the same as merely an entity of economic cooperation, always from clear, inviolable intergovernmental budgets. On the other hand, there are some parties of the radical left that do not fully fit into this category because although they may share many of the criticisms of the same, they are differentiated by the fact of they advocate "more Europe" at a supranational level. Finally, the third block (a small minority), maintains the exceptional position of abandoning and even dismantling the EU, considering it to be not only useless, but even irretrievable.

\section{Table 6}

Euroenthusiasts

Eurooptimists

Europessimists
Europragmatics

$\begin{array}{lc}\text { Right } & \text { Left } \\ \text { FPÖ } & \text { AKEL } \\ \text { PRM } & \text { DL } \\ & \text { IU }\end{array}$

Eurocritics

Eurorejectors

(Europhobes)

Right Left

UKIP KKE

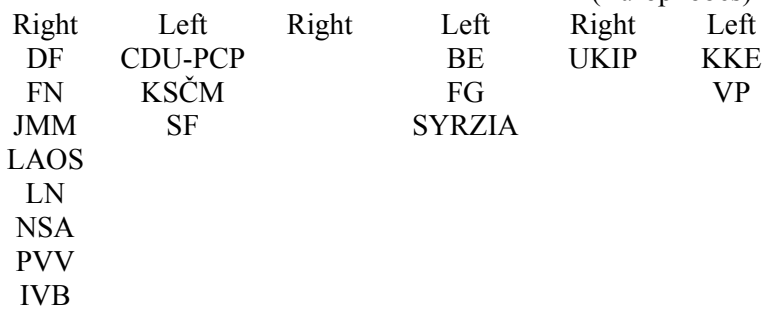

Source: self generated from the Kopecky, Mudde table, 2002. 


\section{Direct Sources}

\section{Radical Right}

DF: $\quad$ Europaiske Den Dansk Folkeparti Union-land-dit, dit valg / The EU-Danish People's Party, your country, your choice.

FN: Programme "Europe" du Front National. "Leur Notre Europe n'est pas! Voilà l'Europe that nous Voulons" / Program "Europe" from the National Front. "Its Europe is not ours! Here is the Europe we want".

FPÖ: Unser Kurs ist klar: Echte Volksvertreter EU-Verräter statt. Tag der Abrechnung 7 Juni 2009 / Our change is clear: true representatives of the people rather than traitors of the EU. Day of the surrender - 7 June 2009.

JMM: Magyarország to magyaroké! A magyar Jobbik programja to Erdek to Nemzetek Európája megteremtéséért / Hungary for Hungarians! Jobbik's programme to defend Hungarian interests with the aim of creating a Europe of Nations.

LAOS: Euroekloyes 2009 / European Elections 2009 (a).

LAOS: I Thesis tou LAOS stin Exoteriki Politiki / Positions of the LAOS regarding Foreign Policy (b).

LN: Programma Lega Nord europee 2009. Proposte obiettivi. Programmatici Punti per le elezioni Parliament 6 and 7 giugno 2009/ Northern League European Programme 2009. Proposed objectives. Points programme for the elections to the European Parliament 6 and 7 June 2009.

NSA: Program za na ATAKA Parthia Parliamentarians izbori 2009 / ATAKA Programme for parliamentary elections 2009.

PRM: Decalogul PRM. Anti-criza Program / PRM Decalogue. Programme anti-crisis.

PVV: Verkiezingsprogramma Europees Parlement 2009 / Manifesto for the 2009 European elections.

VB: Dit is ons land. Programma Vlaamse Verkiezingen 7 juni 2009 / This is our country. Flemish Election programme, 7 June 2009 (a). 
VB: Pour une Europe européenne! Ce que nous Voulons / For a European Europe! What we want (b).

UKIP: Say No to European Union on 4 June.

\section{Radical Left}

SF: $\quad$ European Election Manifesto 2009.

AKEL: Declaration of the Plenum of the Central Committee of AKEL in view of the European Elections 2009.

KSČM: Otevřený volební programa KSČM pro volvi Europského Parlamentu 2009 / Opening of the KSČM manifesto for elections to the European parliament, 2009.

BE: $\quad$ Eleitoral Compromisso do Bloco da candidacy as europeisas / Election commitment $f$ the block candidacy in the European elections.

KKE No to the EU of Injustice, Inequality, and Explotation. There is an Alternative for the peoples of Europe to follow.

CDU-PCP: $C D U$-declaração PCP program do às Eleições peias Euro2009 / CDU-PCP Programme Declaration for the European Elections 2009.

IU: Electoral programme. European elections 2009. The United Left.

DL: $\quad$ Solidarität, Demokratie, Gemeinsam für den Frieden-Wechsel in Europe! Der Partei Europawahlprogramm 2009 DIE LINKE / Solidarity, democracy, peace - Together for a change in Europe! Program European elections, 2009 the party of THE LEFT.

FG: Déclaration of princes du Front de Gauche pour changer d'Europe / Declaration of principles of the Leftist Front left for change in Europe.

SYRIZA:Politiko Plesio yia tis tou SYRIZA politikes ekloyes / The SYRIZA Draft policy framework for elections.

VP: $\quad$ Valplattform EU-parlamentsvalet / Electoral platform for the election of the EU Parliament. 


\section{Bibliography}

Alexander, R. J., Maoism in the Developed World, Praeger, Westport, 2001.

Alexander-Collier, A., Jardim X., "La nouvelle carte électorale du conservatisme européen", in Revue internationale de politique comparée, vol. 16, no. 4, 2009.

Allegri, G., "Elezioni europee 2009 in Francia: astensionismo, consenso alla maggioranza presidenziale, sconfitta socialista e nouvelle vague verde", in Caravita, B. (ed.), Le elezioni del Parlamento europeo del 2009, Jovene editore, Naples, 2009.

Backes, U., Moreau, P. (eds.), Communist and Post-Communist Parties in Europe, Vandenhoeck \& Ruprecht, Göttingen, 2008.

Balme, R., Chabanet, D., European Governance and Democracy. Power and Protest in the EU, Rowman and Litterfield Publishers, Lanham, 2008.

Bardi, L. et al., How to Create a Transnational Party System (European Union Democracy Observatory for the European Parliament. AFCO Committee), EUDO, Istituto Universitario Europeo, San Domenico di Fiesole, Florence, 2010.

Batory, A., "Hungary", in Gagatek, 2010, op. cit.

Beckett Weaver, E., "The Communist Legacy? Populist but not Popular - The Foreign Policies of the Hungarian Radical Right", in Schari Liang, 2007, op. cit.

Bell, D.S., "The Confederal Group of the United Left-Nordic Left", in Bell, D.S., Lord, C. (eds.), Transnational Parties in the European Union, Ashgate, Aldershot, 1998.

Bellucci, P., Garzia, D., Rubal, M., “IImporta Europa en las elecciones europeas? Un modelo explicativo de las elecciones del 2009 al Parlamento Europeo", in Revista Española de Investigaciones Sociológicas, no. 137, JanuaryMarch 2012.

Benedetto, G., Quaglia, L., "The Comparative Politics of Communist Euroscepticism in France, Italy and Spain”, in Party Politics, vol. 13, no. 4, 2007.

Betz, H.G., "Conditions Favouring the Success and Failure of Radical Right-Wing Populist Parties in Contemporary Democracies", in Mény, Y., Surel, Y. (eds.), Democracies and the Populist Challenge, Palgrave, London, 2002.

Betz, H., La droite populiste en Europe. Extrême et démocratie?, CEVIPOF/ Autrement, Paris, 2004.

Blaise, P., Moreau, P. (dir.), Extrême droite et national-populisme en Europe de l'Ouest. Analyse par pays et approches transversales, CRISP, Brussels, 2004. 
Barnschier, S., "Unis contre la mondialisation? Une analyse de la convergence programmatique des partis populistes de droite européens", in Revue internationale de politique comparée, vol. 12, no. 4, 2005.

Bosco, A., Comunisti. Trasformazioni di partito in Italia, Spagna e Portogallo, Il Mulino, Bologna, 2000.

Botella, J., Ramiro, L. (eds.), The crisis of communism and party change. The evolution of west European communist and post-communist parties, ICPS, Barcelona, 2003.

Bozóki. A., Ishiyama, J.T. (eds.), The Communist Successor Parties of Central and Eastern Europe, M.E. Sharpe, Armonk, 2002.

Brack, "Quelle opposition au sein du Parlement européen?", in Crespy, Petithomme, 2009, op. cit.

Braun, D., Mikhaylou, S., Schmitt, H. (eds.), "European Parliament Election Study 2009", in Manifesto Study data, Advance Release, EES, 2009 (user beware/pre-release B), 22-7-10, www.piredu.eu.EES.

Manifesto Study Documentation Advance Release, 2009 (user beware/prerelease B), 22-7-10, www.piredu.eu.

Bressanelli, E., Calderaro, A., Piccio, D., Stamati, F., "Italy”, in Gagatek, 2010, op. cit.

Brunsbach, S., John, S., Werner, A., "Germany”, in Gagatek, 2010, op. cit.

Brustier, G., Huelin, J.P., Voyage au bout de la droite. Des paniques morales è la contestation droitière, Mille et une nuits/Fayard, Paris, 2011.

Caravita, B. (ed.), Le elezioni del Parlamento europeo del 2009, Jovene editore, Naples, 2009.

Carey, S., "Undivided Loyalties: Is National Identity an Obstacle to European Integration?", in European Union Politics, vol. 3, no. 4, 2002.

Carter, E., The extreme right in Western Europe. Success or failure?, Manchester University Press, Manchester, 2005.

Casals, X. (ed.), Political survival on the extreme right. European movements between the inherited past and the need to adapt to the future, ICPS, Barcelona, 2005.

Carter, E., Loomes, G., Lundberg, T.C., "United Kingdom”, in Gagatek, 2010, op. cit.

Casal, F., Ferrín, M., Pardos-Prado, S., "Spain”, in Gagatek, 2010, op. cit.

Cassetti, L., Ricci, S., "Il Portogallo alle elezioni europee del 2009: prevale l'astensionismo", in Caravita, op. cit.

Charalambous, G., "Le Parti progressiste du peuple travailleur (AKEL)", in De Waele, Seiler, op. cit.

Chiche J., De Boissieu, L., "Dossier documentaire (Les élections européennes de juin 2009)", in Revue internationale de politique comparée, vol. 16, no. 4, 2009.

Chirumbolo, A., Mayer, N., De Witte, H., "Do right-and left-wing extremists have anything in common?", in Klande-Mans, Mayer, 2006, op. cit. 
Christophorou, CH., "Cyprus”, in Gagatek, 2010, op. cit.

Clementi, F., "Le elezioni europee nel Regno Unito: il tracollo laburista fagocita il (già assai basso) europeismo britannico", in Caravita, op. cit.

Coosemans, T., "Les résultats des élections européennes de juin 2009 dans les États membres", in Courrier hebdomaire CRISP, no. 2038, 2009a.

Coosemans, T., "La composition du Parlement européen issu des élections de juin 2009", in Courrier hebdomaire CRISP, no. 2039, 2009 b.

Coosemans, T., "La composition du Parlement Européen élu en juin 2009 et les nouveaux rapports de force entre ses groupes politiques", in Revue du Marché commun et de l'Union européenne, no. 535, February 2010.

Corbett, R., Jacobs, F., Shackleton, M., The European Parliament, John Harper Publishing, London, 2011.

Cosseron, S. (dir.), Le dictionnaire de l'extrême gauche, Larousse, Paris, 2007.

Costa, O., Brack, N., "The Role(s) of the Eurosceptics MEPs", in Fuchs, MagniBerton, Roger, 2009, op. cit.

Courtois, S., Andolfatto, D., "France. The Collapse of the House of Communism", in Backes, Moreau, 2008, op. cit.

Crespy, A., "La cristallisation des résistances de gauche à l'integration européenne, les logiques de mobilisation dans la campagne reférendaire française de 2005", in Revue internationale de politique comparée, vol. 15, no. 4, 2008.

Crespy, A., "Euroscepticism in the European Parliament Elections of 2009: Country Report France and Belgium”, in RECON Work Package, no. 5, 2009.

Crespy, A., Petithomme, M., L'Europe sous tensions. Appropiation et contestation de l'intégration européenne, L'Harmattan, Paris, 2009.

Cunha, C., "Few but Pure and Good Members are Preferred to a Mass Party - The Portuguese Communist Party's Continued Orthodoxy", in Backes, Moreau, 2008, op. cit.

De Boissieu, L., "Le processus d'intégration des partis politiques français dans le système partisan européen", in Revue internationale de politique comparée, vol. 16, no. 4, 2009.

De Vries, Ch.E., Edwards, E.E, “Taking Europe to its Extremes: Extremist Parties and Public Euroscepticism", in Party Politics, vol. 15, no. 1, 2009.

De Waele, J.M., Vieira, M., "La famille de la gauche anticapitaliste en Europe occidentale. Une approche comparative (1989-2009)", in De Waele, J.M., Seiler, D.L. (dir.), Les partis de la gauche anticapitaliste en Europe, Economica, Paris, 2012.

De Wilde, P., "Euroscepticism in the European Parliament Elections of 2009: Country Report The Netherlands", in RECON Work Package, no. 5, 2009.

De Wilde, Trenz, H.-J., Michailidou, A., "Contesting EU Legitimacy. The Prominence, Content and Justification of Euroscepticism during 2009 EP Election Campaigns", in RECON Online Working Papers, no. 22, 2010. 
De Winter, L., "The Vlaams Blok: the Electorally best Performing Rightextremist Party in Western Europe", in Casals, 2005, op. cit.

De Winter, Gómez-Reino, M., "Les partis autonomistes: vers la disparition de l'avantage des élections européennes", in Revue internationale de politique comparée, vol. 16, no. 4, 2009.

Deloy, C., Reynié, D., "Les élections européennes confirment la suprématie de la droite dans l'Union", Fondation pour l'Innovation Politique, in Innovation Politique 2011, PUF, Paris, 2010.

Déloye, Y. (ed.), Dictionnaire des élections européennes, Economica, Paris, 2005.

Delwit, P., Poirer, Ph. (dir.), Extrême droite et pouvoir en Europe. The extreme right parties and power in Europe, Éditions de l'Université de Bruxelles, Brussels, 2007.

Dubé, S., Magni-Berton, R., "How Does Income Influence National and European Identity”, in Fuchs, Magni-Berton, Roger, 2009, op. cit.

Dunphy, R., Contesting capitalism? Left parties and European integration, Manchester University Press, Manchester, 2004.

Dupoirer, E., “L'européanisation des élections européennes? Ce que nous apprennent les élections de juin 2009", in Revue internationale de politique comparée, vol. 16, no. 4, 2009.

Eichenberg, R.C., Dalton, R.J., "Post-Maastricht Blues: The Transformation of Citizen Support for European Integration, 1973-2004", in Acta Politica, vol. 42, no. 2-3, 2007.

Ennser, L., "The homogeneity of West European party families: The radical right in comparative perspective", in Party Politics, no. 2, vol. 18, 2012.

Ersson S., "Post-Communism and Leftists Parties in Two Scandinavian Countries after 1989 - The Cases of Denmark and Sweden”, in Backes, Moreau, 2008, op. cit.

Evans, J.A.J., "'La politique du dehors avec les raisons du dedans': Foreign and Defence Policy of the French Front National", in Schari Liang, 2007, op. cit.

Fabbrizzi, F., "Europa, la strada della Turchia passa per Cipro", in Caravita, 2009, op. cit.

Flood, C., "Euroscepticism: A Problematic Concept", in Paper UA-CES, 2a Conferencia Anual y 7a Conferencia de Investigación (September), Quenn's University, Belfast, 2002.

Fotia, M., Il ritorno dell'estrema destra. Il Fronte nazionale in Francia, Ed. Lavoro, Roma, 1995.

Franck, CH., Isnard, L., "Un vote sanction asymétrique", in Revue internationale de politique comparée, vol. 16, no. 4, 2009.

Frólich-Steffen and Rensmann, L., "Conditions for failure and success of rightwing populist parties in public office in the New European Union", in Delwit, Poirer, 2007, op. cit. 
Frosina, L., "Il voto europeo sanziona anche la Spagna socialista di Zapatero", in Caravita, 2009, op. cit.

Fuchs, D., Guinaudeau, I., Schubert, S., "National Identity, European Identity and Euroscepticism", in Fuchs, Magni-Berton, Roger, 2009, op cit.

Fuchs, D., Magni-Berton, R., Roger, A. (eds.), Euroescepticism. Images of Europe among mass publics and political elites, Barbara Budrich Publishers, Opladen (MI), 2009.

Gabel, M. J., Interest and Integration. Market liberalization, public opinion, and European Union, Ann Arbor Press, University of Michigan, Michigan, 1998a.

Gabel, M. J., "Economic Integration and Mass Politics: Market Liberalization and Public Attitudes in the European Union", in American Journal of Political Science, vol. 42, no. 3, July 1998b.

Gagatek, W. (ed.), The 2009 Elections to the European Parliament. Country Reports, EUI/IUE, Florence, 2010a.

Gagatek, W., "Campaigning in the European Parliament elections", in Gagatek, 2010b, op. cit.

Gagatek, W., "The political composition of the new European Parliament", in Gagatek, 2010 c, op. cit.

Gagatek, W., Trechsel, H., Breuer, F., "Preface: Bringing the European Parliament election results closer to the citizens", in Gagatek, 2010, op. cit.

Gallagher, T., Modern Romania. The End of Communism, the Failure of Democratic Reform, and the Theft of a Nation, New York University Press, New York, 2008.

Gibson, R. K., The Growth of Anti-Immigrants Parties in Western Europe, The Edwin Mellon Press, Lewinston (NY), 2002.

Giebler, H., Wüst, A.M., "Campaigning on an upper level? Individual campaigning in the 2009 European Parliament elections in its determinants", in Electoral Studies, vol. 30, no. 1, March 2011.

Goul Anderson, J., "Nationalism, New Right, and New Cleavages in Danish People's Party", in Schari Liang, 2007, op. cit.

Grzymala-Busse, A., Redeeming the Communist Past: The Regeneration of Communist Parties in East Central Europe, Cambridge University Press, Cambridge, 2002.

Haesly, R., "Eurosceptics, Europhiles and Instrumental Europeans: European Attachment in Scotland and Wales", in European Union Politics, vol. 2, no. 2, 2001.

Hainsworth, P., The Extreme Right in Western Europe, Routledge, New York, 2008.

Hainsworth, P., O'Brien, C., Mitchell, P., "Defending the nation: the politics of Euroscepticism on the French right”, in European Studies, no. 22, 2004. 
Halikiopoulou, D., Nanou, K., Vasilopoulou, S., "The paradox of nationalism: The common denominator of radical right and radical left euroscepticism", in European Journal of Political Research, vol. 51, no. 4, 2012.

Hanley, D., Beyond the Nation State. Parties in the Era of European Integration, Palgrave/Macmillan, Basingstoke, 2008.

Hanley, D., "Les élections européennes de juin 2009 au Royaume-Uni: des élections pas tout à fait de second ordre?", in Revue internationale de politique comparée, vol. 16, no. 4, 2009.

Hanley, S., The New Right in the New Europe. Czech transformation and rightwing politics 1989-2006, Routledge, London, 2008b.

Harmsen, K., Spiering, M. (eds.), Euroscepticism: party politics, national identity and European integration, Rodopi, Amsterdam/New York, 2004.

Harmsen, R., "Euroscepticisme", in Déloye, 2005, op. cit.

Harrison, S., "Extrême droite en Europe", in Déloye, 2005a, op. cit.

Harrison, S., "Extrême gauche en Europe", in Déloye, 2005b, op. cit.

Hastings, M., "Les partis de la gauche radicale en Scandinavie", in De Waele, Seiler, op. cit.

Hayward, K., Irish nationalism and European integration. The official redefinition of the island of Ireland, Manchester University Press, Manchester, 2009.

Heine, S., Une gauche contre l'Europe? Les critiques radicales et altermondialistes contre l'Union européenne en France, Éditions de l'Université de Bruxelles, Brussels, 2009.

Heller, M., "Euroscepticism in the European Parliament. Elections of June 2009. Country Report: Hungary", in RECON-Working Paper, no. 5, 2009.

Hix, S., "Euroscepticism as Anti-Centralization: A Rational Choice Institutionalist Perspective", in Party Politics, vol. 8, no. 1, 2007.

Hix, S., Marsh, M., "Punishment or Protest? Understanding European Parliament Elections", in Journal of Politics, vol. 69, no. 2, 2007.

Hloušek, V., Pšeja, P., "Europeanisation of Political Parties and the Party System in the Czech Republic", in Haughton, T. (ed.), Party Politics in Central and Eastern Europe. Does EU Membership Matter?, Routledge, London, 2011.

Hobolt, S.B., Spoon, J.J., Tilly, J., “A vote against Europe? Ex-plaining defection at the 1999 and 2004 European Parliament Elections", in British Journal of Political Science, vol. 39, no. 1, 2009.

Holmes, M., The Eurosceptical Reader 2, Palgrave, Basingstoke, 2002.

Hooghe, L., "What Drives Euroskepticism?: Party-Public Cueing, Ideology and Strategic Opportunity", in European Union Politics, vol. 8, no. 1, 2007.

Hooghe, L., Marks, G., "Sources of Euroscepticism", in Acta Pollitica, vol. 42, no. 2-3, 2007. 
Hooghe, L., Marks, G., "A Postfunctionalist Theory of European Integration: From Permissive Consensus to Constraining Dissensus", in British Journal of Political Science, vol. 39, no. 1, 2008.

Hooghe, L., Marks, G., Wilson, C.J., "Does Left/Right Structure Party Positions on European Integration?", in Comparative Political Studies, no. 35, 2002.

Hoppe, M., "The Europeanisation of Nationalist Parties?", in Karolewski, Suszyki, 2007, op. cit.

Hudson, K., European Communism since 1989. Towards a New European Left?, Macmillan, Basingstoke, 2000.

Ignazi, P., L'estrema destra in Europa, Il Mulino, Bologna, 2000.

Ignazi, P., Extreme Right Parties in Western Europe, Oxford University Press, Oxford, 2003.

Ishiyma, J.T., "Strange bed fellows: explaining political cooperation between communist-successor parties and nationalist in Eastern Europe", in Nation and Nationalism, vol. 1, no. 4, 1998.

Ivarsflaten, E., "What Unites Right-Wing Populists in Western Europe? ReExamining Grievance Mobilisation Models in Seven Successful Cases", in Comparative Political Studies, no. 41, 2008.

Jalaili, C., Silva, T., "Everyone Ignores Europe? Party campaigns and Media Coverage in the 2009 European parliament Elections", in Maier, Strömbäck, Lee Kaid, op. cit.

Jalali, C., Lisi, M., “Quand le changement semble dangereux: l'évolution du Parti communiste portugais", in De Waele, Seiler, op. cit.

Joensson, J., "Sweden", in Gagatek, 2010, op. cit.

Jones, C.A., "The Legal end Institutional Framework of the 2009 European Parliament Elections in the Shadow of the Lisbon Treaty", in Maier, Strömbäck, Lee Kaid, op. cit.

Kalyvas, S.N., Marantzidis, N., "The Two Paths of the Greek Communist Movement (1985-2001)", in Botella, Ramiro, 2003, op. cit.

Kárníková, A., "Czech Republic”, in Gagatek, 2010, op. cit.

Karolewski, I.P., Suszyki, A.M., "Regionalism, Nationalism, and European Integration", in Karolewski, I.P., Suszyki, A.M (eds.), Nationalism and European Integration, Continuum, New York/London, 2007.

Kitschelt, H., Mc Gann, A.J., The Radical Right in Western Europe. A Comparative Analysis, The University of Michigan Press, Ann Arbor (MI), 1995.

Kitschelt, H., et al., Post-Communist Party Systems: Competition, Representation, and Inter-Party Cooperation, Cambridge University Press, Cambridge, 1999.

Klandermans, B., Mayer, N. (eds.), Extreme Right Activist in Europe. Trough the magnifying glass, Routledge, London, 2006. 
Kopecky, P., Mudde, C., "The Two Sides of Euroscepticism: Party Positions on European Integration in East Central Europe", in European Union Politics, vol. 3, no. 3, 2002.

Krouwel, A., Abts, K., "Varieties of Euroscepticism and Populist Mobilisation: Transforming Attitudes from Mild Euroscepticism to Harsh Eurocynism", in Acta Politica, vol. 42, no. 2-3, 2007.

Kufer, A., "Images of Europe - the meaning and perception of 'Europe' by citizens of EU member states”, in Fuchs, Magni-Berton, Roger, 2009, op. cit.

Kuhn, T., Wolkenstein, F., Perlot, F., Meyer, S., “Austria”, in Gagatek, 2010, op. cit.

Lacroix, J., Coman, R., Les résistances à l'Europe: cultures nationales, idéologies et stratégies d'acteurs, Éditions de l'Université de Bruxelles, Brussels, 2007.

Ladrech, R., Europeanisation and National Politics, Palgrave/MacMillan, Houndsmills/Basingstoke/Hampshire, 2010.

Laible, J., Separatism and Sovereignty in the new Europe. Party Politics and the meanings of Statehood in a Supranational Context, Palgrave/Macmillan, Houndmills/Basingstoke/Hampshire, 2008.

Landwehrlen, Th., "Die Linke. L'émergence du nouveau parti de la gauche antilibérale allemande: une menace pour le SPD, un défi pour la gouvernabilité de la République féderale", in Working Papers, no. 289, ICPS, Barcelona, 2010.

Landwehrlen, Th., "Die Linke” in De Waele, Seiler, op. cit.

Lavelle, A., The Death of Social Democracy. Political Consequences in the 21st Century, Ashgate, Aldershot/Hampshire, 2008.

Leconte, C., L'Europe face au défi populiste, PUF, Paris, 2005.

Leconte, C., Understanding Euroscepticism, Palgrave/Macmillan, Houndmills/ Basingstoke/Hampshire, 2010.

Lewis, R., "The Myth of Europe", in Holmes, 2002, op. cit. Liang, C.C. (ed.), Europe for the Europeans. The Foreign and Security Policy of the Populist Right, Ashgate, Aldershot, 2007.

Liberati, "Elezioni europee 2009 in Germania: tra aspirazioni europeiste e prove generali per le elezioni politiche interne", in Caravita, op. cit.

Lubbers, M., Scheepers, P., "Political versus Instrumental Euroscepticism: Mapping Scepticism in European Countries and Regions", in European Union Politics, vol. 6, no. 2, 2005.

Lubbers, M., Scheepers P., "Euroscepticism and extreme voting patterns in Europe", in Loosveldt, G., Swyngedou, M., Cambre, B. (eds.), Measuring meaningful data in social research, Acco, Lovaina, 2007.

Lubbers, M., Scheepers, P., "Divergent trends of Euroscepticism in countries and regions of the European Union", in European Journal of Political Research, vol. 49, 2010.

Lucardie, P., Voerman, G., "The organisational and ideological development of Green left", in Botella, Ramiro, 2003, op. cit. 
Lyubenov, M., "Bulgaria”, in Gagatek, 2010, op. cit.

Maier, M., Strömbäck, Lee Kaid, L. (eds.), Political Communication in European Parliamentary Elections, Ashgate, Farnham/Surrey, 2011.

Mair, P., "Political opposition and the European Union", in Government and Opposition, vol. 42, no. 1, 2007.

Manners, I., "Another Europe is possible: Critical Perspectives on European Union Politics”, in Jørgensen, K.E., Pollack, M.A., Rosamond, B. (eds.), Handbook of European Union Politics, Sage, London, 2006.

Marantzidis, N., "The Communist Party of Greece after the Collapse of Communism (1989-2006). From Proletarian Internationalism to EthnoPopulism", in Backes, Moreau, 2008, op. cit.

March, L., Mudde, C., "What's left of the radical left? The European radical left since 1989: decline and mutation", in Comparative European Politics, vol. 1, no. 3, 2005.

Mareš, M., "Communist and Post-Communist Parties in the Czech Republic and in Slovakia", in Backes, Moreau, 2008, op. cit.

Mc Donell, D., Newell, J.L., "Outsider parties in government in Western Europe”, in Party Politics, vol. 17, no. 4, 2011.

Mc Elroy, G., Benoit, K., "Policy positioning in the European Parliament", in European Union Politics, no. 1, vol. 13, 2012.

Mc Laren, L. M., "Opposition to European integration and fear of loss of national identity: Debunking a basic assumption regarding hostility to the integration project", in European Journal of Political Research, vol. 43, no. 6, 2004.

Mezzanotte, P., "Svezia. Elezioni al Parlamento europeo 2009”, in Caravita, 2009, op. cit.

Michailidiou, A., "Euroscepticism in the European Parliament Elections of 2009: Country Report. The United Kingdom”, in RECON Work Package, no. 5, 2009.

Milner, S., "For an alternative Europe: Euroscepticism and the French left since the Maastricht treaty", in European Studies, no. 20, 2004.

Minkenberg, M., "The Renewal of Radical Right: Between Modernity and AntiModernity", in Government and Opposition, vol. 35, no. 2, 2000.

Mößner, A., "Cognitive Mobilization, Knowledge and Efficacy as Determinants of Euroscepticism”, in Fuchs, Magni-Berton, Roger, 2009, op. cit.

Mudde, C., Populist radical right parties in Europe, Cambridge University Press, Cambridge, 2007.

Munkøe, M., "Denmark", in Gagatek, 2010, op. cit.

Nedelcheva, M., "Euroscepticism and Party System Change: Bulgaria, Romania and the Czech Republic", in Fuchs, Magni-Berton, Roger, 2009, op. cit.

Negrine, R., Steka, V., Fialová, M., "Campaigning in but nor for Europe: European campaign strategies in the UK and the Czech Republic", in Maier, Strömbäck, Lee Kaid, op. cit. 
Neller, K., Thaidigsmann, S.I., "Right Wing Parties and Euroscepticism in France and Germany", in Fuchs, Magni-Berton, Roger, 2009, op. cit.

Netjes, C.E., Edwards, E., "Taking Europe to its Extremes: Examining cueing effects of right-wing populist parties on public opinion regarding European integration", (Discussion Paper SP IV), WZB, Berlin, 2005.

Neumayer, L., "Euroscepticism as a political label: The use of European Union issues in political competition in the new member States", in European Journal of Political Research, vol. 47, no. 2, 2008.

Neumayer, L., Roger, A., Zalawski, F. (dir.), L'Europe contestée. Espaces en enjeux des positionnements contre l'integration européenne, Éditions Michel Houdiard, Paris, 2008.

Norris, P., Derecha radical. Votantes y partidos en el mercado electoral, Akal, Madrid, 2009.

OSCE, Election to the European Parliament. Exploratory Mission Report, OSCE/ODHIR, 2009.

Packam, K., Klepatz, J., "Euroscepticism in the European Parliament Elections of 2009: Country Report. Germany”, in RECON Work Package, no. 5, 2009.

Pancheri, G., "Per 1'Ungheria, in fondo a destra", in Caravita, 2009, op. cit.

Papadimitriou, D., Phinnemore, D., Romania and the European Union. From marginalisation to membership, Routledge, London, 2008.

Pérez, I., La oposición a la Unión Europea en el sur de Europa: los casos español, portugués, griego e italiano, Tesis Doctoral, Universidad de Barcelona, 2008.

Perottino, M., "Le parti communiste tchèque entre continuité et rupture", in De Waele, Seiler, op. cit.

Perrineau, P. (ed.), Les croisés de la societé fremée: L'Europe des extrêmes droites, L'Aube Essai, Paris, 2001.

Perrineau, P., "Les élections européennes de juin 2009 en France: des élections de second ordre ou de reclassement?", in Revue internationale de politique comparée, vol. 16, no. 4, 2009.

Petithomme, M., "France", in Gagatek, 2010.

Poirier, Ph., “Les nouvelles droites et le régime politique de l'Union européenne de 1979 à 2004", in Delwit, Poirer, 2007, op. cit.

Raycheva, L., Róka, J., "Similarities and Differences in Transformational Democracies: EP Campaigns in Bulgaria and Hungary”, in Maier, Strömbäck, Lee Kaid, op. cit.

Raniolo, F., I partiti conservatori in Europa occidentale, Il Mulino, Bologna, 2000.

Reif, K.H., Schmitt, H., "Nine Second-Order Elections: A Conceptual Framework for the Analysis of European Election Results", in European Journal of Political Research, vol. 8, no. 3-4, 1980. 
Ridola, P., "Il voto europeo del 6 e 7 giugno: la 'sfera pubblica europea', l'integrazione multilivello e le sfide della complessità”, in Caravita, 2009.

Rodomonte, M. G., "La Dinamarca al voto: il Governo tiene ma avanzano le ali estreme", in Caravita, 2009, op. cit.

Rodomonte, M. G., Rosa, G., Sterpa, A., "Italia, il bipolarismo tiene alla prova delle elezioni europee", in Caravita, 2009, op. cit.

Rodríguez-Aguilera, C., "Partidos de ámbito no estatal e integración europea. Los casos de Convergència i Unió, el Scottish National Party y la Lega Nord", in Papers, no. 92, 2009.

Rodríguez Jiménez, J. L., ¿Nuevos fascismos? Extrema derecha y neofascismo en Europa y Estados Unidos, Península, Barcelona, 1998.

Roger, A., "The Impact of European Policies on National Political Parties: a theoretical outlook", in Fuchs, Magni-Berton, Roger, 2009, op. cit.

Roncarolo, F., "Mediatizing Europe while Ignoring the European Election: The Paradox of the Italian Case", in Maier, Strömbäck, Lee Kaid, op. cit.

Rovny, J., "Conceptualizing Party-Based Euroscepticism: Magnitude and Motivations", in Collegium no. 29 (monogr. invierno: "Does Euroscepticism have passport?"), 2004.

Sánchez-Cuenca, I., "The Political Basis of Support for European Integration”, in European Union Politics, vol. 1, no. 2, 2000.

Santana Pereira, J., "Portugal" en Gagatek, 2010, op. cit.

Sauger, N., "Sur la mutation contemporaine des structures de la compétition partisane en France: les partis de droite face à l'integration européenne", in Politique européenne, no. 15, 2005.

Sawiki, J., "Le elezioni europee del 2009 nella Repubblica Ceca alla ricerca della ragione nell'instabilità", in Caravita, 2009, op. cit.

Schain, M., Zolberg, A., Hossey, P. (eds.), Shadows over Europe: The Development and Impact of the Extreme Right in Western Europe, Palgrave/Macmillan, New York, 2002.

Schari Liang, C. (ed.), Europe for the Europeans. The Foreign and Security Policy of the Populist Radical Right, Ashgate, Aldershot/Hampshire, 2007.

Schuck, A.R.T., Xezonakis, G., Elenbaas, M., Banduc-CI, S.A., De Vreese, C.H., "Party contestation and Europe on the news agenda: The 2009 European Parliamentary Elections", in Electoral Studies, vol. 30, no. 1, 2011.

Sczerbiak, A., Taggart, P., "Introduction: Opposing Europe? The Politics of Euroscepticism in Europe" en Sczerbiak, A., Taggart, P. (eds.), Opposing Europe? The Comparative Party Politics of Euroscepticism, II vol., Oxford University Press, Oxford, 2008 I a.

Sczerbiak, A., Taggart, P., "Conclusion: Opposing Europe? Three Patterns of Party Competition in Europe”, en Sczerbiak, A., Taggart, P., op. cit., 2008 I b. 
Sczerbiak, A., Taggart, P., "Introduction: Researching Euroscepticism in European Party Systems. A Comparative and Theoretical Research Agenda", in Sczerbiak, A., Taggart, P., op. cit., 2008 II a.

Sczerbiak,A., Taggart, P., "Theorising Party-Based Euroscepticism. Problems of Definition, Measurement and Causality", in Sczerbiak, A., Taggart, P., op. cit., 2008 II b.

Seidendorf, S., "Contesting Europe: the constitutive impact of discursive dynamics on national referendum campaigns", in European Political Science Review, vol. 2, no. 3, 2010.

Siegers, P., "EU Performance and Euroscepticism", in Fuchs, Magni-Berton, Roger, op. cit., 2009.

Sigalas, E., Monkre, M., Pollak, J., Slominski, P., Bátora, J., “Democracy Models and Parties at the EU Level. Empirical Evidence from the Adoption of the 2009 European Election Manifestoes", in RECON On line Working Papers, no. 13, 2010.

Simmons, H. G., The French National Front. The Extremist Challenge to Democracy, Westview Press, Boulder (Col.), 1996.

Simón, M.A. (ed.), La extrema derecha en Europa desde 1945 a nuestros dias, Tecnos, Madrid, 2007.

Sitter, N., "Opposing Europe: Euro-Scepticism, Opposition and Party Competition", in Working Paper, no. 56, Brighton, 2002.

Smets, K., Van Berendoncks, K., Van Hecke, S., "Belgium”, in Gagatek, 2010, op. cit.

Seenbergen, M.R., Scott, D.J., "Contesting Europe? The Salience of European Integration as a Party Issue", in Marks, G., Steenbergen, M. (eds.), European Integration and Political Conflict, Cambridge University Press, New York, 2008.

Steorgiu, A., "The Communist Party of Cyprus-AKEL", in Backes, Moreau, 2008, op. cit.

Sterpa, A., "Il cammino della democrazia greca verso l'alternanza politica", in Caravita, 2009, op. cit.

Sterpa, A., Scoppola, F., "Il nuovo Parlamento europeo tra innovazioni istituzionali e dinamiche politiche", in Caravita, 2009, op. cit.

Swyngedow, M., Abts, K., Van Craen, M., "Our Own People First in a Europe of peoples: The International Policy of the Vlaams Blok", in Schari Liang, 2007, op. cit.

Taggart, P., "A Touchstone of Dissent: Euroscepticism in Contemporary West European Party Systems", in European Journal of Political Research, vol. 37, no. 33, 1998.

Taggart, P., Sczerbiak, A., "Contemporary Euroscepticism in the party systems of the European Union candidate States of Central and Eastern Europe", in European Journal of Political Research, vol. 43, no. 1, 2004. 
Tarchi, M., "Radicalismo de derecha y neofascismo en la Europa de postguerra", in Antón Mellón, J. (ed.), Orden, jerarquía y comunidad. Fascismos y postfascismos en la Europa contemporánea, Tecnos, Madrid, 2002.

Tarchi, M., "Recalcitrant Allies: The conflicting Foreign Policy Agenda of the Alleanza Nazionale and the Lega Nord", in Schari Liang, 2007, op. cit.

Tierski, R., Euroskepticism: A Reader, Rowman and Littlefield, Lanham (MA), 2001.

Todor, A., "Romania", in Gagatek, 2010, op. cit.

Todorov, A., "Les élections européenes de juin 2009 en Bulgarie: la confirmation de l'éclatement du système partisan", in Revue internationale de politique comparée, vol. 16, no. 4, 2009.

Todorov, A., De Waele, J.-M., “Les élections européennes de juin 2009 dans les pays de l'Europe centrale et orientale: des résultats moins spécifiques qu'il n'y paraît", in Revue internationale de politique comparée, vol. 16, no. 4, 2009.

Togna, M., "Belgio: elezioni più europee in tempo di crisi e prove tecniche di astensionismo", in Caravita, 2009, op. cit.

Torcal, M., Font, J. (eds.), Las elecciones europeas de 2009, CIS, Madrid, 2012.

Trenz, H.-J., De Wilde, P., "Denouncing European Integration. Euroscepticism as Reactive Identity Formation", in RECON On line Working Papers, no. 10, 2009.

Trechsell, A. H., "How much 'second-order' were the European Parliament elections 2009?”, in Gagatek, 2010, op. cit.

Van Der Brug, W., Fennema, M., Tillie, J., "Anti-immigrant parties in Europe: ideological or protest vote?", in European Journal of Political Research, no. 37, 2000.

Van Der Brug, W., Fennema, M., "The Support Base of Radical Right Parties in the Enlarged European Union", in Schmitt, H. (ed.), European Parliament Elections after Eastern Enlargement, Routledge, London, 2010.

Van Der Eijk, C., Franklin, M.N., Choosing Europe?: The European Electorate and National Politics in the Face of Union, Michigan University Press, Ann Arbor, 1996.

Van Der Eijk, C., Franklin, M.N., "Potential for Contestation on European Matters at National Elections in Europe", in Marks, G., Steenbergen, M.R. (eds.), European Integration andPolitical Conflict, Cambridge University Press, New York, 2004.

Van Ham, Smets, K., "The Netherlands", in Gagatek, 2010, op. cit.

Van Hüllen, R., "Transnational cooperation of Post-Communist Parties", in Backes, Moreau, 2008, op. cit.

Van Spanje, J., "Contagious Parties: Anti-Immigration Parties and their Impact on other Parties' Immigration Stances in contemporary Western Europe", in Party Politics, vol. 16, no. 5, 2010. 
Van Spanje, J., De Vreese, C., "So what's wrong with the EU? Motivations underlying the Eurosceptic vote in the 2009 European elections", in European Union Politics, vol. 12, no. 3, 2011.

Vannucci, A., "Elezioni europee in Bulgaria: GERB, una vittoria come viatico per la conquista del governo", in Caravita, 2009, op. cit.

Vannucci, A., "In Romania sostanziale pareggio tra i partiti maggiori, vincono astensionismo ed estrema destra", in Caravita, 2009, op. cit.

Varios, "L'extreme droite en Europe", in Pouvoirs, no. 87, 1998.

Vasiliopoulou, S., "Varieties of Euroscepticism: The case of the European Extreme Right", in Journal of Contemporary European Research, vol. 5, no. 1, 2008.

Vasiliopoulou, S., "Greece”, in Gagatek, 2010, op. cit.

Villany, M.C., "Olanda: l'ascesa della estrema destra anti-islamica e antieuropeista", in Caravita, 2009, op. cit.

Virchow, F., "The Aims and Objections of the Austrian Far Right in Foreign and Military Policies", in Schari Liang, 2007, op. cit.

Verney, S., "An Exceptional Case? Party and Popular Euroscepticism in Greece, 1959-2009”, in South European Society and Politics, vol. 16, no. 1, 2011.

Voerman, G., "The Disappearance of Communism in the Netherlands", in Backes, Moreau, 2008, op. cit.

Wessels, B., "Discontent and European identity: Three types of Euroscepticism", in Acta Politica, vol. 42, no. 2-3, 2007.

Williams, M. H., The Impact of Radical Right-Wing Parties in West European Democracies, Palgrave/Macmillan, New York, 2006.

Zei, A., "Le elezioni europee 2009 in Austria", in Caravita, 2009, op . cit. 


\section{Acronyms}

\section{Acronyms for political formations subject to this research}

\section{Radical Right}

DF Folkeparti Dansk / Danish Popular Party (Denmark)

FN Front National / National Front (France)

FPÖ Freiheitliche Partei Österreichs / Austrian Freedom Party (Austria)

JMM Jobbik Magyarországért Mozgalom / Movement for a Better Hungary (Hungary)

LAOS Laikos Orthodoxos Synagermos / Popular Orthodox Rally (Greece)

LN Lega Nord / Northern League (Italy)

NSA Natsionalen Săyuz Ataka / National Union Attack

(Bulgaria)

PRM Partidul România Mare / Greater Romania Party (Romania)

PVV Partij voor de Vrijheid / Freedom Party (Holland)

VB Vlaams Belang / Flemish Interest (Belgium)

UKIP United Kingdom Independence Party (UK)

\section{Radical Left}

AKEL Anorthoiko Komma Ergazomenou Laou / Pro-Congressman Party of the Working People (Cyprus)

BE Bloc de Esquerda / Left Bloc (Portugal)

CDU-PCP Coligação Unitarian Democratic-Communist Party Português / Portuguese Unitarian Democratic Communist Coalition Party (Portugal)

DL Die Linke / The Left (Germany)

FG Front de Gauche / Left Front (France)

IU Izquierda Unida / United Left (Spain)

KKE Kommounistiko Komma Elladas / Communist Party of Greece (Greece)

KSČM Komunistická Strana Čech to Moravy / Communist Party of Bohemia and Moravia (Czech Republic)

SF Sinn Féin (UK / Ireland) 
SYRIZA Synaspismos tis Rizospastis Aristeras / Radical Left Coalition (Greece)

VP Väntsterpartiet / Left Party (Sweden)

\section{Other acronyms}

AN Alleanza Nazionalel / National Alliance

ATTAC Association for the Taxation of Financial Transactions for the Aid of Citizens

AUE Single European Act

BNP British National Party

BZÖ Bündnis Zukunft Österreich / Alliance for the Future of Austria

CC.EE European Community

CRE European Conservatives and Reformists

EFD Europe of Freedom and Democracy

EURATOM European Atomic Energy Community

FIDESZ Fiatal Demokrátak Szövetsége / Alliance of Young Democrats

FYROM Former Yugoslav Republic of Macedonia

GERB Razvitie Europeysko Grazhdaniza na Balgariya / Citizens of Bulgarian Development

GUE/ NGL Gauche Unitaire Européenne / Nordic Green Leftl / European United Left / Nordic Green Left

ID Independence and Democracy

IN Northern Ireland

IVA Value Added Tax

LPR Liga Polskich Rodzin / League of Polish Families

MSI Movimento Sociale Italiano / Italian Social Movement

NI Not Enrolled

NPD Nationaldemokratische Partei Deutschland / German National Democratic Party

N-VA Nieuw-Vlaamse Alliantie / New Flemish Alliance

ODS Obcanská Demokratická Strana / Civic Democratic Party

ONU United Nations Organization

OSCE Organisation for Security and Cooperation in Europe

PAC Common Agricultural Policy

PC Communist Party

PCE Communist Party of Spain

PCF Parti Communiste Français / French Communist Party

PCI Communist Partito Italiano / Italian Communist Party

PdL Popolo della Liberta / People of Freedom 
PDS Partito Democratico della Sinistra / Democratic Party of the Left

PE European Parliament

PECO (CEEC) Central and Eastern European Countries PESC/PESD: (CFSP) Common Foreign and Security Policy / (EPSD) European Policy on Security and Defence

PIE Party of the European Left

PiS Prawo i Spawiedliwość / Law and Justice

PP Popular Party

PPC CFP

PPE/ DE European Popular Party / European Democrats

PRC Partito della Rifondazione Communist / Refoundation Party Communist

PSE Party of European Socialists

PSOE Spanish Socialist Workers Party

PSUC Unificat Partit Socialista de Catalunya / Unified Socialist Party of Catalonia

SED Einheitspartei Sozialistische Deutschlands / Unified German Socialist Party

TCUE Constitutional Treaty of the European Union

EU European Union

EMU Economic and Monetary Union

UEN Union for Europe of the Nations

USSR Union of Soviet Socialist Republics

V / ALE Greens / European Free Alliance 



\section{EUROCLIO - Published Books}

$\mathrm{N}^{\circ} 84$ - Economic Crisis and New Nationalisms. German Political Economy as Perceived by European Partners. Antonio Varsori \& Monika Poettinger (eds.), 2014.

$N^{\circ} 83$ - European Constitutionalism. Historical and Contemporary Perspectives. Alexandre Dupeyrix \& Gérard Raulet (eds.), 2014.

$N^{\circ} 82$ - Cross-Border Cooperation Structures in Europe. Learning from the Past, Looking to the Future. Luis Domínguez \& Iva Pires (eds.), 2014. № 81 - The European Community and the World. A Historical Perspective. Giuliana LASCHI (ed.), 2014.

$\mathrm{N}^{\circ} 80$ - Christian Democrat Internationalism. Its Action in Europe and Worldwide from Post World War II until the 1990s. Volume II: The Development (1945-1979). The Role of Parties, Movements, People. Jean-Dominique Durand (ed.), 2013.

$\mathrm{N}^{\circ} 79$ - Christian Democrat Internationalism. Its Action in Europe and Worldwide from Post World War II until the 1990s. Volume I: The Origins. Jean-Dominique Durand (ed.), 2013.

$\mathrm{N}^{\circ} 78$ - Investment Banking History. National and Comparative Issues (19th-21st centuries). Hubert Bonin \& Carlo Brambilla (eds.), 2013.

$N^{\circ} 77$ - Citizenship and Solidarity in the European Union. From the Charter of Fundamental Rights to the Crisis, the State of the Art. Mariana Canotilho, Pedro Madeira Froufe \& Alessandra Silveira (eds.), 2013.

$N^{\circ}$ 76- The OSCE: Soft Security for a Hard World. Competing Theories for Understanding the OSCE. Roberto Dominguez (ed.), 2013.

No 75 - Euroscepticism, Europhobia and Eurocriticism. The Radical Parties of the Right and Left vis-à-vis the European Union. Cesáreo Rodríguez-Aguilera de Prat, 2013.

$\mathrm{N}^{\circ} 74$ - Fermer les mines en construisant l'Europe. Une histoire sociale de l'intégration européenne. Nicolas VersChUEREN, 2012

$N^{\circ} 73$ - Reflets de la construction européenne. Réflexions, références et refus du débat sur l'Europe. Bertrand VAYSSIÈre (dir.), 2012.

$\mathrm{N}^{\circ} 72$ - The International Relations of Local Authorities. From Institutional Twinning to the Committee of the Regions: Fifty Years of European Integration History. Fabio ZuCCA, 2012.

No 71 - Histoire du Conseil de l'Europe (1949-2009). Birte WASSENBERG, 2012.

№ 70-The EU, Security and Transatlantic Relations. Finn LAURSEN (ed.), 2012.

N 69 - Européanisation au XXe siècle. Un regard historique / Europeanisation in the $20^{\text {th }}$ Century. The Historical Lens. Matthieu Osmont, Émilia Robin-Hivert, Katja Seidel, Mark Spoerer \& Christian Wenkel (dir./ eds.), 2012. 
$\mathrm{N}^{\circ} 68$ - Consensus and European Integration. An Historical Perspective / Consensus et intégration européenne. Une perspective historique. Daniela Preda \& Daniele PAsquinucci (eds./dir.), 2012.

N 67 - Générations de fédéralistes européens depuis le XIXe siècle. Individus, groupes, espaces et réseaux. Geneviève DuchenNne et Michel Dumoulin (dir.), 2012.

NN66 - Raymond Aron, penseur de l'Europe et de la nation. Giulio DE LıGıO (dir.), 2012.

$\mathrm{N}^{\circ} 65$ - Europe Twenty Years after the End of the Cold War. The New Europe, New Europes? / L'Europe vingt ans après la fin de la guerre froide. Nouvelle Europe, nouvelles Europes? Bruno ARCIDIACONO, Katrin Milzow, Axel Marion \& Pierre-Étienne Bourneuf (eds./dir.), 2012.

N 64 - Aux origines de la diplomatie européenne. Les Neuf et la Coopération politique européenne de 1973 à 1980. Maria Gainar, 2012.

N 63 - Europe and the Middle East. The hour of the East? Birte WASSENBERG \& Giovanni FALEG (eds.), 2012.

Nº 62 - Quelle architecture pour un code européen de droit international privé ? Marc Fallon, Paul Lagarde, Sylvaine Polllot-Peruzzetto (dir.), 2011.

Nº 61 - La construction d'un espace euro-méditerranéen. Genèses, mythes et perspectives. Houda Ben Hamouda et Mathieu Bouchard (dir.), 2012.

$\mathrm{N}^{\circ} 60$ - Innovations et transferts de technologie en Europe du Nord-Ouest aux XIXe et XXe siècles. Jean-François Eck et Pierre Tııı (dir.), 2011.

No 59 - Novel Outlooks on the Marshall Plan. American Aid and European Re-Industrialization. Fransceca Fauri \& Paolo Tedeschi (eds.), 2011.

$\mathrm{N}^{\circ} 58$ - Europe in the International Arena during the 1970s. Entering a Different World / L'Europe sur la scène internationale dans les années 1970. À la découverte d'un nouveau monde. Antonio VARSORI \& Guia Migani (eds./dir.), 2011.

No 57 - Cultures nationales et identité communautaire. Un défi pour I'Europe? I National Cultures and Common Identity. A Challenge for Europe? Marloes BeERS \& Jenny RAfLIK (dir./eds.), 2010.

$\mathrm{N}^{\circ} 56$ - Les trajectoires de l'innovation technologique et la construction européenne. Des voies de structuration durable? / Trends in Technological Innovation and the European Construction. The Emerging of Enduring Dynamics? Christophe Bouneau, David Burigana \& Antonio VARSORI (dir./eds.), 2010.

N 55 - L'OTAN et l'Europe. Quels liens pour la sécurité et la défense européenne? Birte WassenberG, Giovanni Faleg et Martin W. MlodeckI (dir.), 2010. 


\section{Euroclio European Network}

together with the SEGEI Network

Coordination : Chaire Jean Monnet d'histoire de l'Europe contemporaine (Cehec)

Collège Erasme, 1, place Blaise-Pascal, B-1348 Louvain-la-Neuve

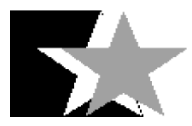

\section{Germany \\ Jürgen Elvert \\ Wilfried Loth}

\section{Belgium}

Julie Cailleau

Jocelyne Collonval

Yves Conrad

Gaëlle Courtois

Pascal Deloge

Geneviève Duchenne

Vincent Dujardin

Michel Dumoulin

Roch Hannecart

Pierre-Yves Plasman

Béatrice Roeh

Corine Schröder

Caroline Suzor

Pierre Tilly

Arthe Van Laer

Jérôme Wilson

Natacha Wittorski

\section{Spain}

Enrique Moradiellos

Mercedes Samaniego Boneu

\section{France}

Françoise Berger

Marie-Thérèse Bitsch

Gérard Bossuat

Éric Bussière

Jean-François Eck

Catherine Horel

Philippe Mioche

Marine Moguen-Toursel

Sylvain Schirmann

Matthieu Trouvé

Laurent Warlouzet

Emilie Willaert

\section{Hungary}

Gergely Fejérdy

\section{Italy}

David Burigana

Elena Calandri

Eleonora Guasconi

Luciano Segreto

Antonio Varsori

\section{Luxemburg}

Charles Barthel

Etienne Deschamps

Jean-Marie Kreins

René Leboutte

Robert Philippart

Corine Schröder

Gilbert Trausch

\section{The Netherlands}

Anjo Harryvan

Jan W. Brouwer

Jan van der Herst

\section{Poland}

Józef Laptos

Zdzisiaw Mach

\section{Switzerland}

Antoine Fleury

Lubor Jilek 
Discover the general website of the Peter Lang publishing group www.peterlang.com 